\title{
28. COMPARISON OF THE TAG MOUND AND STOCKWORK COMPLEX WITH CYPRUS-TYPE MASSIVE SULFIDE DEPOSITS ${ }^{1}$
}

\author{
Mark D. Hannington, ${ }^{2}$ Alan G. Galley, ${ }^{2}$ Peter M. Herzig, ${ }^{3}$ and Sven Petersen ${ }^{3}$
}

\begin{abstract}
Drilling of the active Trans-Atlantic Geotraverse (TAG) deposit indicates that the size of the mound-stockwork complex is approximately 3.9 million t, including 2.7 million t of massive and semi-massive sulfide $(2 \% \mathrm{Cu})$ at the seafloor and 1.2 million $\mathrm{t}$ of mineralized breccias $(\sim 1 \% \mathrm{Cu})$ in a subseafloor stockwork. Quartz-pyrite veining in the stockwork zone extends from about 40 meters below seafloor (mbsf) to a depth of $95 \mathrm{mbsf}$. Siliceous wallrock breccias in the lower part of the stockwork grade abruptly into chloritized basalt breccias at the margins of the mineralized zone, and massive sulfides at the flanks of the deposit onlap relatively unaltered, partially hematized basalts. The pipe-like dimensions of the stockwork zone do not exceed the diameter of the sulfide mound. Comparisons with samples collected during earlier dive series confirm that the vent complexes at the surface of the mound are not representative of the bulk composition of the deposit. Steep vertical metal zonation within the mound suggests that a long history of hydrothermal reworking has effectively stripped the constituents that are soluble at lower temperatures from the massive sulfides and concentrated them at the top of the deposit through a process of zone refining.

The bulk of the mound is composed of massive pyrite and anhydrite-cemented breccias. The massive anhydrite $(\sim 165,000$ t) occupies a high-temperature zone, immediately beneath the central Black Smoker Complex and above the quartz-rich stockwork. Fracturing in the underlying quartz-pyrite stockwork also has resulted in anhydrite veining at considerable depths in the stockwork zone. Despite the abundance of anhydrite in the mound, the amount of seawater penetrating the region of hightemperature upflow is small in comparison to the total mass flux of hydrothermal fluid. The anhydrite has been deposited by conductive heating of a small amount of entrained seawater at the margins of high-temperature conduits, and little or no mixing has occurred with the end-member fluids. Collapse of the anhydrite-supported portion of the mound following major episodes of hydrothermal upflow has caused extensive in situ brecciation of the mound and is an important mechanism for the formation of "breccia ores" in the deposit. Although anhydrite is not well preserved in the geologic record, given its retrograde solubility, it has likely played an important role in the development of similar ore types in ancient massive sulfides.

The morphology, size, and bulk composition of the TAG mound-stockwork complex is identical to that of some of the largest Cyprus-type massive sulfide deposits in the Troodos ophiolite. Typical Cyprus-type deposits comprise massive brecciated pyrite ores, underlain by a vertically extensive quartz-pyrite-chlorite stockwork. Sandy pyrite or conglomeratic ore, similar to that found in the TAG mound, is characteristic of the upper parts of Cyprus-type deposits. Textures in these ores, previously attributed to seafloor weathering and erosion, are most likely the result of anhydrite dissolution. Massive, granular pyrite (hard, compact ore), with abundant vuggy cavities lined by idiomorphic pyrite and quartz, occur below the conglomeratic ores and closely resemble sections of massive pyrite and pyrite-silica breccias from the TAG mound.

At TAG, seafloor oxidation of the sulfides is currently taking place, even as the deposit is forming. Fe-oxide gossans have developed at the surface of the mound as a result of weathering of chimney debris. These deposits are modern analogs of the extensive ochers that typically overlie the massive sulfide deposits in Cyprus. By analogy with TAG, a number of the weathering features of Cyprus-type deposits (e.g., red clays, leached lavas), previously thought to be products of acid alteration by meteoric groundwaters, may have formed while the deposits were still on the seafloor. Low-temperature venting through this material has locally produced distinctive red cherts (silicified Fe oxides). This material is common within the mound and in the underlying basalts and closely resembles the red jaspers found throughout the pillow lava sections in Cyprus. Silicification in the upper part of the TAG mound also has produced a cherty, sulfide carapace at the top of the deposit that inhibits further degradation of the mound by seafloor weathering. This may have important implications for the long-term preservation of the deposit, although dissection of the mound along active fault scarps may eventually expose its interior to seafloor oxidation.

An estimated growth rate for the TAG deposit, based on a total accumulation of 2.7 million t of massive sulfides and a cumulative venting history of 5 to $10 \mathrm{k} . \mathrm{y}$., is between 500 and 1,000 t per yr. This is consistent with observed growth rates for the central Black Smoker Complex and with estimates of mass fluxes from heat and fluid flow at black smoker vents on the East Pacific Rise. Although TAG is among the largest of the known mid-ocean ridge deposits, grade-tonnage models for Cyprus-type massive sulfides world-wide suggest that much larger deposits are likely forming elsewhere on the mid-ocean ridges and at similar, slow-spreading centers in extensional back-arc basins.
\end{abstract}

\section{INTRODUCTION}

Active hydrothermal vents and black smoker deposits on the midocean ridges are widely recognized as probable modern analogs of Cyprus-type massive sulfide deposits in ancient ophiolites (Table 1).

${ }^{1}$ Herzig, P.M., Humphris, S.E., Miller, D.J., and Zierenberg, R.A. (Eds.), 1998. Proc. ODP, Sci. Results, 158: College Station, TX (Ocean Drilling Program).

${ }^{2}$ Geological Survey of Canada, 601 Booth Street, Ottawa, Ontario K1A 0E8, Canada. markh@gsc.emr.ca

${ }^{3}$ Institut für Mineralogie, TU Bergakademie Freiberg, Brennhausgasse 14, 09596 Freiberg, Federal Republic of Germany.
The origin of Cyprus-type deposits at submarine hot springs has been widely accepted for at least 20 years (e.g., Hutchinson, 1965; Panayiotou, 1969; Constantinou, 1972, 1973; Constantinou and Govett, 1973; Searle, 1972), and more than a decade of seafloor research at active hydrothermal vents has not significantly changed the genetic models for these deposits. Most studies of ophiolite-hosted massive sulfides have included comparisons with active seafloor hydrothermal systems (e.g., Oudin, 1983; Oudin and Constantinou, 1984; Haymon et al., 1984; Ixer et al., 1984; Koski, 1987). However, comparisons with modern deposits have been limited by the fact that their subsurface morphology and composition are not well documented. Short of drilling an active sulfide deposit, direct observations of the 
Table 1. Grade and tonnage of selected ophiolite-hosted massive sulfide deposits in Cyprus and Oman.

\begin{tabular}{|c|c|c|c|c|c|c|c|c|}
\hline Deposit & Type & Tonnes (t) & $\mathrm{Cu}(\%)$ & $\mathrm{Zn}(\%)$ & $\mathrm{Pb}(\%)$ & $\mathrm{Ag}(\mathrm{ppm})$ & $\mathrm{Au}(\mathrm{ppm})$ & $\mathrm{S}(\%)$ \\
\hline TAG, Mid-Atlantic Ridge & & $3,800,000$ & 2.0 & 0.4 & $<0.01$ & 14 & 0.5 & 42 \\
\hline \multicolumn{9}{|l|}{ Troodos ophiolite, Cyprus } \\
\hline Limni & massive & 422,000 & 1.4 & - & - & 3 & 3.4 & - \\
\hline Limni & stockwork & $16,000,000$ & 1.0 & 0.2 & - & - & - & 14 \\
\hline Kinousa & reserves & $4,000,000$ & 1.5 & - & - & - & - & - \\
\hline Kinousa & massive \& stockwork & 300,000 & 2.4 & 3.4 & - & - & - & 44 \\
\hline Kinousa-Uncle Charles & massive \& stockwork & 220,000 & 2.2 & 1.0 & - & - & - & 47 \\
\hline Mavrovouni & - & $15,000,000$ & 3.8 & 0.5 & - & 39 & 0.3 & 49 \\
\hline Apliki & - & $1,650,000$ & 1.8 & 0.2 & - & 5 & - & 40 \\
\hline Skouriotissa & massive \& stockwork & $5,440,000$ & 2.3 & 0.06 & - & 69 & - & 48 \\
\hline Phoenix & stockwork & $15,000,000$ & 0.5 & - & - & - & - & - \\
\hline Ambelikou & - & 16,000 & 1.0 & - & - & - & - & 45 \\
\hline Memi & stockwork & $1,500,000$ & 0.1 & - & - & - & - & 26 \\
\hline Alestos & - & 100,000 & - & - & - & - & - & - \\
\hline Kokkinoyia & reserves & $1,000,000$ & 1.5 & 0.2 & - & - & - & 35 \\
\hline Kokkinoyia & massive \& stockwork & 500,000 & 3.8 & - & - & - & - & - \\
\hline Kokkinopezoula & massive \& stockwork & $3,500,000$ & 0.2 & - & - & - & - & 24 \\
\hline Agrokipia A & massive \& stockwork & 765,000 & 1.5 & 0.8 & - & - & - & 46 \\
\hline Agrokipia B & stockwork & $4,500,000$ & 0.4 & 0.06 & - & - & - & 35 \\
\hline Pitharokhoma & stockwork & $2,250,000$ & 0.5 & - & - & - & - & 20 \\
\hline Kambia & stockwork? & $1,500,000$ & - & - & - & - & - & 30 \\
\hline Kapedhes & - & 50,000 & 0.5 & - & - & - & - & - \\
\hline Mathiati & massive \& stockwork & $2,800,000$ & 0.2 & 1.0 & - & - & - & 33 \\
\hline Sha & massive \& stockwork & 350,000 & 1.0 & - & - & - & - & 25 \\
\hline Kalavasos-Mousoulos & massive \& stockwork & $6,916,000$ & 1.0 & 0.5 & 0.01 & 6 & 1.7 & 35 \\
\hline Platies & massive \& stockwork & 45,000 & 2.8 & - & - & - & - & 46 \\
\hline Klirou East & massive \& stockwork & 420,000 & 1.1 & 1.4 & - & - & - & 23 \\
\hline Klirou West & massive \& stockwork & 77,000 & 0.5 & 0.5 & - & - & - & 21 \\
\hline Troulli & - & 270,000 & 1.0 & - & - & - & - & 8 \\
\hline Peravasa & - & 90,000 & 0.8 & - & - & - & - & - \\
\hline \multicolumn{9}{|l|}{ Semail ophiolite, Oman } \\
\hline Aarja & massive \& stockwork & $3,200,000$ & 1.5 & 0.9 & 0.01 & - & - & - \\
\hline Byayda & massive \& stockwork & 900,000 & 3.1 & 1.4 & 0.01 & 11 & 1.2 & - \\
\hline Hyal-as-Safil & massive \& stockwork & $8,000,000$ & 1.3 & 0.6 & 0.01 & 10 & 0.6 & - \\
\hline Lasail & massive \& stockwork & $8,200,000$ & 2.1 & 0.04 & - & & & \\
\hline Rakah & massive \& stockwork & 400,000 & 7.7 & 1.2 & 0.04 & 25 & 19.0 & - \\
\hline
\end{tabular}

Notes: Sources are Bear (1963), Pantazis (1967), Kortan (1970), Constantinou (1980), Alabaster et al. (1980), Adamides (1984, 1987) Batchelor (1992). — = no information.

development of a large mound-stockwork complex have not been possible. Although the study of modern black smokers has enhanced the understanding of depositional processes at the seafloor, the growth of large deposits has been the subject of much speculation (e.g., Campbell et al., 1984).

In this paper, we compare the nature and distribution of the principal ore types in ophiolite-hosted massive sulfides in Cyprus and Oman with the results of drilling at Site 957. New evidence for the internal structure of large sulfide deposits on the modern seafloor provided by drilling at the Trans-Atlantic Geotraverse (TAG) site enhances current models for the genesis of Cyprus-type massive sulfides and suggests a reinterpretation of the origin of several important ore types. Several key observations, such as the role of anhydrite in the growth of the deposits, are a direct result of drilling an active sulfide mound.

\section{GEOLOGIC SETTING AND DESCRIPTION OF THE TAG DEPOSITS}

\section{TAG Hydrothermal Field}

The TAG hydrothermal field is a site of major active and fossil sulfide deposits in the rift valley and along the east wall of the MidAtlantic Ridge at $26^{\circ} \mathrm{N}$ (Fig. 1). Hydrothermal deposits consisting of active and relict sulfide mounds and $\mathrm{Fe}-\mathrm{Mn}$-oxides occur in an area of at least $5 \times 5 \mathrm{~km}$ at water depths ranging from 2300 to $4000 \mathrm{~m}$. Three main zones of sulfide deposits have been mapped, including the actively venting TAG mound and two fossil high-temperature vent fields known as the Mir zone and the Alvin zone (Rona et al., 1993a, 1993b). Low-temperature Fe-Mn-oxide deposits occur on top of the east wall between 2300 and $3100 \mathrm{~m}$ depth (Rona et al., 1986; Thompson et al., 1985).

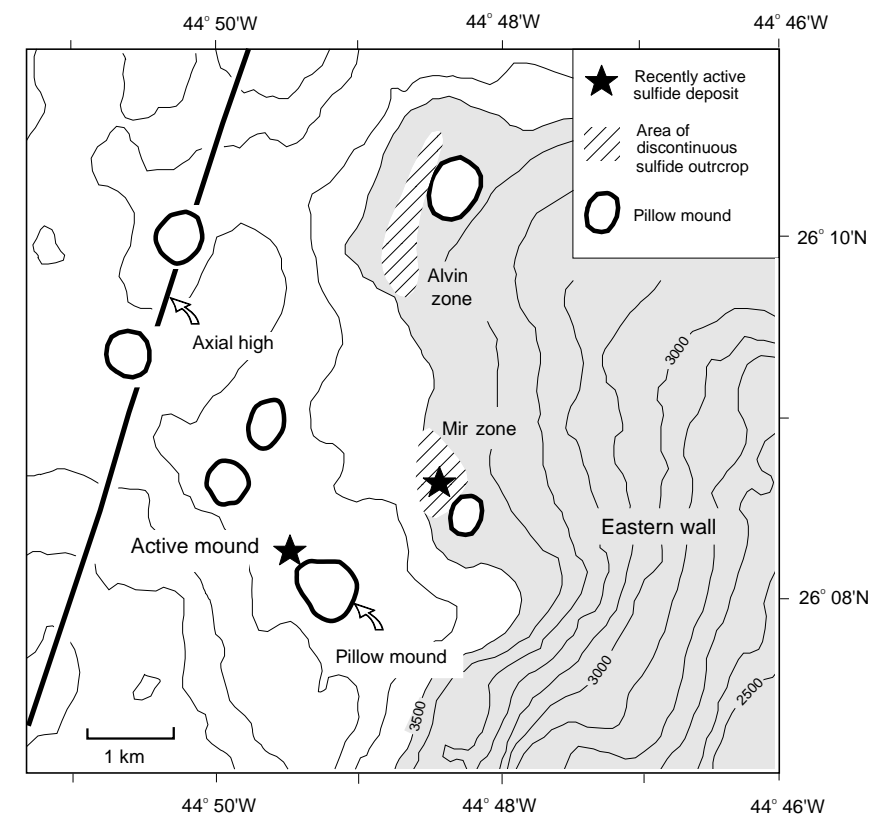

Figure 1. Location of sulfide deposits in the TAG hydrothermal field (modified from Rona et al., 1993a, 1993b). Contour intervals are $100 \mathrm{~m}$.

\section{Active TAG Mound}

The active TAG mound occurs on the floor of the rift valley at $3670 \mathrm{~m}$ depth, $2.4 \mathrm{~km}$ east of the axis and $1 \mathrm{~km}$ from the east wall. The deposit occurs in an area of numerous pillow volcanoes (e.g., 
Smith and Cann, 1990), and the massive sulfides partly overlap the northwest margin of a small pillow mound $(500 \mathrm{~m}$ wide and $35 \mathrm{~m}$ high: Zonenshain et al., 1989). The valley floor adjacent to the deposit is generally flat, although recently active, axis-parallel and transverse faults and fissures up to several meters wide occur in the pillow lavas and sediments surrounding the mound (Kleinrock et al., 1995). Hydrothermal upflow at TAG appears to be focused by the intersection of the axis-parallel fissures and a set of east-northeast-trending faults. Several graben-like depressions on the surface of the mound appear to be related to axis-parallel faults which bisect the eastern half of the deposit (Kleinrock et al., 1996). A major transverse fault system is also evident in the east wall of the rift valley adjacent to the TAG deposit (Karson and Rona, 1990), although its relationship to the vent field is not known. The local fissuring was likely an important factor in the development of numerous pillow volcanoes in the area, and the faults which have controlled hydrothermal upflow were probable conduits for dike intrusions feeding the nearby pillow mounds. Multiple episodes of hydrothermal venting at TAG during the past 50 k.y. may have been related to intrusive activity at several of these volcanic centers (Lalou et al., 1995).

\section{Mir Zone and Alvin Zone}

The Mir zone and Alvin zone are areas of discontinuous sulfide outcrop perched on fault blocks of the adjacent lower east wall, at water depths of 3400 and $3600 \mathrm{~m}$. As many as four discrete, relict sulfide mounds in the Mir and Alvin zones have been mapped, indicating an extensive earlier phase of hydrothermal activity in the area (up to $\sim 100 \mathrm{ka}$ ). The sulfide deposits are presently being dissected by faulting along the east wall and thereby have undergone extensive mass wasting.

The Mir zone is $\sim 2 \mathrm{~km}$ northeast of the active TAG mound and covers an area $\sim 1000 \mathrm{~m}$ long by $900 \mathrm{~m}$ wide. It consists of extensive sulfide outcrop interspersed with metalliferous sediment and Fe-Mnoxide staining. At the center of this zone is a large area of semicontinuous massive sulfide, measuring up to $600 \mathrm{~m}$ in strike length. The deposit appears to consist of a number of coalesced, relict sulfide mounds at different stages of weathering and mass wasting (Rona et al., 1993a, 1993b). Massive pyrite and chalcopyrite samples recovered from the Mir mound exhibit coarse-grained, recrystallized textures typical of hydrothermally reworked sulfide deposits on land. These ores are locally cut by late-stage, pyrite-sphalerite veins. The last high-temperature event on the Mir mound is estimated to have occurred about $10 \mathrm{ka}$. However, the presence of numerous small, standing chimneys in the center and at the margins of the field attests to a more recent stage of chimney growth superimposed on older sulfide material (e.g., Rona et al., 1993a, 1993b).

The Alvin zone, $3 \mathrm{~km}$ northeast of TAG, is similar in age and appearance to the Mir zone. It consists of a large area of discontinuous massive sulfide outcrop with a strike length of about $2000 \mathrm{~m}$. The area of sulfide outcrop is punctuated by several old, mound-like features approximately the same size as the active TAG mound (Rona et al., 1993a).

On the rift valley floor at the base of the east wall, local occurrences of metalliferous sulfide-oxide sediments have been recovered by short coring (e.g., Metz et al., 1987). Fragmental material within the cores was interpreted to have been eroded from decomposing massive sulfide deposits on the wall of the rift valley (possibly the Mir or Alvin zones) and deposited as sulfide-oxide turbidites on the valley floor.

\section{DESCRIPTION OF THE TAG MOUND AND STOCKWORK COMPLEX}

The TAG mound is a steep-sided structure measuring about 250 $\mathrm{m}$ in diameter and up to $40 \mathrm{~m}$ high (Fig. 2). Hydrothermal venting is centered on a 40- to 50-m-diameter Black Smoker Complex built on a conical edifice composed of anhydrite, pyrite, and chalcopyrite.
The black smokers are currently venting high-temperature fluids (up to $366^{\circ} \mathrm{C}$ ) from multiple spire-shaped chimneys up to $15 \mathrm{~m}$ in height. The Black Smoker Complex is surrounded by a raised platform up to $100 \mathrm{~m}$ wide, which is covered by debris from the collapse of sulfide chimneys (blocks ranging in size from tens of centimeters to several meters across). Large blocks of coarse-grained massive anhydrite, up to several meters, also occur at the base of the Black Smoker Complex. The anhydrite blocks contain abundant coarse-grained, disseminated pyrite and chalcopyrite that "weather" out of the anhydrite as it dissolves. The resulting pyrite- and chalcopyrite-rich sand forms an apron around the Black Smoker Complex.

A field of active and inactive white smoker chimneys, up to $2 \mathrm{~m}$ high, occurs close to the southeast margin of the mound (Kremlin area). The white smokers presently discharge fluids at temperatures of $265^{\circ}-300^{\circ} \mathrm{C}$ and appear to have grown on top of older sulfide debris during a recent phase of hydrothermal activity. The white smoker fluids are strongly depleted in most metals and sulfur compared to the black smokers, suggesting that mixing, conductive cooling, and precipitation of sulfides has occurred within the mound prior to venting (Edmond et al., 1995, Tivey et al., 1995). The distribution of vents across the TAG mound indicates a well-developed thermal profile with a central high-temperature upflow zone and a broader zone of cooler hydrothermal upflow at the margins of the deposit.

The sulfide talus on the surface of the mound is locally extensively oxidized, resulting in the formation of Fe-oxide gossans with minor secondary sulfides, jarosite, and atacamite (Thompson et al., 1988; Hannington et al., 1990a; Hannington, 1993). Samples of distinctive red chert recovered from the surface of the deposit are interpreted to be products of late-stage silicification of Fe-oxide sediments by low-temperature fluids leaking through the top of the mound (Hannington et al., 1990b; Tivey et al., 1995). In places, small, low-temperature chimneys have grown on top of this older, oxidized debris (cf. Kremlin area).

During the last $50 \mathrm{ka}$, accumulating sulfide talus on top of the mound has progressively been buried by the growth and collapse of new sulfide chimneys and gradually has become incorporated in the growing sulfide deposit. Diffuse, low-temperature venting through the talus occurs over much of the present surface, and the continuous flow of hydrothermal fluids through the sulfide debris has resulted in extensive hydrothermal recrystallization, annealing, and cementation of the chimney fragments. The substrate is poorly exposed beneath the sulfide talus, but local subcropping of massive pyrite sampled during earlier dive series provided important clues as to the bulk composition of the mound. These samples were composed of coarsegrained, recrystallized pyrite with little of the original chimney-like textures preserved.

The flanks of the deposit are steep-sided slopes, up to $20 \mathrm{~m}$ high, and are partially buried by an apron of sulfide debris and finegrained, Fe-oxide sediment. The debris is composed mainly of pyriterich blocks and pyritic sand eroded from sulfide outcrops along the escarpment at the edge of the mound. Fine-grained, detrital Fe oxides, eroded from the weathered slopes, have been deposited as microturbidites up to $60 \mathrm{~m}$ from the base of the mound (Hannington et al., 1990b; Mills et al., 1993). The Fe-oxide muds grade outward into pelagic ooze and form a bright red and brown halo surrounding the deposit. Close to the mound, the sediments appear to have been locally silicified, similar to the red cherts noted above. Angular basalt fragments found on the talus slopes were an early indication that the massive sulfides are underlain by a locally thickened section of pillow breccias (e.g., in situ talus or pillow mound: Lisitsyn et al., 1989).

\section{Surface of the TAG Mound}

More than 50 sulfide samples were previously collected from the TAG mound during 25 dives and by dredging from surface (Thompson et al., 1988; Rona et al., 1993a, 1993b; Tivey et al., 1995). The samples include black smoker chimneys, massive anhydrite, and 


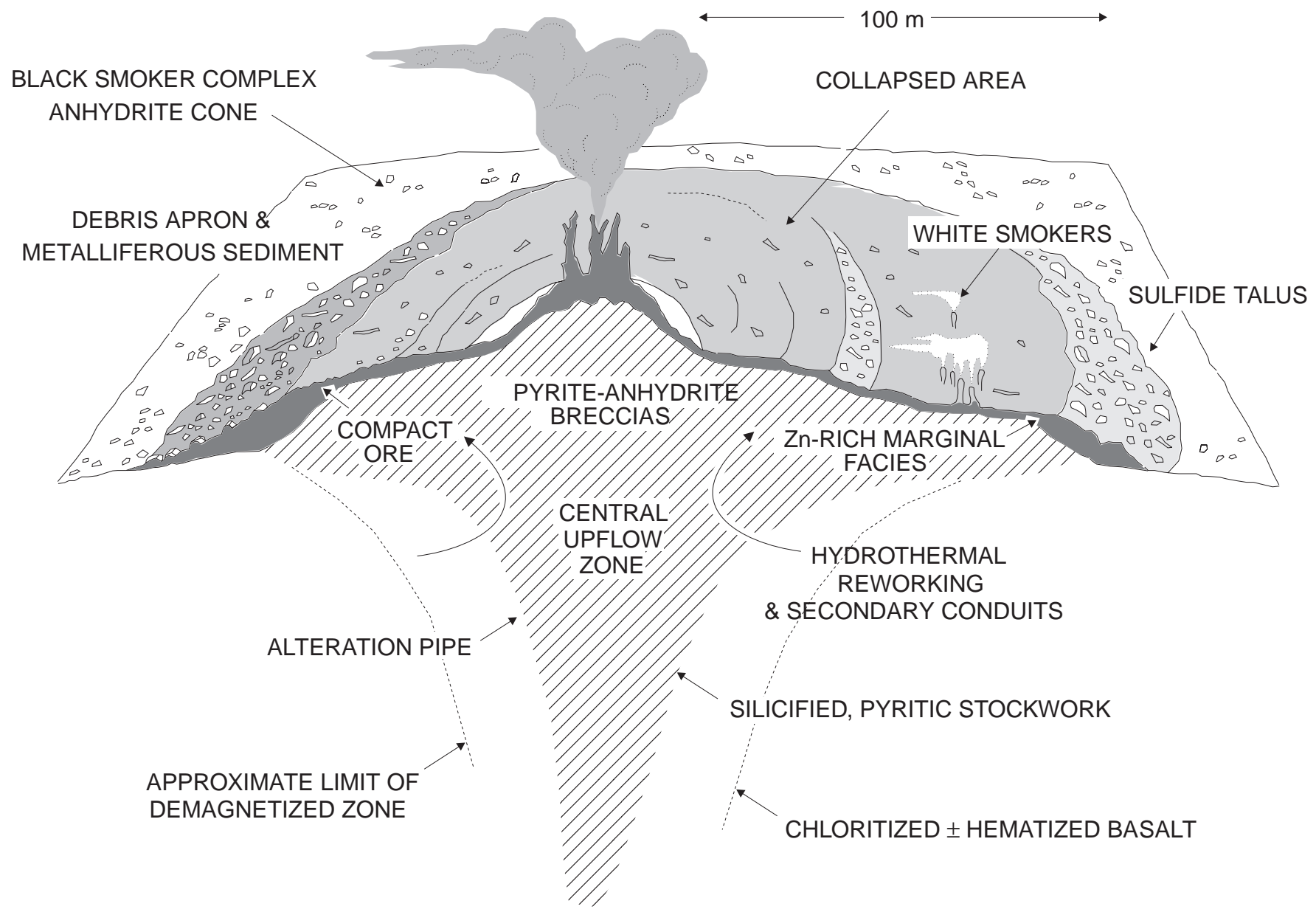

Figure 2. Schematic representation of the internal structure of the TAG mound. Most of the convective heat loss is accommodated by the central Black Smoker Complex. Diffuse venting of lower temperature fluids occurs through rubble at the surface of the mound. Fluids venting at white smokers in the Kremlin area are interpreted to have been transported away from the central upflow zone through secondary conduits leading to the outer margins of the deposit. Cooling of hydrothermal fluids at the margins of the upflow zone results in the precipitation of sulfides and silica within pyritic breccias on the flanks of the mound. Continuous hydrothermal reworking of pyritic breccias in the interior of the deposit has caused the $\mathrm{Zn}$ enrichment and associated low-temperature phases in a thin zone at the top of the deposit.

massive pyrite-chalcopyrite assemblages from the central Black Smoker Complex, lower temperature white smoker chimneys, and massive pyrite-sphalerite assemblages from sulfide talus on top of the mound. Delicate, primary banding, colloform textures, and dendritic sulfides are commonly preserved in these samples, confirming that much of the talus was derived from the recent collapse of sulfide chimneys. Samples from the central Black Smoker Complex consist mainly of pyrite, chalcopyrite, and anhydrite. Pyrrhotite is absent at TAG, and a primary assemblage of bornite-pyrite-chalcopyrite occurs locally. The white smokers are delicate, fine-grained structures, with bulk porosities up to $50 \mathrm{vol} \%$. These chimneys consist dominantly of fine-grained, dendritic, and colloform sphalerite together with minor marcasite and late-stage amorphous silica. Quartz, which is among the principal gangue minerals in the pyrite breccias in the interior of the mound, is largely absent in the surface samples, although some coarse-grained sulfide blocks contained minor amounts of euhedral quartz. A recent, detailed account of the mineralogy of the sulfides from the active mound is given by Tivey et al. (1995).

\section{Summary of the Drilling Results}

Seventeen holes were drilled at five locations on the surface of the TAG mound to a maximum depth of 125 meters below seafloor (mbsf; Humphris, Herzig, Miller, et al., 1996). A section through the mound, including the central Black Smoker Complex and the white smoker field is shown in Figure 3. The upper 5-10 $\mathrm{m}$ of the mound comprises mainly sulfide debris from collapsed chimneys, Fe-oxide gossan, and cherty sulfide breccias, capping massive pyrite and clastsupported pyrite breccias. From the surface to a depth of about $15 \mathrm{~m}$, the uppermost layers of massive sulfide consist of porous, colloform pyrite, pyrite breccias, and recrystallized massive pyrite \pm chalcopyrite. A hardened carapace of pyrite breccias that has been cemented by colloform pyrite and cherty silica occurs at the top of the deposit. In the center of the mound, below about $15 \mathrm{mbsf}$, the carapace of massive pyrite breccias and cherty sulfides is underlain by a $15-\mathrm{m}-$ thick section of anhydrite-cemented breccias, representing the root zone of the central Black Smoker Complex. The pyrite-anhydrite breccias extend to about $30 \mathrm{mbsf}$, where the anhydrite cement is gradually replaced by quartz at the top of the quartz-rich stockwork. Large anhydrite veins, which were first encountered about $20 \mathrm{mbsf}$, persist well below the anhydrite-rich zone to a depth of more than $45 \mathrm{mbsf}$. The largest veins reach nearly $45 \mathrm{~cm}$ in true thickness. Most of the holes through the upper part of the mound exhibited considerable instability, and nearly all were abandoned shortly after penetrating the stockwork because of the collapse of the overlying anhydrite-supported material. 


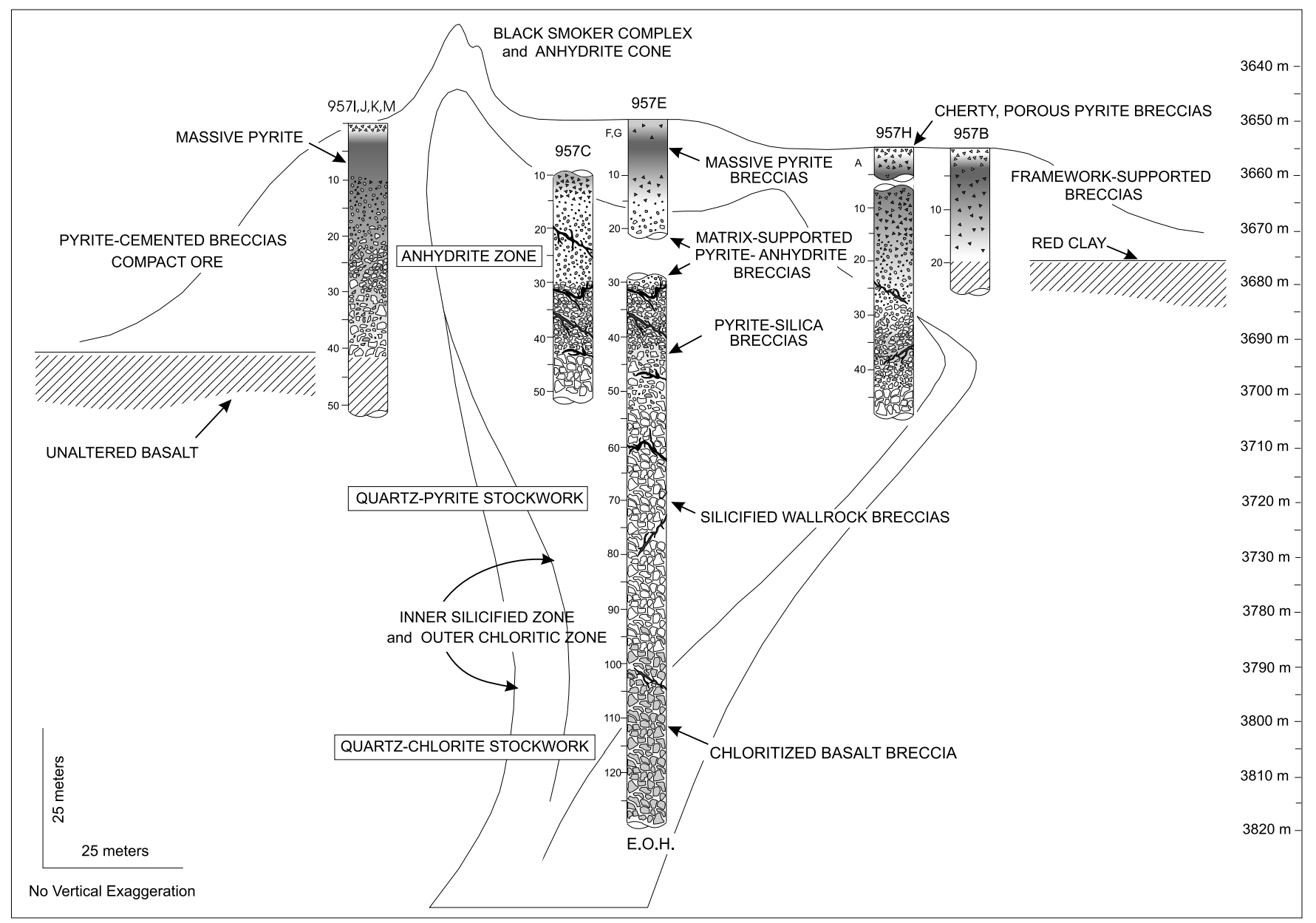

Figure 3. Interpreted structure of the TAG mound-stockwork complex based on results of drilling at Site 957. The section is from southeast to northwest, through the low-temperature Kremlin area and the central Black Smoker Complex. Recovery from the deepest hole that penetrated the stockwork zone indicates pervasive chloritization and pyritization of the basalts at depth. Intense alteration at the top of the upflow zone leads to silicification and complete replacement of the basalt breccias. Massive anhydrite and anhydrite-supported breccias occur above the quartz-pyrite stockwork and occupy the root zone of the central Black Smoker Complex. These zones are unlikely to have been part of a single prograde hydrothermal event and likely represent the products of many successive high-temperature hydrothermal events superimposed on an early mound-stockwork complex. The presence of a normal fault or series of fault steps beneath the mound is suggested by an apparent displacement of about $15-20 \mathrm{~m}$ on opposite sides of the mound. E.O.H. $=$ end of hole.

The thickness of the massive sulfides and anhydrite-supported breccias corresponds closely to the present relief of the mound ( $30-$ $40 \mathrm{~m})$. However, a pyrite-silica zone, consisting of quartz-cemented pyrite breccias, occurs immediately beneath the massive pyrite-anhydrite and extends well below the present seafloor between 30 and 45 mbsf. The pyrite-silica zone grades downward through a quartzpyrite stockwork and into intensely silicified and mineralized basalt breccias at greater depths. An abundance of silicified basalt fragments in the lower part of the pyrite-silica zone suggests that the bulk of the mineralization at this depth occupies a zone of partially to completely replaced pillow breccias. Between about 45 mbsf and 100 mbsf the quartz-rich stockwork contains abundant angular to subrounded clasts of silicified and intensely clay-altered basalt in a matrix of quartz and pyrite. Chlorite and clay alteration become most important ( $>10 \mathrm{vol} \%$ ) at a depth of about 90 mbsf.

The stockwork zone is a vertically extensive pipe-like feature, approximately $80-100 \mathrm{~m}$ in diameter at the top and roughly circular in plan. Relatively fresh basalt beneath the massive sulfides at the flanks of the deposit, indicates that the stockwork zone does not extend beyond the limit of the exposed sulfide mound. The massive sulfides and sulfide talus on the flanks of the deposit onlap relatively unaltered, partially hematized basalts, although there is locally a distinct layer of red clays of apparent hydrothermal origin at the sulfide/pillow lava contact. At the margins of the quartz-rich stockwork, and below about $100 \mathrm{mbsf}$, the silicified wallrock breccias grade abruptly into chloritized and locally hematized basalt breccias that are cut by minor quartz-pyrite veinlets and impregnated with minor disseminated pyrite.

The disposition of high-temperature vents at the surface of the mound and the absence of stockwork mineralization beneath the eastern half of the mound imply that the stockwork zone is asymmetric (e.g., Fig. 3). This is consistent with a fault-control that presently focuses hydrothermal upflow on the western side of the mound (i.e., hanging-wall side of the fault). A zone of demagnetization, approximately $80 \mathrm{~m}$ in diameter, occurs immediately beneath the central part of the mound and corresponds to the observed width of the upper part of the quartz stockwork (Tivey et al., 1993). The zone of demagnetization encompasses both the black and white smoker complexes and appears to straddle the structural/bathymetric discontinuity which is presently focusing hydrothermal upflow (Kleinrock et al., 1996). The occurrence of the uppermost wallrock breccias corresponds approximately to the position of the unaltered basalt substrate at the southeast flank of the mound, suggesting that the paleoseafloor beneath the central part of the mound is at a depth of about $30 \mathrm{~m}$, and is slightly 
deeper beneath the northwest margin of the mound. The displacement may be a result of a series of small step faults that could also account for the presence of less-altered basalt fragments locally higher within the stratigraphy. Although they are most abundant below 30 mbsf, the first basalt fragments were found at about $22 \mathrm{mbsf}$.

\section{Sulfide Types in the Mound-Stockwork Complex}

The sulfides recovered in drill core consist mainly of massive pyrite and pyritic breccias. Delicate, fine-grained textures typical of the original chimney morphologies are preserved only locally within the uppermost part of the mound. These features have been largely destroyed during hydrothermal recrystallization and replaced by coarser-grained pyrite. Veins of coarse pyrite, and locally sphalerite, are also found crosscutting earlier recrystallized sulfides, as in the samples from the Mir mound. A complex paragenesis is evident in the breccia ores through the entire deposit, including multiple generations of vein-filling, recrystallization, annealing, and cementation. Similar textures have been described in the exposed portions of other large, hydrothermally reworked sulfide deposits (e.g., Galapagos massive sulfides: Embley et al., 1988). In the interior of the mound, six main sulfide types compose the bulk of the mineralization: (1) cherty sulfide breccias, $(2)$ porous colloform pyrite ( \pm marcasite and minor sphalerite), (3) massive granular pyrite \pm chalcopyrite, (4) massive pyrite breccias, commonly in a sandy pyrite matrix, (5) pyrite-anhydrite breccias, and (6) pyrite-silica breccias. The different zones containing these ores are unlikely to have been part of a single prograde hydrothermal event and likely represent the products of many successive high-temperature hydrothermal events superimposed on an early mound-stockwork complex. A brief summary of the different breccia types follows. More detailed descriptions, together with representative photographs, can be found in Humphris, Herzig, Miller, et al. (1996) and elsewhere in this volume.

\section{Pyrite Breccias}

The sulfide breccias range in character from coarse, angular fragments of massive pyrite (up to $10 \mathrm{~cm}$ ) to nodular pyrite clasts in a sandy pyrite or anhydrite matrix. The breccias are variably framework to matrix-supported, and near the top of the mound they often contain little or no cementing material. The sandy pyrite in the uppermost breccias locally contains discrete clasts of chalcopyrite and closely resembles the detrital pyrite being "weathered out" of large anhydrite blocks at the base of the Black Smoker Complex. Massive pyrite, which underlies these breccias, ranges from densely-packed sulfide talus in a matrix of fine pyritic sand to recrystallized pyrite that has been cemented by colloform pyrite. In the upper part of the mound, this ore type also commonly contains minor colloform sphalerite, lining open cavities.

\section{Pyrite-Anhydrite Breccias}

Anhydrite-cemented pyrite breccias in the interior of the mound consist of angular to subrounded clasts or aggregates of pyrite in semi-massive anhydrite. Individual clasts are typically centimetersized, up to a maximum of about $10 \mathrm{~cm}$ (although this may reflect the size of clast recovered and not the actual size of breccia fragments in the mound). The cementing material ranges from pure anhydrite to porous, sandy pyrite-anhydrite mixtures and may account for up to 25 vol\% of the rock. Most of the pyrite is derived from pre-existing, brecciated massive sulfides, and individual pyrite clasts are often crosscut by later anhydrite veins. In the core of the mound, the brecciated pyrite is often distinctly nodular in appearance and the clasts exhibit extensively recrystallized outer rims. Large veins of anhydrite that crosscut the pyrite-anhydrite breccias commonly have distinctive halos of pyrite, and as much as $50 \%$ of the pyrite in some parts of the mound may have been precipitated during anhydrite veining.

\section{Pyrite-Silica Breccias and Quartz-Pyrite Stockwork}

The pyrite-silica breccias at the base of the anhydrite zone consist mainly of earlier pyrite-anhydrite breccias in which the anhydrite cement has been replaced by quartz. The breccias are locally veined by anhydrite, but anhydrite is not the dominant cementing material. At the top of the pyrite-silica zone, the breccias contain mainly clasts of pre-existing massive pyrite. Lower in this zone, many of the clasts are remnants of intensely silicified and pyritized wallrock, in which the breccia fragments have been almost completely replaced by quartz and pyrite. The brecciated wallrock consists mainly of gray siliceous material with abundant, fine-grained pyrite. Relict igneous textures are only rarely visible. Individual clasts are usually indistinct in core, but range in size from a few centimeters up to $10 \mathrm{~cm}$. At the base of the mound, the pyrite-silica breccias commonly incorporate a variety of earlier clast types (massive pyrite, red chert, less-altered basalt fragments), indicating multiple episodes of brecciation and collapse of the mound above the stockwork zone. Quartz-pyrite veining in the main stockwork zone becomes most important at a depth of about 50 mbsf. Many of the larger quartz veins appear to have originated as early pyrite-filled fractures that were re-opened and filled by later quartz during subsequent crack-seal events. Larger and more angular fragments of silicified wallrock and chloritized basalt occur in the lower portion of the quartz-pyrite stockwork. The chloritized basalt breccias at the bottom of the stockwork contain abundant networktype quartz and pyrite stringers and up to $20 \%$ disseminated pyrite. Fine-grained, disseminated pyrite also occurs at the outer limits of the chlorite pipe.

\section{Anhydrite Veins}

A complex network of anhydrite veins cuts the massive pyriteanhydrite breccias and underlying pyrite-silica breccias. The veins comprise mainly fine-grained, crystalline anhydrite and exhibit multiple generations of vein-fill and complex crosscutting relationships. The latest openings in the veins are often lined by chalcopyrite, indicating that the fractures were also conduits for high-temperature fluids. This is supported by fluid inclusion homogenization temperatures in the anhydrite, which are close to the exit temperatures of black smoker vents at the surface (e.g., Petersen et al., Chap. 13, this volume). The massive anhydrite blocks at the Black Smoker Complex also contain fluid inclusions that homogenize at high-temperatures (Fig. 4). Although anhydrite veining is found at the bottom of the deepest holes drilled, it is most abundant at the top of the quartzpyrite stockwork, and the amount of anhydrite veining decreases dramatically ( $<5$ vol\%) below about 50 mbsf.

\section{Mineralogy}

Pyrite in the TAG mound exhibits a wide range of textures, owing to extensive hydrothermal reworking, late-stage overgrowths, and recrystallization. The coarsest, euhedral pyrite occurs in the massive pyrite breccias and quartz-pyrite veins at the top of the stockwork zones. Grain sizes of 1-2 mm or larger in the massive pyrite are common and contrast sharply with the very fine-grained sulfides typical of most active chimneys (e.g., grains of less than a few hundred micrometers [Bluth and Ohmoto 1988; Paradis et al., 1988]). The pyrite typically exhibits a multi-stage crystallization history, with individual crystals displaying complex growth-zoning. Euhedral pyrite often contains inclusions or epitaxial growths of minor phases (quartz or chalcopyrite) between the growth bands. Colloform textures are best preserved in pyrite that cements the breccias at the top of the deposit or fills open cavities. Sphalerite occurs only in the uppermost part of the TAG deposit, filling open spaces and locally occupying late veins in the pyrite breccias. The sphalerite is generally Fe poor, in comparison to that of other seafloor deposits (e.g., Fig. 5) and is most likely related to a phase of low-temperature venting at the surface of the 
A.

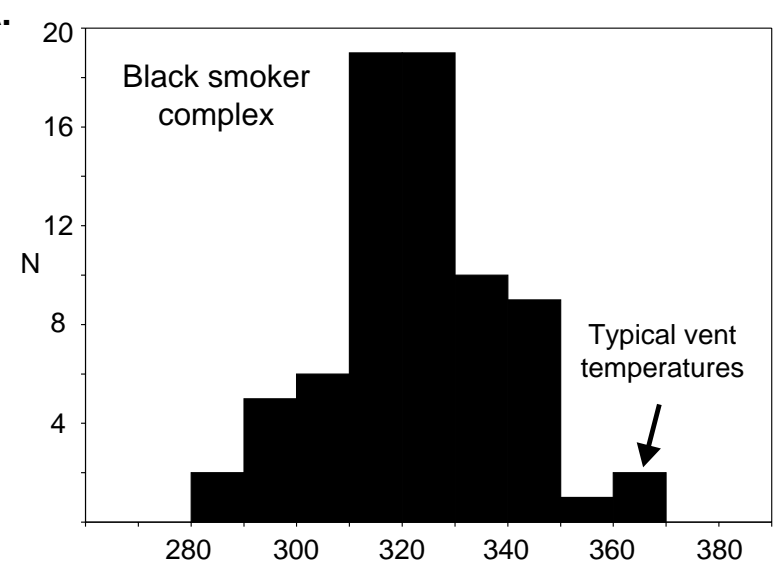

B.

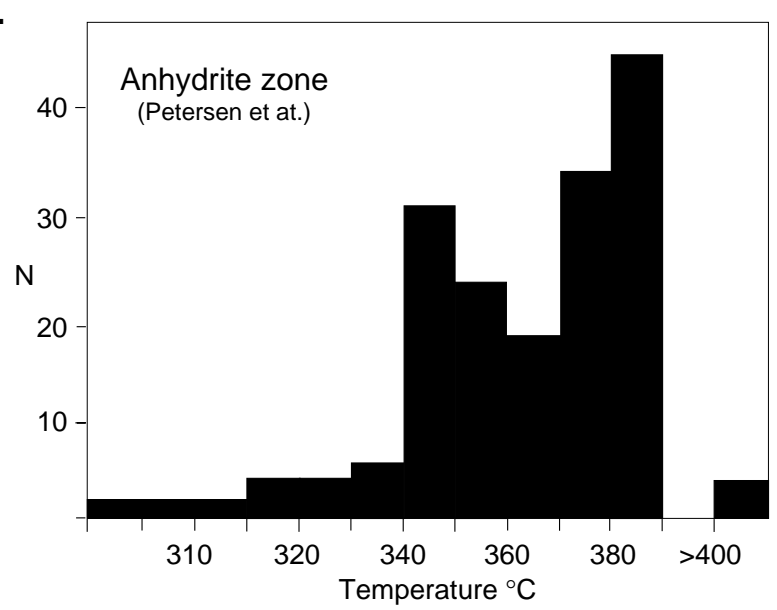

Figure 4. Fluid inclusions trapping temperatures in massive anhydrite from the central Black Smoker Complex (A) and from the anhydrite zone in the core of the TAG mound (B). Data are from Petersen et al. (Chap. 13, this volume) and Herzig and Hannington (unpubl. data). A mean trapping temperature of close to $350^{\circ} \mathrm{C}$ (corrected for 370 bars pressure) is indicated for fluid inclusions in anhydrite throughout the mound, confirming that the entrained seawater was heated uniformly to high temperatures in the upflow zone. $\mathrm{N}=$ number of analyses.

mound (e.g., Kremlin area: Tivey et al., 1995). Chalcopyrite is mainly intergrown with and locally replaces pyrite within the highest temperature part of the upflow zone and occurs locally within the most recent generation of quartz-pyrite and anhydrite veins. In some of the larger veins, chalcopyrite was likely deposited by fluids that were feeding high-temperature vents at the surface.

\section{Bulk Composition and Metal Zoning}

The bulk chemical analyses of the different ore types in the mound are summarized in Table 2 and the zonation of selected metals through the deposit is illustrated in Figure 6. The results of drilling indicate that the high $\mathrm{Cu}$ and $\mathrm{Zn}$ concentrations in samples collected at the surface of the mound are not representative of the bulk composition of the deposit. At the surface of the mound, high-temperature assemblages (e.g., typical of the Black Smoker Complex) are generally enriched in $\mathrm{Cu}, \mathrm{Co}$, and $\mathrm{Se}$, whereas lower temperature pyritesphalerite assemblages (e.g., typical of the white smokers) are notably enriched in $\mathrm{Zn}, \mathrm{Cd}, \mathrm{Au}, \mathrm{Ag}$, As, and Sb (Hannington et al., 1991; Rona et al., 1993a, 1993b; Tivey et al., 1995). Concentrations of these metals in the surface materials are nearly an order of magnitude
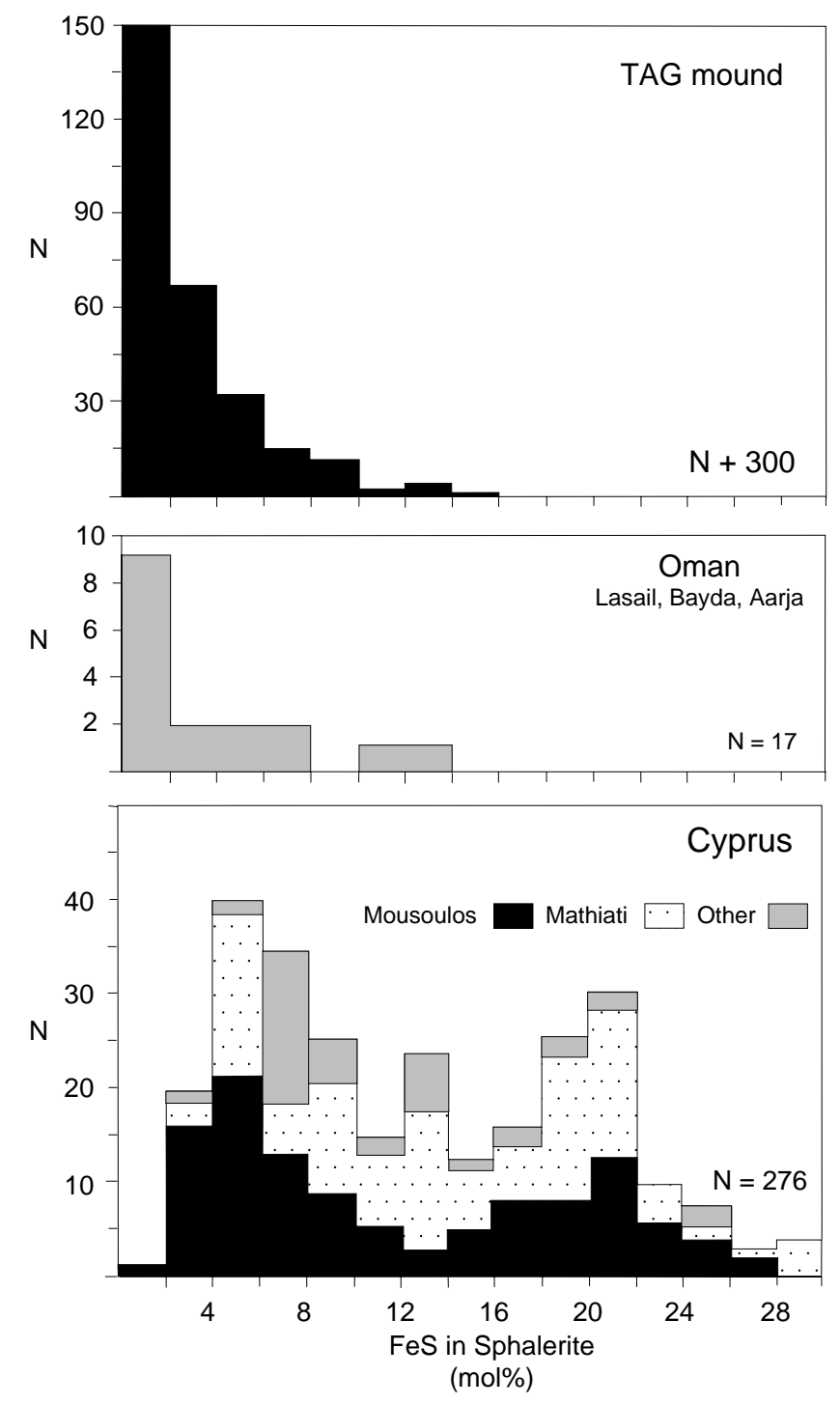

Figure 5. Compositions of sphalerite in samples from the TAG mound and from Cyprus-type massive sulfides in Oman and Cyprus. Data are from (Hannington and Scott, 1989; Tivey et al., 1995; Constantinou, 1972; Ixer et al., 1986). The bimodal distribution of sphalerite compositions in the Cyprus deposits may indicate the presence of both high- and low-temperature sphalerite. $\mathrm{N}=$ number of analyses.

higher than in the underlying pyrite breccias. A few samples of sphalerite-marcasite in the upper few meters of the mound resemble white smoker chimneys and possess high concentrations of $\mathrm{Au}, \mathrm{Ag}$, As, and Cd (Hannington et al., Chap. 2, this volume). The steep thermal gradients and extensive hydrothermal reworking of sulfides within the mound (i.e., zone refining) has resulted in the effective separation of $\mathrm{Zn}$ from higher-temperature assemblages immediately beneath the Black Smoker Complex and in the core of the deposit. Bulk $\mathrm{Cu} / \mathrm{Cu}+\mathrm{Zn}$ ratios in the surface material are generally less than 0.5, but are close to 0.9 throughout the rest of the deposit (i.e., similar to the deposits of Cyprus). The high grades of $\mathrm{Cu}$ and $\mathrm{Zn}$ in the surface samples represent relatively late stages of mineralization, with widespread overprinting of lower-temperature Zn-rich assemblages by later $\mathrm{Cu}$-rich sulfides and vice versa.

Despite the lower $\mathrm{Cu}$ and $\mathrm{Zn}$ contents, many of the pyrite breccias within the mound exhibit trace-element geochemistry similar to that of sulfides from the Black Smoker Complex, with elevated Co, Se, 


\begin{tabular}{|c|c|c|c|c|c|c|c|c|c|c|c|c|c|c|c|c|c|c|c|}
\hline & $\begin{array}{c}\text { Samples } \\
\text { (N) }\end{array}$ & $\mathrm{Cu}$ & $\mathrm{Fe}$ & $\mathrm{Zn}$ & $\mathrm{s}$ & $\mathrm{SiO}_{2}$ & $\mathrm{CaO}$ & $\mathrm{Al}_{2} \mathrm{O}_{3}$ & $\mathrm{Au}$ & $\mathrm{Ag}$ & As & Co & $\mathrm{Se}$ & Mo & $\mathrm{Ni}$ & $\mathrm{Cd}$ & $\mathrm{Sb}$ & $\mathrm{Pb}$ & Source \\
\hline $\begin{array}{l}\text { TAG, Alvin samples } \\
\text { Pyrite-sphalerite } \\
\text { Massive pyrite } \\
\text { Pyrite-chalcopyrite }\end{array}$ & $\begin{array}{l}23 \\
10 \\
17\end{array}$ & $\begin{array}{r}1.65 \\
4.61 \\
12.32\end{array}$ & $\begin{array}{l}13.5 \\
32.7 \\
21.8\end{array}$ & $\begin{array}{r}37.40 \\
3.34 \\
0.52\end{array}$ & $\begin{array}{l}32.3 \\
40.7 \\
27.5\end{array}$ & $\begin{array}{l}5.73 \\
3.29 \\
1.09\end{array}$ & $\begin{array}{r}3.60 \\
1.13 \\
13.02\end{array}$ & $\begin{array}{l}\bar{z} \\
\bar{z}\end{array}$ & $\begin{array}{r}5600 \\
1430 \\
560\end{array}$ & $\begin{array}{r}450 \\
37 \\
17\end{array}$ & $\begin{array}{l}80 \\
99 \\
37\end{array}$ & $\begin{array}{r}16 \\
258 \\
336\end{array}$ & $\begin{array}{r}1 \\
11 \\
177\end{array}$ & $\begin{array}{l}36 \\
94 \\
99\end{array}$ & $\begin{array}{l}44 \\
29 \\
30\end{array}$ & $\begin{array}{r}1170 \\
70 \\
15\end{array}$ & $\begin{array}{r}97 \\
9 \\
5\end{array}$ & $\begin{array}{r}550 \\
480 \\
89\end{array}$ & $\begin{array}{l}1 \\
1 \\
1\end{array}$ \\
\hline $\begin{array}{l}\text { TAG, Site } 957 \\
\text { Red and gray chert } \\
\text { Surface material ( }<5 \mathrm{mbsf})\end{array}$ & $\begin{array}{l}3 \\
6\end{array}$ & $\begin{array}{l}0.07 \\
6.09\end{array}$ & $\begin{array}{r}8.6 \\
21.9\end{array}$ & $\begin{array}{l}0.04 \\
1.61\end{array}$ & $\overline{32.9}$ & $\begin{array}{l}82.20 \\
37.80\end{array}$ & $\begin{array}{l}0.06 \\
0.71\end{array}$ & $\begin{array}{l}0.21 \\
0.27\end{array}$ & $\begin{array}{r}406 \\
1915\end{array}$ & $\begin{array}{r}9 \\
105\end{array}$ & $\begin{array}{l}12 \\
46\end{array}$ & $\begin{array}{l}24 \\
44\end{array}$ & $\begin{array}{r}<5 \\
5\end{array}$ & $\begin{array}{l}15 \\
44\end{array}$ & $\begin{array}{r}15 \\
<10\end{array}$ & $\begin{array}{l}<2 \\
59\end{array}$ & $\begin{array}{r}<1 \\
7\end{array}$ & $\begin{array}{r}39 \\
266\end{array}$ & $\begin{array}{l}2 \\
2\end{array}$ \\
\hline $\begin{array}{l}\text { Pyritic massive sultides } \\
\text { Massieve pyrite breccias } \\
\text { Pyrite-anydrite } \\
\text { Pyrite-silica-anhydrite }\end{array}$ & $\begin{array}{r}18 \\
6 \\
8\end{array}$ & $\begin{array}{l}2.11 \\
3.37 \\
4.70\end{array}$ & $\begin{array}{l}39.6 \\
30.2 \\
32.1\end{array}$ & $\begin{array}{l}0.79 \\
0.03 \\
0.15\end{array}$ & $\begin{array}{l}42.0 \\
44.6 \\
47.1\end{array}$ & $\begin{array}{l}2.83 \\
2.72 \\
3.68\end{array}$ & $\begin{array}{l}1.62 \\
9.47 \\
3.67\end{array}$ & $\begin{array}{l}0.13 \\
0.1 \\
0.18\end{array}$ & $\begin{array}{l}635 \\
163 \\
245\end{array}$ & $\begin{array}{l}8 \\
1 \\
3\end{array}$ & $\begin{array}{l}65 \\
39 \\
46\end{array}$ & $\begin{array}{l}204 \\
198 \\
180\end{array}$ & $\begin{array}{l}16 \\
21 \\
10\end{array}$ & $\begin{array}{l}86 \\
64 \\
83\end{array}$ & $\begin{array}{l}<10 \\
<10 \\
<10\end{array}$ & $\begin{array}{r}21 \\
<1 \\
4\end{array}$ & $\begin{array}{r}3 \\
<1 \\
1\end{array}$ & $\begin{array}{l}86 \\
25 \\
40\end{array}$ & $\begin{array}{l}2 \\
2\end{array}$ \\
\hline $\begin{array}{l}\text { Stockwork } \\
\text { Pyrite-silica breccias } \\
\text { Silicified wallrock breccia }\end{array}$ & $\begin{array}{r}12 \\
9\end{array}$ & $\begin{array}{l}1.92 \\
1.20\end{array}$ & $\begin{array}{l}28.6 \\
28.8\end{array}$ & $\begin{array}{l}0.10 \\
0.01\end{array}$ & $\begin{array}{l}36.6 \\
37.2\end{array}$ & $\begin{array}{l}27.70 \\
25.80\end{array}$ & $\begin{array}{l}1.51 \\
2.75\end{array}$ & $\begin{array}{l}0.34 \\
0.3\end{array}$ & $\begin{array}{r}214 \\
84\end{array}$ & $\begin{array}{l}<1 \\
<1\end{array}$ & $\begin{array}{l}33 \\
25\end{array}$ & $\begin{array}{l}285 \\
286\end{array}$ & $\begin{array}{l}17 \\
26\end{array}$ & $\begin{array}{l}61 \\
56\end{array}$ & $<10$ & $\begin{array}{r}3 \\
<1\end{array}$ & $<1$ & $\begin{array}{r}6 \\
18\end{array}$ & $\begin{array}{l}2 \\
2\end{array}$ \\
\hline $\begin{array}{l}\text { Cyprus, Troodos ophiolite } \\
\text { Pyritic massive sulfides }\end{array}$ & & & & & & & & & & & & & & & & & & & \\
\hline $\begin{array}{l}\text { Skouriotissa } \\
\text { Mathiati } \\
\text { Sha } \\
\text { Membi } \\
\text { Kambia } \\
\text { Kinousa-Uncle Charles } \\
\text { Agrokipia } \\
\text { Mavrovouni }\end{array}$ & $\begin{array}{r}8 \\
45 \\
1 \\
2 \\
1 \\
1 \\
2 \\
-\end{array}$ & $\begin{array}{r}2.78 \\
0.17 \\
1.90 \\
<0.01 \\
-0.18 \\
0.07 \\
3.69\end{array}$ & $\begin{array}{l}45.4 \\
39.5 \\
29.4 \\
42.0 \\
16.9 \\
42.5 \\
40.0 \\
39.2\end{array}$ & $\begin{array}{l}0.02 \\
0.26 \\
1.20 \\
0.02 \\
0<01 \\
0.02 \\
0.03 \\
0.80\end{array}$ & $\begin{array}{r}4 \overline{48.0} \\
36.7 \\
49.8 \\
51.5 \\
56.9\end{array}$ & $\begin{array}{r}3.78 \\
2.35 \\
25.00 \\
0.95 \\
0.98 \\
1.08 \\
3.70\end{array}$ & $\begin{array}{l}0.23 \\
0.49 \\
0.04 \\
0.19 \\
\overline{-0.03} \\
0.51 \\
-\end{array}$ & $\begin{array}{c}0.66 \\
<0.20 \\
0.3 \\
0.2 \\
0.22 \\
0.16 \\
2.44\end{array}$ & $\begin{array}{r}500 \\
800 \\
1000 \\
20 \\
40 \\
300 \\
135 \\
1050\end{array}$ & $\begin{array}{c}5 \\
4 \\
10 \\
0.9 \\
<5 \\
2 \\
1 \\
7\end{array}$ & $\begin{array}{r}74 \\
160 \\
657 \\
23 \\
70 \\
105 \\
201 \\
170\end{array}$ & $\begin{array}{r}359 \\
54 \\
20 \\
38 \\
40 \\
5 \\
190 \\
410\end{array}$ & $\begin{array}{r}296 \\
20 \\
26 \\
35 \\
<5 \\
5 \\
144 \\
330\end{array}$ & $\begin{array}{r}62 \\
35 \\
32 \\
2 \\
2 \\
8 \\
13 \\
10\end{array}$ & $\begin{array}{r}20 \\
33 \\
<10 \\
<10 \\
<10 \\
<10 \\
<-\end{array}$ & $\begin{array}{l}\overline{29} \\
27 \\
<1 \\
< \\
1 \\
1\end{array}$ & $\begin{array}{r}3 \\
11 \\
20 \\
<1 \\
3 \\
17 \\
3 \\
-\end{array}$ & $\begin{array}{r}<100 \\
97 \\
94 \\
2 \\
19 \\
30 \\
-\end{array}$ & $\begin{array}{r}3,4 \\
3,5 \\
3 \\
3 \\
3 \\
3 \\
3 \\
4\end{array}$ \\
\hline $\begin{array}{l}\text { Stockwork } \\
\text { Agrokipia B }\end{array}$ & 30 & 0.04 & 45.5 & 0.05 & 19.0 & - & - & - & 160 & $<5$ & 694 & 133 & 7 & 5 & 36 & 14 & - & - & $5,6,7$ \\
\hline $\begin{array}{l}\text { Oman, Semail ophiolite } \\
\text { Pyritic massive sulfides } \\
\text { Lasail } \\
\text { Bayda } \\
\text { Aaria } \\
\text { Al Ajal } \\
\text { Hayal-as-Safil } \\
\text { Rakah }\end{array}$ & $\begin{array}{l}4 \\
2 \\
3 \\
3 \\
2 \\
3\end{array}$ & $\begin{array}{l}3.75 \\
\overline{5.82} \\
0.71 \\
2.29 \\
7.70\end{array}$ & $\begin{array}{l}47.1 \\
44.2 \\
26.8 \\
54.7 \\
43.4 \\
43.7\end{array}$ & $\begin{array}{l}0.05 \\
0.92 \\
0.05 \\
0.96 \\
0.12 \\
1.19\end{array}$ & $\begin{array}{l}= \\
= \\
= \\
=\end{array}$ & $\begin{array}{r}5.88 \\
36.40 \\
80.67 \\
20.50 \\
13.00\end{array}$ & $\begin{array}{l}0.78 \\
0.26 \\
0.59 \\
1.20 \\
-\end{array}$ & $\begin{array}{l}2.65 \\
2.43 \\
1.56 \\
1.5 \\
9 \\
3\end{array}$ & $\begin{array}{l}= \\
= \\
= \\
=\end{array}$ & $\begin{array}{l}\frac{8}{13} \\
19 \\
10 \\
25\end{array}$ & $\begin{array}{r}70 \\
60 \\
280 \\
206 \\
86 \\
5100\end{array}$ & $\begin{array}{r}235 \\
135 \\
80 \\
362 \\
630 \\
256\end{array}$ & $\begin{array}{l}\bar{z} \\
\bar{z} \\
=\end{array}$ & $\begin{array}{r}15 \\
125 \\
10 \\
- \\
-\end{array}$ & $\begin{array}{l}75 \\
25 \\
45 \\
42 \\
40 \\
80\end{array}$ & $\begin{array}{r}\overline{5} \\
185 \\
= \\
=\end{array}$ & $\begin{array}{l}- \\
\bar{Z} \\
<5 \\
<5 \\
199\end{array}$ & $\begin{array}{r}25 \\
60 \\
145 \\
223 \\
60 \\
423\end{array}$ & $\begin{array}{l}8 \\
8 \\
8 \\
9 \\
9 \\
9\end{array}$ \\
\hline $\begin{array}{l}\text { Stockwork } \\
\text { Bayda } \\
\text { Al Ajal } \\
\text { Hayal-as-Safil } \\
\text { Rakah }\end{array}$ & $\begin{array}{l}4 \\
3 \\
1 \\
4\end{array}$ & $\begin{array}{l}2.65 \\
0.97 \\
0.34 \\
>1.5\end{array}$ & $\begin{array}{r}32.5 \\
17.8 \\
9.4 \\
21.7\end{array}$ & $\begin{array}{l}0.29 \\
0.07 \\
0.02 \\
0.29\end{array}$ & $\begin{array}{l}\bar{z} \\
\bar{z}\end{array}$ & $\begin{array}{l}24.10 \\
49.00 \\
58.00 \\
41.25\end{array}$ & $\begin{array}{l}\bar{z} \\
\bar{z}\end{array}$ & $\begin{array}{c}1.52 \\
15 \\
9.5 \\
10.25\end{array}$ & $\begin{array}{l}\bar{z} \\
\bar{z}\end{array}$ & $\begin{array}{l}\overline{<1} \\
<1 \\
2\end{array}$ & $\begin{array}{r}50 \\
36 \\
11 \\
245\end{array}$ & $\begin{array}{r}130 \\
180 \\
62 \\
130\end{array}$ & $\begin{array}{l}\bar{z} \\
\bar{z}\end{array}$ & $\begin{array}{l}\frac{32}{z} \\
-\end{array}$ & $\begin{array}{r}33 \\
117 \\
149 \\
110\end{array}$ & $\begin{array}{l}\bar{z} \\
\bar{z}\end{array}$ & $\begin{array}{r}\overline{<5} \\
<5 \\
5\end{array}$ & $\begin{array}{r}61 \\
10 \\
8 \\
27\end{array}$ & $\begin{array}{l}8 \\
9 \\
9 \\
9\end{array}$ \\
\hline
\end{tabular}

Note: Sources: 1 = Hannington et al. (1991), Tivey et al. (1995); 2 = Hannington et al. (this volume); 3 = this study; $4=$ Kortan (1970); $5=$ Constantinou and Govett (1973); $6=$ Herzig (1988), $7=$ Hannington et al. (1990); $8=$ Inxer et al (1984), Ixer et al. (1986); 9 = Lescuyer et al. (1988). 


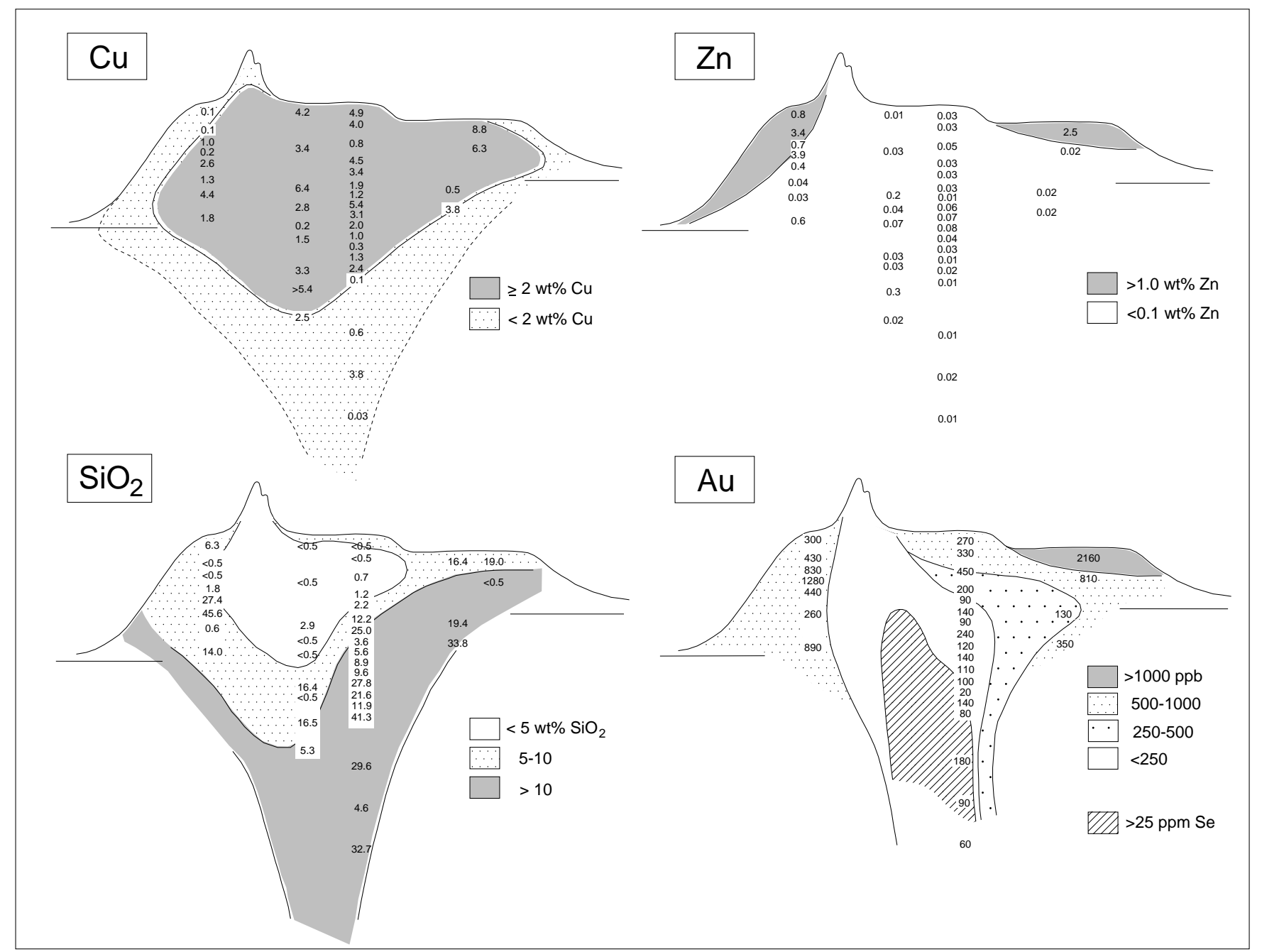

Figure 6. Schematic representation of metal zonation in the TAG mound-stockwork complex. Results of bulk chemical analyses from the different holes are projected onto the southeast-northwest section through the low-temperature white smokers and central Black Smoker Complex. Data are from Hannington et al. (Chap. 2, this volume).

and Mo. In general, $\mathrm{Co}$ and $\mathrm{Se}$ exhibit a positive correlation with $\mathrm{Cu}$ (e.g., Fig. 7), consistent with the enrichment of these elements in the highest-temperature sulfides of other seafloor deposits (e.g., Auclair et al., 1987; Hannington et al., 1991). Concentrates of pyrite and chalcopyrite in the anhydrite veins at depth in the mound are notably enriched in Co (up to $1200 \mathrm{ppm}$ ) and to a lesser extent Se (up to 140 ppm), Ni (up to 500 ppm), and Mo (up to 200 ppm; Hannington et al., Chap. 2, this volume). Although these concentrations are substantially higher than for other trace elements, overall there is a depletion of trace metals in the interior of the mound, similar to that observed for $\mathrm{Cu}$ and $\mathrm{Zn}$. Low-temperature constituents such as $\mathrm{Ag}, \mathrm{Au}$, and $\mathrm{Sb}$ are nearly quantitatively removed from the massive sulfides. The very high concentrations of $\mathrm{Ag}$ and $\mathrm{Au}$ in the white smokers confirm that these elements are continuously remobilized to the surface during prograde hydrothermal events (Hannington et al., 1995b). Arsenic concentrations are less affected, owing to the strong partitioning of As into the pyrite structure.

\section{Grade and Tonnage Calculations}

One of the principal objectives of Leg 158 was to determine the size of the TAG sulfide deposit. The volcanic substrate was intersect- ed in four of the five areas drilled, and the vertical extent of the stockwork mineralization was established in two of the areas (Fig. 3). Based on the core recovered $(10 \%-15 \%)$ and bulk chemical analyses of 60 representative samples, an average grade and total tonnage for the deposit was calculated using a simplified block model of the mound (Fig. 8). A summary of the results is given in Table 3, and details of the calculations using the block model are given in Tables 4 and 5 .

The total mass of the deposit is estimated to be 3.9 million $\mathrm{t}$, with the exposed sulfide mound accounting for about $70 \%$ of the total $(2.7$ million $\mathrm{t}$ ) and the underlying stockwork zone accounting for the remainder (1.2 million $t)$. The deposit is estimated to contain about 2.3 million t of pyrite. The central Black Smoker Complex (about $40 \mathrm{~m}$ in diameter and $40 \mathrm{~m}$ in height) contains $16,750 \mathrm{~m}^{3}$ of massive anhydrite or between 30,000 and 50,000 t. The anhydrite zone in the core of the mound is estimated to contain an additional 165,000 $t$ of anhydrite.

Average $\mathrm{Cu}$ grades in the massive sulfide section of the mound average close to $2.8 \mathrm{wt} \%$ (Table 5, but a large range in $\mathrm{Cu}$ concentrations is apparent in the samples analyzed. A bias toward sampling of sulfide-rich sections of the drill core is indicated by a $30 \%$ discrepancy between visual estimates of the pyrite content in the whole core 

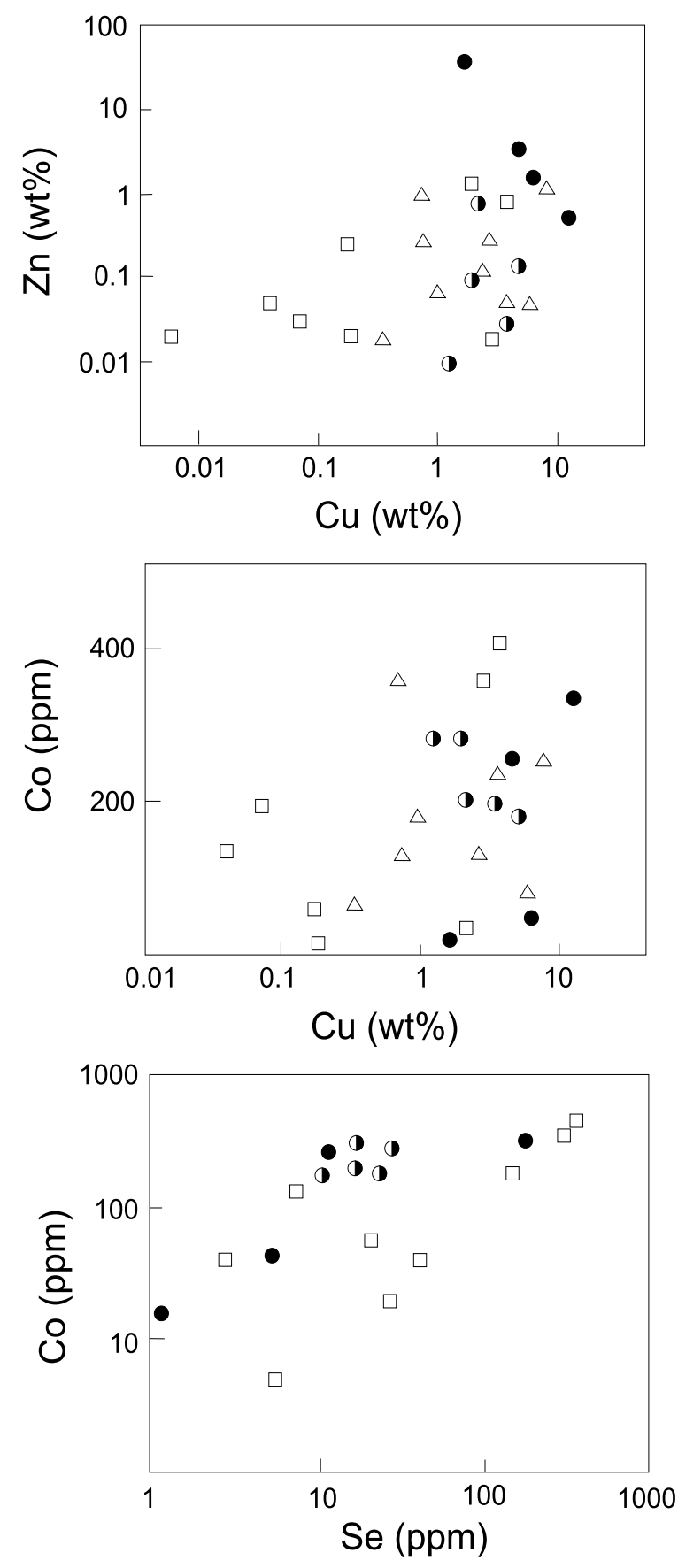

Figure 7. Comparison of bulk $\mathrm{Cu}, \mathrm{Zn}, \mathrm{Co}$, and Se contents in the ores from the TAG mound and similar deposits in Cyprus and Oman. Data are from Table 2 (solid circles = surface samples from the TAG mound; half-solid circles $=$ breccias from the TAG mound-stockwork complex; squares $=$ average values for Cyprus deposits; triangles $=$ average values for Oman deposits).

and the measured sulfur content in subsamples taken for shipboard analyses (Tables 4 and 5). This is especially apparent in the anhydrite-rich zone and quartz-rich stockwork. Sufficient sampling of the core to establish a coherent grade distribution was not possible, but a reasonable estimate for the deposit based on a $30 \%$ dilution would be close to $2 \mathrm{wt} \%$. Logging of the drill core indicates greater dilution in the lower part of the mound-stockwork complex, and the bulk $\mathrm{Cu}$ grades are estimated to be $50 \%$ lower in the quartz-pyrite and quartzchlorite zones. Based on these observations, a conservative estimate of the bulk $\mathrm{Cu}$ content of the deposit is between 30,000 and 60,000 t of $\mathrm{Cu}$ metal (Table 3). The actual sulfide ores, following the removal of anhydrite, would have bulk compositions close to those listed in Table 5, with a total sulfur content of about $42 \mathrm{wt} \%$ for the deposit (i.e., close to that of many Cyprus-type massive sulfides).

\section{DEPOSITS IN ANCIENT OPHIOLITES}

As many as 200 ophiolite sequences are preserved in the geologic record world-wide (e.g., Nicolas, 1995), and these contain at least 50 major producing mines. The ophiolite settings are comparable to modern oceanic spreading centers, although there is some debate about whether they represent mid-ocean ridges or suprasubduction in extensional back-arc basins (Miyashiro 1973; Coleman, 1981; Pearce et al., 1981; Hawkins et al., 1984; Cameron, 1985). Among the bestexposed and least-deformed massive sulfides in ancient ophiolites occur in Cyprus and Oman. These rocks mark the suture zone along which the Tethys Ocean closed at the end of the Cretaceous. Most of the massive sulfides are associated with large-scale fault systems, which suggests that spreading-axis morphologies at the time of mineralization were controlled by tectonic extension rather than magmatism (e.g., similar to the Mid-Atlantic Ridge: Varga and Moores, 1985; Kappel and Franklin, 1989; Harper, 1985). A number of deposits, such as those in Oman are thought to have formed on off-axis seamounts (Alabaster et al., 1980).

\section{Troodos Ophiolite, Cyprus}

The Troodos ophiolite comprises the Troodos plutonic complex, a thick sheeted intrusive complex, and the Troodos pillow lavas (Fig. 9). The volcanic rocks are capped by the sedimentary Perapedhi Formation, which contains abundant Fe-Mn oxide sediments and is overlain by Tertiary marls and limestones. The massive sulfides are located throughout the basaltic section, from the sheeted dikes to the upper pillow lavas. The largest deposits (both in Cyprus and Oman) occur between major pillow sequences of slightly different composition (i.e., likely deposited during a hiatus between separate magmatic episodes: Constantinou, 1980; Alabaster et al., 1980).

The deposits in Cyprus are clustered in 5 mining districts: Limni, Kalavasos-Mousoulos, Skouriotissa-Mavrovouni, Mitsero (Agrokipia), and Tamassos (Mathiati-Sha), each occupying an area of approximately $10 \times 10 \mathrm{~km}$. The major districts correspond to the locations of several fossil, axial graben structures (e.g., Constantinou, 1980; Varga and Moores, 1985). A typical mining lease $(2 \times 2 \mathrm{~km})$ contains at least 30 developed prospects and up to 20 million $\mathrm{t}$ of massive sulfides (e.g., Kalavasos-Mousoulos: Adamides, 1980).

Mining of copper from the near-surface exposures has persisted since 4000 B.C. (Hadjistavrinou and Constantinou, 1982). Early mining was exclusively for $\mathrm{Cu}$ and $\mathrm{Au}$, although the deposits have been exploited more recently for $\mathrm{S}$. The bulk of the ore was cupriferous pyrite, but the average grades of ore mined were typically less than 2 $\mathrm{wt} \% \mathrm{Cu}$ and only rarely exceeded $4 \mathrm{wt} \% \mathrm{Cu}$ (Table 1). Sphaleriterich ores, although present, were generally not mined. Zinc was not a useful commodity during the early mining history of Cyprus, and this material was left as waste. As a result, historical records of mining often did not account for the $\mathrm{Zn}$-rich ores, and $\mathrm{Zn}$ grades for many $\mathrm{Cy}$ prus-type massive sulfides are either understated or not reported at all. Massive and semi-massive zones of sphalerite ore are well documented in more recently developed prospects at Sha and Kinousa (Adamides, 1987), and this ore-type is common in the deposits currently being mined in Oman (e.g., Table 1).

The mineable deposits range in size from 50,000 t up to 16 million $\mathrm{t}$ (Table 1), but there are many smaller, undeveloped prospects. Most of the past production of $\mathrm{Cu}$ was from just a few of the largest depos- 


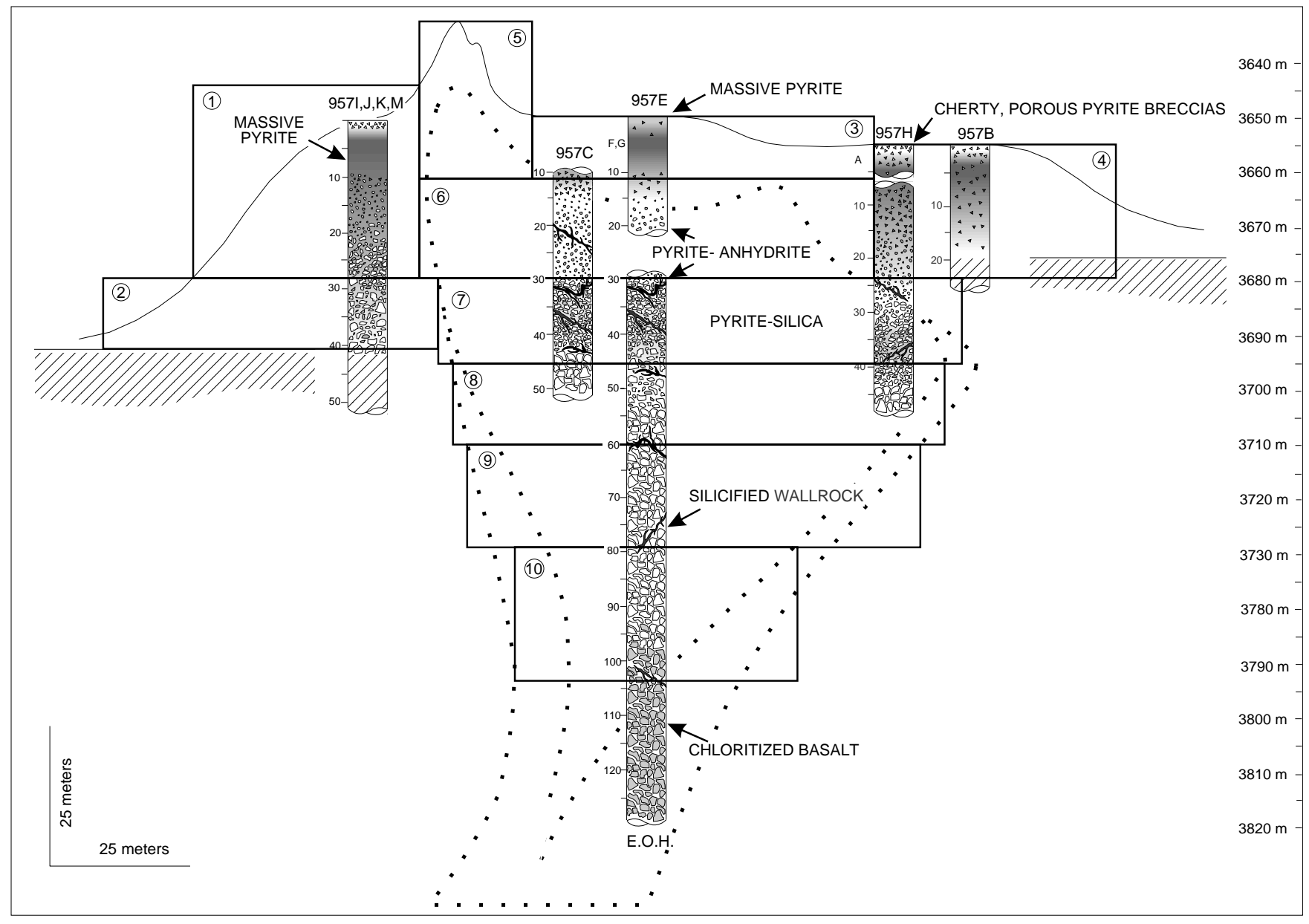

Figure 8. Block model of the TAG mound-stockwork complex showing the location of blocks used to calculate the bulk tonnage of the deposit. The volumes were calculated by rotating each block as a cylinder around the center of the deposit. Blocks 1, 2, and 4 were calculated as annular zones surrounding the deposit.

Table 3. Dimensions of the TAG mound-stockwork complex: summary of the block model.

\begin{tabular}{llcc}
\hline \multicolumn{1}{c}{ Dimension } & \multicolumn{1}{c}{ Blocks } & $\begin{array}{c}\text { Volume } \\
\left(\mathrm{m}^{3}\right)\end{array}$ & $\begin{array}{c}\text { Calculated } \\
\text { Tonnage }(\mathrm{t})\end{array}$ \\
\hline Total size of deposit & Blocks 1-10 & $1,031,300$ & $3,885,600$ \\
Exposed mound of massive sulfides* & Blocks 1-6 & 701,163 & $2,695,000$ \\
Subseafloor stockwork mineralization & Blocks 7-10 & 330,160 & $1,190,900$ \\
Total pyrite content & Blocks 1-10 & - & $2,30,400$ \\
Total Cu & $1-2 \%$ Cu in blocks 1-10 & - & $30,000-60,000$ \\
Anhydrite zone & 50\% anhydrite in blocks 5,6 & 109,950 & 329,860 \\
\hline
\end{tabular}

Note: $*$ = to a depth of $20-25 \mathrm{~m}$.

its (Mavrovouni, Limni, Skouriotissa). Only about 50\% were larger than 1 million $\mathrm{t}$, and fewer than $15 \%$ were larger than 10 million $\mathrm{t}$. This is typical of many base metal mining camps, in which the single largest deposit may contain $60 \%-70 \%$ of the total metal reserves for that district (e.g., the second largest deposit may contain only $10 \%-$ 20\%: Sangster, 1980). However, the statistics are obviously biased by the fact that recorded tonnages refer only to the deposits of sufficient size and grade to be mined. In Cyprus, vast numbers of smaller sulfide occurrences were not important enough to be included in published reserves. These included more than 90 undeveloped prospects with less than $100,000 \mathrm{t}$ each, similar to those on the modern midocean ridges.

\section{Comparison of Ophiolite-Hosted Deposits in Cyprus and the TAG Mound-Stockwork Complex}

Most of the ore in the massive sulfide deposits in Cyprus is mined from a zone of massive pyrite deposited as a central mound on the paleoseafloor-seafloor and from the immediately adjacent stockwork zone (Fig. 10). The deposits typically lie on an intensely altered and brecciated substrate containing abundant sulfide veins and disseminated pyrite. The quartz-pyrite stockworks occur beneath the highestgrade portions of the deposits, and a significant proportion of the recoverable base metals usually occurs as stockwork mineralization and replacement ores beneath the seafloor. Some of the largest depos- 
Table 4. Block model of the TAG sulfide deposit.

\begin{tabular}{cclcrrrr}
\hline Block \# & Dimensions & \multicolumn{1}{c}{ Rock type } & Density & $\begin{array}{r}\text { Pyrite } \\
(\mathrm{vol} \%)\end{array}$ & $\begin{array}{r}\text { Volume } \\
\left(\mathrm{m}^{3}\right)\end{array}$ & $\begin{array}{c}\text { T Tonnes } \\
(\mathrm{t})\end{array}$ & \multicolumn{1}{c}{$\begin{array}{c}\text { Pyrite } \\
(\mathrm{t})\end{array}$} \\
\hline & & & & & & & \\
1 & $40 \times 35$ & Massive pyrite & 4 & 80 & 87,970 & 351,860 & 281,500 \\
2 & $60 \times 15$ & Semi-masive pyrite & 4 & 60 & 226,200 & 904,780 & 542,870 \\
3 & $70 \times 10$ & Massive pyrite & 4 & 80 & 38,480 & 153,940 & 123,150 \\
4 & $45 \times 25$ & Massive pyrite & 4 & 80 & 238,570 & 954,260 & 763,410 \\
5 & $20 \times 30$ & Anhydrite zone & 3 & $<50$ & 9,420 & 28,270 & 14,140 \\
6 & $80 \times 20$ & Anhydrite zone & 3 & $<50$ & 100,530 & 301,590 & 150,800 \\
7 & $90 \times 15$ & Pyrite-silica & 3.75 & 50 & 95,430 & 357,850 & 178,930 \\
8 & $85 \times 15$ & Silicified wallrock & 3.75 & 40 & 85,120 & 319,190 & 127,680 \\
9 & $80 \times 20$ & Silicified wallrock & 3.5 & 30 & 100,530 & 351,860 & 105,560 \\
10 & $50 \times 25$ & Quartz-chlorite & 3.5 & 20 & 49,090 & 161,990 & 32,400 \\
& & & & & $1,031,340$ & $3,885,590$ & $2,320,440$ \\
\hline
\end{tabular}

Note: Density is based on shipboard estimates (Humphris, Herzig, Miller, et al., 1996); pyrite (vol\%) lists visual estimates of pyrite content in drill core.

Table 5. Average bulk composition of samples in the block model of the TAG mound-stockwork complex.

\begin{tabular}{cccccccccc}
\hline Block \# & $\begin{array}{c}\mathrm{Cu} \\
(\mathrm{wt} \%)\end{array}$ & $\begin{array}{c}\mathrm{Zn} \\
(\mathrm{wt} \%)\end{array}$ & $\begin{array}{c}\mathrm{Pb} \\
(\mathrm{ppm})\end{array}$ & $\begin{array}{c}\mathrm{Ag} \\
(\mathrm{ppm})\end{array}$ & $\begin{array}{c}\mathrm{Au} \\
(\mathrm{ppb})\end{array}$ & $\mathrm{CaSO}_{4}$ & $\begin{array}{c}\mathrm{S} \\
\text { (sulfide) }\end{array}$ & $\begin{array}{c}\text { Volume } \\
(\mathrm{t})\end{array}$ \\
\hline 1 & 1.39 & 1.33 & 116 & 14.4 & 590 & 0.25 & 40.2 & 7 & 351,860 \\
2 & 1.80 & 0.63 & 83 & 8.0 & 890 & 0.19 & 44.9 & 1 & 904,780 \\
3 & 4.37 & 0.02 & 22 & 2.7 & 240 & 23.1 & 39.1 & 3 & 153,940 \\
4 & 4.90 & 0.55 & 98 & 41.1 & 790 & 8.66 & 44.6 & 5 & 954,260 \\
5 & 2.80 & 0.03 & 27 & 1.4 & 200 & 18.3 & 41.5 & 5 & 28,270 \\
6 & 2.80 & 0.03 & 27 & 1.4 & 200 & $(18.3)$ & $(41.5)$ & 5 & 301,590 \\
7 & 2.20 & 0.04 & 19 & 1.5 & 180 & 5.63 & 41.7 & 10 & 357,850 \\
8 & 1.25 & 0.01 & 19 & 0.7 & 80 & 9.39 & 34.8 & 3 & 319,190 \\
9 & 3.20 & 0.09 & 42 & 3.0 & 300 & 1.46 & 38.7 & 4 & 351,860 \\
10 & 1.92 & 0.02 & 15 & 0.8 & 70 & 0.49 & 42.9 & 2 & 161,990 \\
Weightted avgs. & 2.83 & 0.42 & 65 & 14 & 534 & 6.10 & 42.1 & & \\
\hline
\end{tabular}

Notes: Data are from Hannington et al. (Chap. 2, this volume); averages are based on N samples weighted according to the estimated bulk tonnage of each block. The locations of the different blocks are shown in Figure 8; volumes are calculated for cylindrical blocks rotated around the center of the deposit.

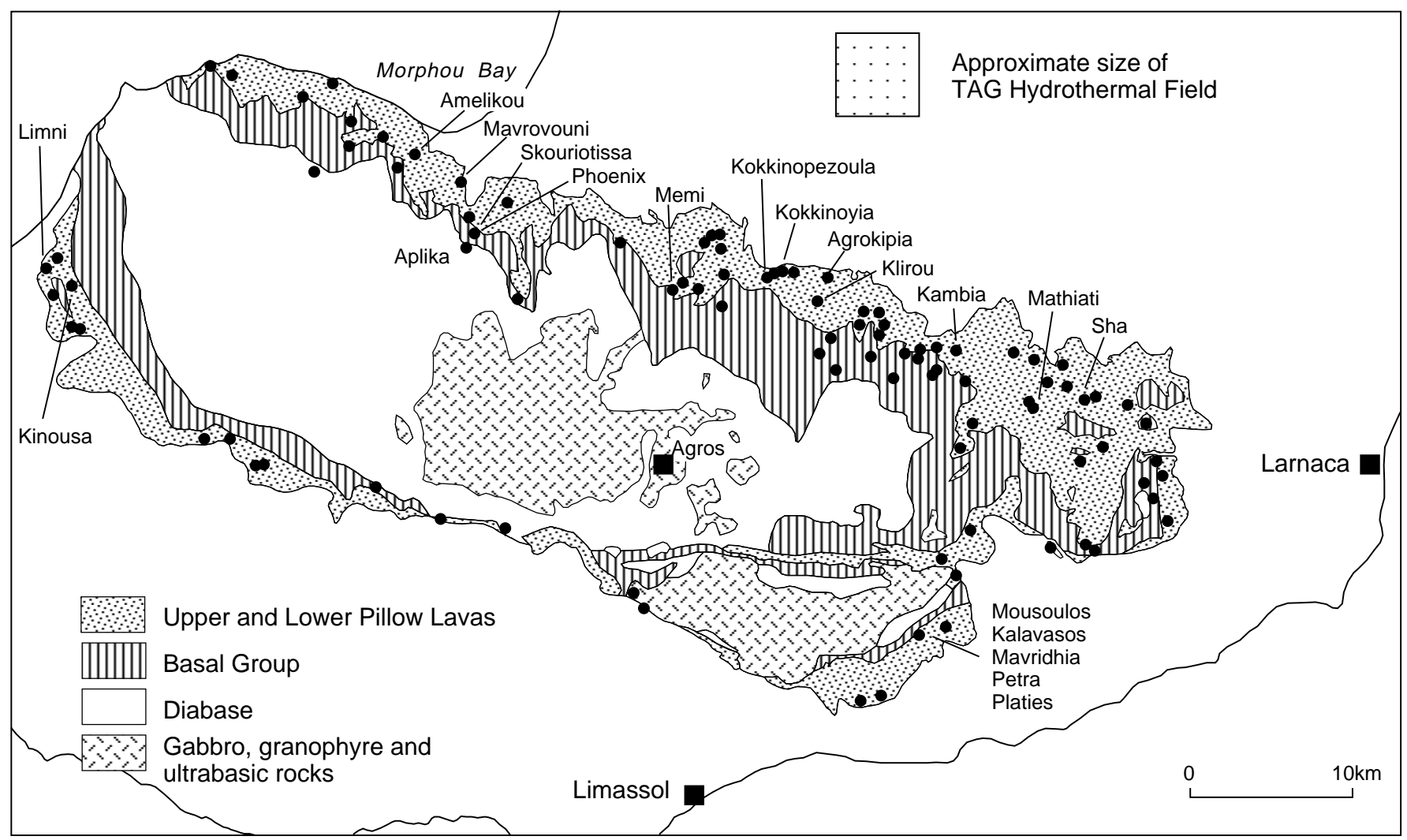

Figure 9. Location of sulfide deposits in the Troodos ophiolite complex of Cyprus. More than 90 sulfide occurrences are known in the Basal Group and in the Upper and Lower Pillow Lavas, surrounding the intrusive complex at the core of the ophiolite. The principal mining districts and large deposits are highlighted (after Bear, 1963; Constantinou, 1980). For comparison, the approximate size of the TAG hydrothermal field (5 km $\times 5 \mathrm{~km})$ is also shown. 
its consisted only of stockwork ore, with little or no massive sulfide developed (e.g., Limni, Pitharokhoma, Agrokipia B: Bear, 1963; Herzig, 1988; Richards et al., 1989). The high-grade stockwork zones are usually pipe-like bodies (i.e., much deeper than they are wide), resulting in a distinctive funnel-shaped cross section for the mineralized zones. Large, diffuse zones of quartz-pyrite veining and disseminated mineralization usually envelope the pipe-like stockwork. At Skouriotissa, the stockwork mineralized zone was also traceable up to $700 \mathrm{~m}$ into the footwall. Such stockwork zones can generally be shown to occupy synvolcanic faults, which accounts for their considerable vertical extent (e.g., Adamides, 1980).

Most of the Cyprus-type massive sulfides consist of a single, discrete lens, although some include vertically-stacked ore bodies (e.g., Aarja, in Oman: Gibson and Koski, 1995). The deposits are usually described as low-relief mounds, having a relatively flat hangingwall contact with the overlying sediments or pillow lavas. They commonly have a distinctive asymmetric shape which is attributed to their original depositional setting (i.e., deposition adjacent to a synvolcanic fault or graben wall, within small sub basins). Many of the deposits are also truncated by late movements along the faults and may have developed their present geometry late in their history. The massive sulfide lenses are often thickest along one flank and thin outward, away from the fault. Erosion or gradual flattening of the ore lenses on back-tilted, listric faults likely also occurred at the active margins of the grabens, and dissection and eventual degradation of the deposits by faulting may have been common, as in the Mir zone in TAG field. In contrast to the active TAG mound, many of the deposits in Cyprus have elongate shapes, reflecting the strong fault control on the hydrothermal upflow. The Mathiati deposit (about the same size as TAG) is a little more than $50 \mathrm{~m}$ wide but $250 \mathrm{~m}$ long (Lydon and Galley, 1986), and the main ore bodies at Skouriotissa may have had an original strike length of up to $1 \mathrm{~km}$ (Bear, 1963). The present mapping of the TAG hydrothermal field indicates that some areas of sulfide mineralization may have similar strike lengths (e.g., up to $600 \mathrm{~m}$ of semicontinuous sulfide outcrop in the Mir zone and Alvin zone: Rona et al., 1993a, 1993b).

\section{Ore Types}

Cyprus-type deposits are characterized by a vertical zonation of ore types, including massive pyrite breccias, pyrite-silica breccias, a quartz-pyrite stockwork, and quartz-chlorite zones similar to that observed at TAG. Constantinou (1972) and Constantinou and Govett (1972) identified four main ore types that were subdivided largely on the basis of sulfur content. These included an ocherous horizon and sandy pyrite units at the top of the massive sulfides, a zone of massive pyritic ores containing 30-40 wt\% S (Zone A), a pyrite-silica zone containing 20-30 wt $\% \mathrm{~S}$ and up to $20 \mathrm{wt} \% \mathrm{SiO}_{2}$ (Zone B), and the underlying quartz-pyrite stockwork (Zone C). The distribution of the different ore zones is well represented by the Mathiati deposit, which closely resembles the TAG mound-stockwork complex (e.g., Fig. 11).

The upper parts of the massive sulfide lenses consist mainly of "conglomeratic ore," which comprises clasts and larger blocks of massive pyrite, up to $1 \mathrm{~m}$ across, in a matrix of friable, sandy pyrite. Except for the absence of anhydrite, these ores are identical to the pyrite breccias in the uppermost drill core from the TAG mound. By analogy with TAG, the sandy pyrite may represent detrital material "weathered out" of massive anhydrite that is no longer preserved in the deposits. The conglomeratic ore usually covers the top of the massive sulfide lenses to a thickness of up to $5 \mathrm{~m}$. In some deposits, conglomeratic ore constitutes the bulk of the ore mined (e.g., Mathiati: Lydon, 1984b) and in others it may be not present (e.g., Agrokipia: Constantinou and Govett, 1973). The clasts of pyrite in the conglomeratic ore are angular to subangular and are frequently nodular or spheroidal in appearance. They vary greatly in size, and the coarsest breccia fragments resemble the large talus blocks that occur on the flanks of the TAG mound (e.g., Lydon 1984b). Finer-grained, sandy pyrite locally is the dominant ore type (e.g., Kalavasos: Constantinou, 1972). The sandy pyrite is often weakly consolidated and generally has a high porosity; at Kalavasos this ore type is about $40 \%$ less dense than the underlying massive pyrite.

The massive pyrite ores (Zone A) consist of fine- to coarsegrained, granoblastic pyrite, often with abundant vuggy cavities lined by idiomorphic pyrite and quartz (Searle, 1972; Constantinou, 1972; Adamides, 1980; Lydon, 1984b). A thick section of these hard, "compact ores" typically occurs immediately below the conglomeratic ore and sandy pyrite. The compact ore consists of coarse, granular pyrite breccias or blocky ore with abundant interstitial pyrite. These ores closely resemble the carapace of pyrite-cemented breccias at the top and margins of the TAG mound. The massive pyrite is locally cut by late veins of colloform-banded pyrite and is increasingly brecciated upward. The pyrite blocks are largest at the base of the massive sulfide lens, and the sandy pyrite matrix is gradually replaced by quartz and pyrite cement. In some cases, fossilized worm tubes have been recognized in the pyritic breccias (Haymon et al., 1984; Oudin et al., 1985; Lescuyer et al., 1988), and fragments of chimney structures are also observed (Oudin and Constantinou, 1984). However, progressive brecciation of the massive sulfides and continuous hydrothermal recrystallization means that these primary features are only rarely preserved in the massive sulfide lenses.

The massive sulfide lenses are typically underlain by a metersthick, basal zone of quartz-pyrite breccias, referred to as the pyritesilica zone (Zone B). Although this zone marks the top of the quartzpyrite stockwork, it is usually distinguished by the absence of obvious basalt fragments. Corroded fragments of pyrite in the breccias have a distinctive nodular appearance and typically are surrounded and partially replaced by quartz. The silica cement consists of variable amounts of quartz, chalcedony and red jasper, all of which are demonstrably later than the pyrite (Constantinou, 1972). The common presence of red jasper in the pyrite-silica ores suggests that this zone represents the top of the pillow sequence in which the basalt substrate has been completely replaced by quartz and pyrite. As in the footwall breccias at TAG, the intense silicification in the pyrite-silica zone has largely destroyed any primary igneous textures in the lavas. Stockwork or replacement ore (Zone C) occurs immediately below the pyrite-silica zone and comprises mainly quartz-pyrite veins with minor chalcopyrite in intensely altered and mineralized lavas. The stockwork mineralization consists of anastomosing networks of subvertical quartz-pyrite veinlets and veins up to $12 \mathrm{~cm}$ in width, in a predominantly quartz-chlorite matrix. Most veins exhibit crustiform banding that records multiple crack-seal events, similar to that observed at TAG. The veining increases in intensity, immediately below the massive sulfides, so that the underlying pillow lavas appear brecciated in situ (basal "pseudobreccias"). The sulfide veins become wider and more numerous towards the top of the stockwork zone and locally coalesce, leaving behind relict clasts of altered basalt in the core of the massive sulfides. Small lenses of massive sulfide are also commonly found in the lower part of the stockwork zones (e.g., Agrokipia B), possibly representing lateral replacement within permeable zones such as interflow breccias, hyaloclastite, or sediments. Chalcopyrite veining occurs mainly in the lower, quartz-rich part of the stockwork zones. At Limni, chalcopyrite veins up to $15 \mathrm{~cm}$ in thickness were observed (Hutchinson and Searle, 1970; Searle, 1972), but these are exceptional.

\section{Mineralogy}

The mineralogy of cupriferous pyrite deposits in Cyprus is simple. Pyrite accounts for $>90 \%$ of the sulfides in nearly all cases. Con- 
A

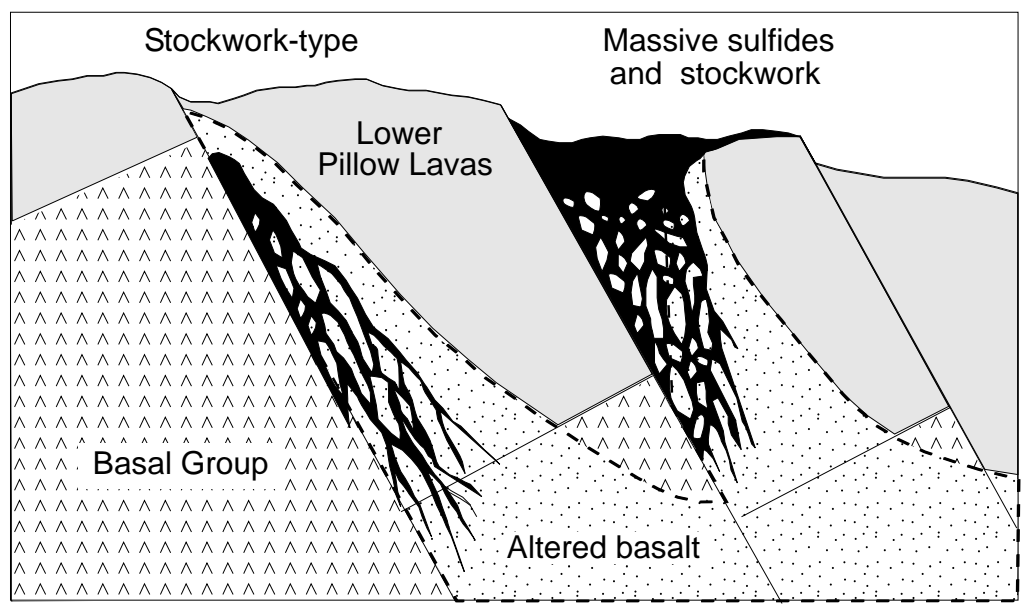

B

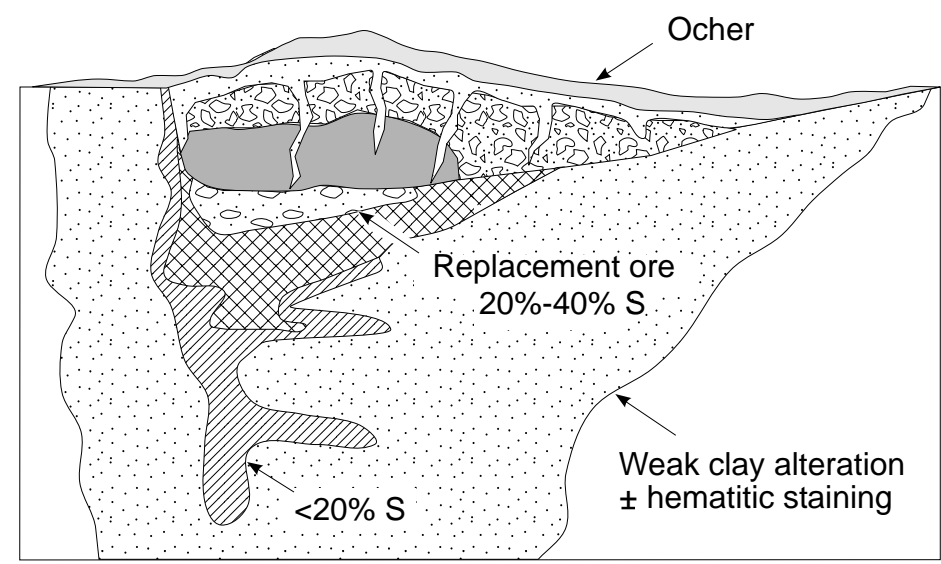

Zone A (>40\% S)

Sandy ore

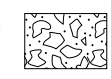

\section{Conglomeratic ore Pyrite breccia}

Zone C $(<20 \%$ S $)$

\section{Zone B $(20-40 \%$ S $)$}

Silica-sulfide ores Pyrite-silica breccia
Quartz-pyrite stockwork
Compact ore Massive pyrite
Figure 10. Generalized cross sections through typical Cyprus-type massive sulfide deposits showing the distribution of ore different ore types and styles of mineralization. A. Typical settings of stockwork-type and massive sulfide ores in Cyprus, showing fault control of hydrothermal upflow and associated alteration. B. Composite schematic section showing vertical distribution of ore types in Cyprus massive sulfides. C. Summary of textural and mineralogical characteristics of different ore zones in Cyprus-type massive sulfides. (Sources: Searle, 1972; Constantinou, 1972; Adamides, 1980).

\begin{tabular}{|c|c|c|c|c|}
\hline \multicolumn{2}{|c|}{ Lithology } & Description & Mineralogy & $\% \mathrm{Cu}$ \\
\hline 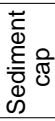 & & $\begin{array}{l}\text { Fe-rich and siliceous pelagic mudstones, } \\
\text { hydrothermal sediments and oxidized } \\
\text { massive sulfides with graded sandy pyrite } \\
\text { beds and fragments of colloform pyrite }\end{array}$ & $\begin{array}{l}\text { Silica, hematite, magnetite, } \\
\text { goethite, jarosite, +carbonate, } \\
\text { pyrite, sphalerite, chalcopyrite, } \\
\text { covellite, marcasite, native Au }\end{array}$ & $0.5-1.5$ \\
\hline \multirow{2}{*}{ 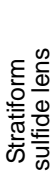 } & & $\begin{array}{l}\text { Black sandy pyrite grading down into } \\
\text { sulfide breccia ore with blocks of } \\
\text { colloform pyrite in a sandy matrix }\end{array}$ & $\begin{array}{l}\text { Pyrite, marcasite, sphalerite, } \\
\text { chalcopyrite, bornite, covellite, } \\
\text { pyrrhotite, galena, tennantite }\end{array}$ & $1.0-4.0$ \\
\hline & & $\begin{array}{l}\text { Massive fine-grained sulfide with granular } \\
\text { to idiomorphic texture and containing } \\
\text { open-space vugs. Cut by colloform to } \\
\text { sandy veins. }\end{array}$ & $\begin{array}{l}\text { Pyrite, chalcopyrite, sphalerite, } \\
\text { covellite, carollite, magnetite }\end{array}$ & $0.5-1.5$ \\
\hline \multirow{3}{*}{ 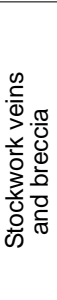 } & & $\begin{array}{l}\text { Basal siliceous breccia with sulfide, jasper } \\
\text { and volcanic fragments in a quartz- } \\
\text { rich matrix. }\end{array}$ & $\begin{array}{l}\text { Pyrite, marcasite, chalcopyrite, } \\
\text { sphalerite, pyrrhotite, quartz, } \\
\text { jasper, chalcedony }\end{array}$ & $0.4-1.2$ \\
\hline & & $\begin{array}{l}\text { Intense stockwork vein system with insitu } \\
\text { brecciation and silicification of basalt } \\
\text { flows. Massive to colloform veins with } \\
\text { jasper and basalt fragments. }\end{array}$ & $\begin{array}{l}\text { Pyrite, chalcopyrite, sphalerite, } \\
\text { quartz, illite, jasper, chlorite }\end{array}$ & $0.4-1.2$ \\
\hline & & $\begin{array}{l}\text { Discrete stockwork vein system with } \\
\text { multiple Fe oxide and sulfide vein } \\
\text { generations. Broader halo of jasper } \\
\text { infilled intrapillow spaces. }\end{array}$ & $\begin{array}{l}\text { Pyrite, chalcopyrite, sphalerite, } \\
\text { rutile, quartz, chlorite, illite, } \\
\text { jasper }\end{array}$ & $0.2-0.5$ \\
\hline
\end{tabular}




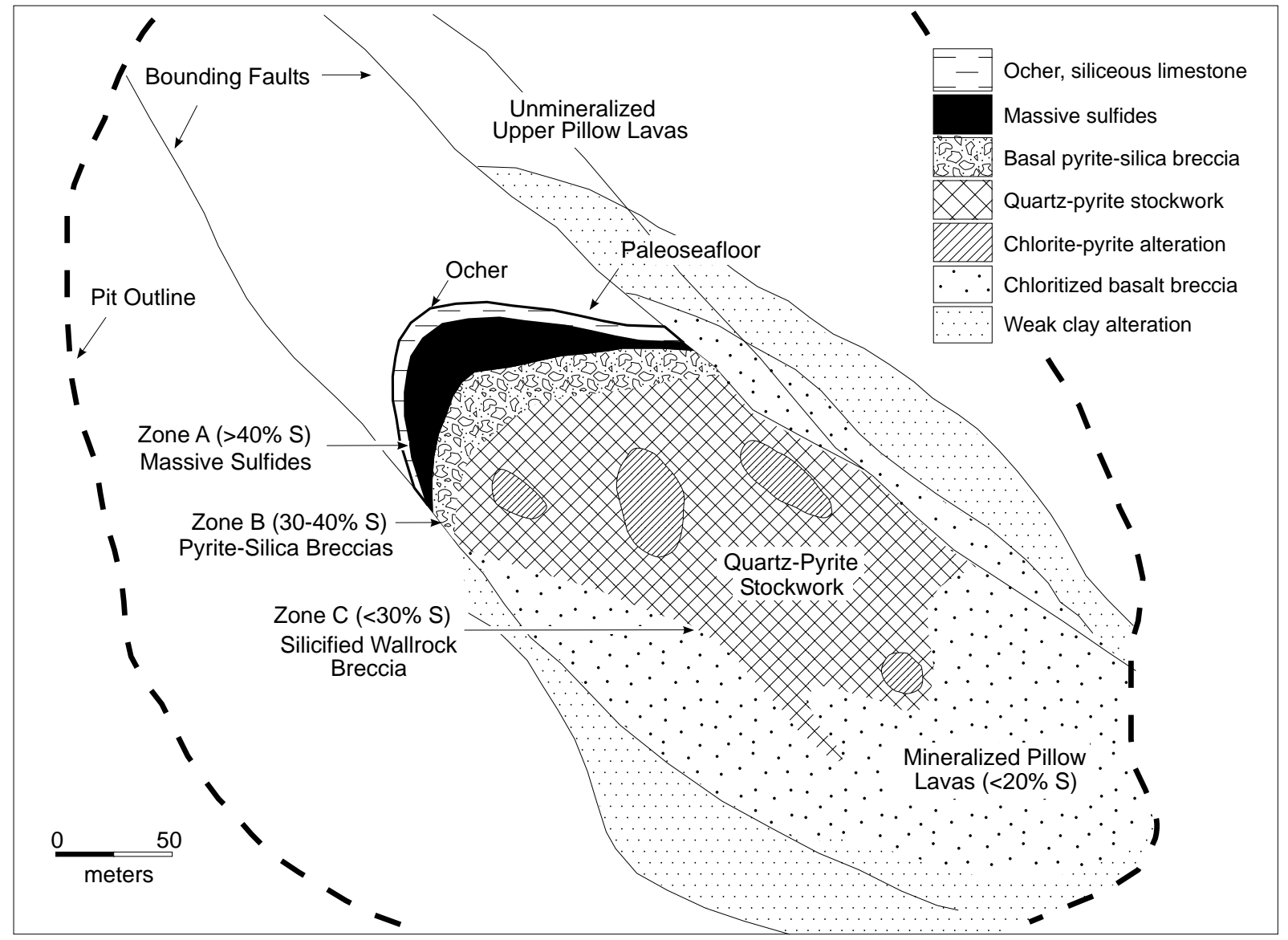

Figure 11. Example of the distribution of ore types and alteration in the North Mathiatis orebody (composite sketch of the open pit and $330 \mathrm{~m}$ level from Constantinou, 1980; Hadjistavrinou and Constantinou, 1980; Lydon and Galley, 1986). The host rocks are tilted $35^{\circ}$, exposing a section of the ore lens and underlying stockwork zone. The distribution of ore types, size of the underlying stockwork, and nature of mineralization are nearly identical to the TAG moundstockwork complex. Two parallel normal faults strongly control the distribution of mineralization and alteration.

stantinou (1972) recognized several types of pyrite in the deposits that closely parallel the textural varieties observed in the TAG mound. Pyrite I consists of massive, coarse-grained, euhedral pyrite and accounts for most of the massive ores. Pyrite II comprises mainly semi-consolidated, granular aggregates of pyrite, usually in a sandy pyrite matrix. Pyrite III is colloform massive pyrite that mainly cements the earlier breccia ores. A consistent paragenesis among the different types of pyrite was recognized, in which the compact ores are products of the early brecciation of massive pyrite and later cementation by colloform pyrite. The compact ores are commonly extensively recrystallized, and the coarsest grained, pyrite, locally occurs as large, poikilitic euhedra up to a centimeter across. This pyrite is overgrown by multiple generations of later euhedral pyrite and commonly contains minor interstitial chalcopyrite. Chalcopyrite locally fills open spaces in the conglomeratic ores, but is most abundant in quartz-pyrite veins that crosscut the earlier pyrite breccias.

Although sphalerite is rare in the Cyprus deposits, some exhibit local concentrations of sphalerite at the tops of the massive sulfide lenses. Where it occurs, the sphalerite generally coincides with local enrichments in chalcopyrite, filling open spaces among the uppermost pyrite breccias (Constantinou, 1972; Constantinou and Govett, 1973). This sphalerite was likely deposited from late-stage, hydrothermal fluids or was remobilized from the underlying massive sulfides during successive hydrothermal events. Low-Fe sphalerite is rare in most of the Cyprus deposits (Fig. 5), although the data may reflect a strong sampling bias toward the massive pyritic ores. At
Mathiati, late-stage, Fe-poor sphalerite is present in some open cavities, together with chalcedonic silica. Similar, low-Fe sphalerite is present in the upper parts of the deposits in Oman (e.g., Ixer et al., 1986). Pseudomorphs of sphalerite after wurtzite have been recognized in massive pyritic ores from both the Cyprus and Oman deposits (Ixer et al., 1984).

As in the TAG mound, pyrrhotite is absent in most Cyprus-type deposits, although minor inclusions of pyrrhotite in pyrite and pseudomorphs of pyrite after pyrrhotite have been noted in some cases (Constantinou, 1972; Ixer et al., 1984, 1986). Individual deposits possess trace amounts of other minerals, such as marcasite, cubanite, bornite, idaite, bravoite, carollite, and mackinawite. Ghost-textures of metastable phases such as isocubanite also have been reported (Oudin and Constantinou, 1984; Ixer et al., 1984). Sphalerite-rich ores at the tops of some deposits contained minor inclusions of galena, but these were rare (e.g., Agrokipia B, Mousoulos, Mathiati, and Kokkinoyia: Constantinou and Govett, 1972; Constantinou, 1980; Searle, 1972)

\section{Bulk Composition and Metal Zoning}

The bulk compositions of the Cyprus deposits are strikingly similar to that of the TAG mound (Tables 1 and 2). Concentrations of $\mathrm{Cu}$ in the massive sulfides range from 0.2 to $7.7 \mathrm{wt} \%$, and average close to $2 \mathrm{wt} \%$, whereas $\mathrm{Zn}$ concentrations are generally less than $0.1 \mathrm{wt} \%$. Where analyzed, the sulfides are notably poor in $\mathrm{Pb}(<0.01$ to 0.04 
wt $\%$ ). The base metal contents of these deposits are generally low, owing to the dilution by large volumes of pyrite. Drilling intersections through the Mousoulos and Kokkinoyia deposits exhibit strong vertical metal zonation, similar to that at TAG (Fig. 12). $\mathrm{Cu}$ and $\mathrm{Zn}$ are both concentrated in the uppermost part of the massive sulfide lenses, although Constantinou and Govett (1972) pointed out that the $\mathrm{Cu}$ grades are erratic and usually do not form a continuous zone across the top of the deposits (e.g., Kalavasos and Limni: Searle, 1972). The pyritic sulfides generally have low trace-element contents, although they locally show zoning in $\mathrm{Co}$, Se, Mo, and As. Cobaltian pyrite is present in some deposits, and Co is normally enriched in pyrite and chalcopyrite within the stockwork zone (Fig. 12). Bulk cobalt concentrations locally reach $3500 \mathrm{ppm}$, but are typically $<100$ ppm (Constantinou, 1980). Similar co-enrichments in Co, Ni, and Mo are also evident in the sulfides at TAG. Although discrete Co-minerals were not identified, a recently documented occurrence of Co-pentlandite in another sulfide deposit on the Mid-Atlantic Ridge (Mozgova et al., 1996) suggests that similar minerals may be present in trace amounts at TAG.

Precious metal concentrations in the Cyprus deposits range from $0.1 \mathrm{ppm}$ Au to $2 \mathrm{ppm} \mathrm{Au}$ and $<5 \mathrm{ppm} \mathrm{Ag} \mathrm{up} \mathrm{to} 70 \mathrm{ppm} \mathrm{Ag}$. Several deposits yielded more than 1,000 kg Au (e.g., Kalavasos, Mavrovouni: Bear, 1963; Herzig et al., 1991). The historical production of gold from these deposits (mainly from oxidized zones at surface) has led to the common impression that a strong $\mathrm{Cu}-\mathrm{Au}$ association is characteristic of ophiolite-hosted massive sulfides (e.g., Hutchinson, 1965, 1973). However, studies of the gold distribution at TAG indicate a strong $\mathrm{Zn}-\mathrm{Au}$ association in the uppermost sulfides (Hannington et al., 1995b). This may indicate that important concentrations of gold in the Cyprus deposits were overlooked in the $\mathrm{Zn}$-rich ores that were left unmined. A number of Zn-rich massive sulfides with high gold contents are known in the ophiolites of Newfoundland (e.g., Betts Cove and Tilt Cove: Hurley and Crocket, 1985; Tuach et al., 1988; Santaguida and Hannington, 1995) as well as in the Josephine ophiolite (Turner Albright: Kuhns and Baitis, 1987). In general, the very low Ag/Au ratios at TAG and Cyprus are characteristic of cupriferous pyrite deposits and reflect a combination of the source rock composition (low $\mathrm{Ag} / \mathrm{Au}$ ratios in MORB) and the effects of hydrothermal reworking (e.g., Hannington et al., 1995b).

\section{Sulfur Isotopes}

Sulfur isotope compositions of the TAG sulfides and representative samples from the deposits in Cyprus are compared in Table 6. The average $\delta^{34} \mathrm{~S}$ values for both TAG and the Cyprus sulfides are higher than that in many high-temperature black smoker chimneys (e.g., $\leq 2 \%$ at $21^{\circ} \mathrm{N}$ : Zierenberg et al., 1984; Woodruff and Shanks, 1988) and more closely resemble that of the large massive pyrite deposits at Galapagos (e.g., 5\%o-6\%o; Skirrow and Coleman, 1982). The heavy $\delta^{34} \mathrm{~S}$ signature most likely reflects the long-term evolution of the mound in comparison to smaller, high-temperature Black Smoker Complexes. Numerous authors have demonstrated that reduction of seawater sulfate during high-temperature mixing is the principal cause of increasing $\delta^{34} \mathrm{~S}$ values in seafloor hydrothermal systems (Shanks and Seyfried, 1987; Woodruff and Shanks, 1988). However, at TAG, incremental reaction of high-temperature, endmember fluids with pre-existing anhydrite in the mound is a more likely near-surface process that could result in large positive shifts in $\delta^{34} \mathrm{~S}$ of the deposited sulfides (e.g., Janecky and Shanks, 1988; Shanks et al., 1995). Heavy $\delta^{34} S$ compositions of the Cyprus massive sulfides imply that similar processes operated in these deposits, although anhydrite is no longer present in the ores. Detailed discussion of isotopic variations in the TAG mound are presented elsewhere in this volume.

\section{Deposits of the Semail Ophiolite, Oman}

More than 150 massive sulfide prospects have been discovered along the 500-km strike length of the Semail ophiolite in northern Oman (Coleman et al., 1979; Lescuyer et al., 1988). Most are clustered in groups about $25-50 \mathrm{~km}$ apart (Fig. 13). Of 25 major prospects, 3 have been mined (Bayda, Lasail, Aarja: Table 1). As in Cyprus, the producing mines ranged in size from 1 to 8 million $t$, but with many smaller sulfide occurrences in each camp. The Geotimes Unit, a sequence of basaltic pillow lavas up to $1.5 \mathrm{~km}$ thick, hosts the main massive sulfide deposits, as well as abundant $\mathrm{Fe}$ - and Mn-rich sediments (Fleet and Robertson, 1980). The morphology, ore types, mineralogy, and geochemistry of the deposits have many similarities to the cupriferous pyrite deposits of Cyprus (e.g., Ixer et al., 1984; Lescuyer et al., 1988; Batchelor, 1992). However, several of the deposits (e.g., Rakah, Al Aajal) exhibit mineralogical and geochemical characteristics more similar to massive sulfides currently forming in immature back-arc rifts (e.g., Herzig and Hannington, 1995).

As in Cyprus deposits, the deposits of the Semail ophiolite occupy distinct graben-like structures and exhibit a strong structural control on mineralization, subparallel to the regional sheeted dike swarm (i.e., the spreading axis). At Bayda, the massive sulfides appear to be confined to a narrow 70-m-wide graben or fissure. The basal breccia beneath the deposit is a mixture of sulfide and volcanic fragments in a quartz-rich matrix and is interpreted to be altered and mineralized talus from the nearby graben wall (Koski et al., 1990). The large Lasail deposit ( 8 million $\mathrm{t}$ ) is also an elongate body with a length of 500 $\mathrm{m}$, a width of $300 \mathrm{~m}$, and a thickness of $60 \mathrm{~m}$ (Collinson, 1986). Although the thickest part of the deposit is distinctly mound-shaped, the sulfides thin out along the margins into Fe- and Si-rich hydrothermal sediments (Koski and Haymon, 1988). At Lasail and Aarja, the classic "conglomeratic ores," typical of Cyprus-type deposits, are poorly developed or absent, and the massive sulfides exhibit strong layering and banding throughout the main lenses (R. Koski, unpubl. data; Ixer et al., 1984, 1986). At Al Aajal, the mineralization consists of sulfidehematite layers deposited on top of chloritized basalts. This may reflect deposition of sulfides within a brine pool or by subseafloor replacement, rather than as a mound-stockwork complex (Lescuyer et al., 1988). Gossans are well developed in the deposits of Oman, but many have formed since their uplift and exposure.

The deposits in Oman are also characterized by highly variable bulk compositions, and locally possess distinctive polymetallic ores (e.g., Tables 1, 2). The deposits at Bayda and Lasail have high $\mathrm{Cu}$, $\mathrm{Co}, \mathrm{Se}, \mathrm{Ni}$, and Mo, similar to the massive sulfides of Cyprus and in the TAG mound (Ixer et al., 1986). At Bayda, the chalcopyrite locally contains traces of molybdenite and carrollite (Ixer et al., 1984). In contrast, the ores at Aarja contain high $\mathrm{Zn}, \mathrm{Pb}, \mathrm{Ag}$, and $\mathrm{Au}$ (Coleman et al., 1979; Ixer et al., 1984). This deposit more closely resembles the Zn-rich massive sulfides found at Turner Albright in the Josephine ophiolite (Kuhns and Baitis, 1987; Zierenberg et al., 1988). At Rakah and Hayl-as-Safil, the massive sulfide lenses contain siliceous, sinter-like zones and the ores locally include abundant arsenopyrite, tennantite, and enargite (Lescuyer et al., 1988). The differences between these $\mathrm{Zn}$-rich deposits and the cupriferous pyrite deposits of Cyprus may reflect only a lower temperature of formation, but the sulfides at Rakah and Hayl-as-Safil have metallogenic signatures that suggest a possible closer relationship to subduction-related processes (e.g., Calvez and Lescuyer, 1991).

\section{DEVELOPMENT OF THE MOUND-STOCKWORK COMPLEX IN CYPRUS-TYPE DEPOSITS}

Numerous models for the development of Cyprus-type, moundstockwork complexes have been proposed based on observations 
Mousoulos Orebody (Hole 168)

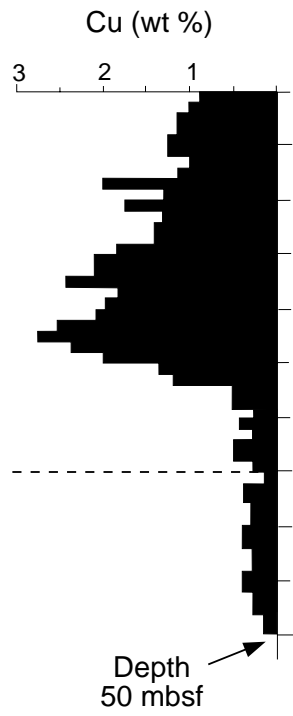

$\mathrm{Zn}(\mathrm{wt} \%)$

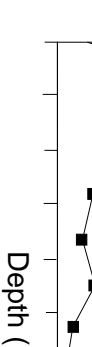

123
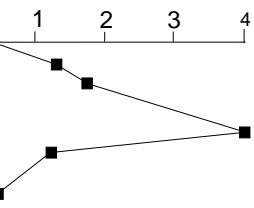

$=2$

Mousoulos Orebody (Hole 168)

Co (ppm)

$\mathrm{Ni}(\mathrm{ppm})$

$4=-160$

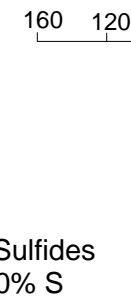

$30 \%-40 \%$ S
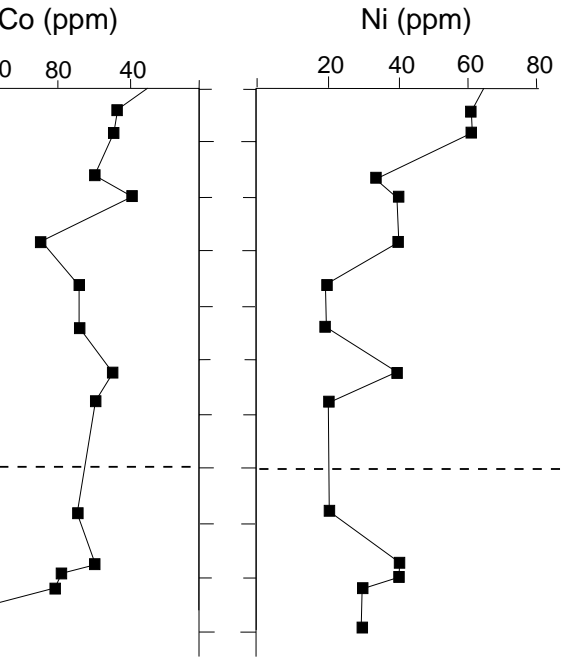

Stockwork

$20 \%-30 \%$ S

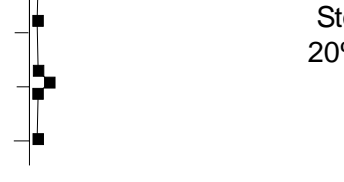

曰

Kokkinoyia Orebody (Hole M49)
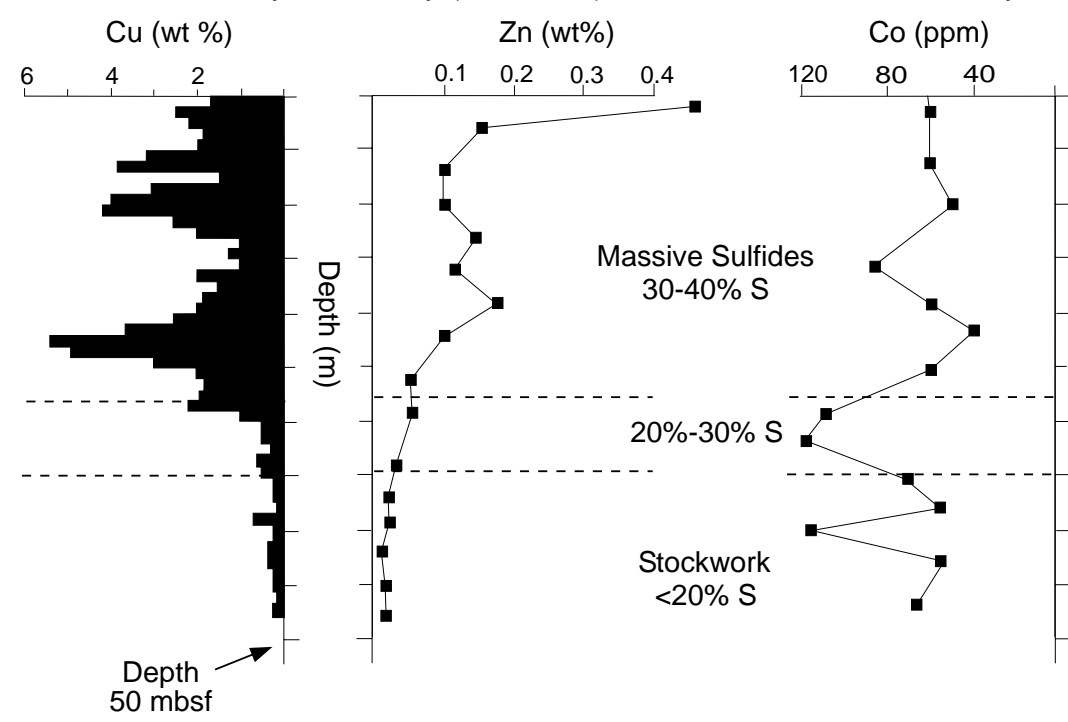

Kokkinoyia Orebody (Hole M49)

$\mathrm{Ni}(\mathrm{ppm})$

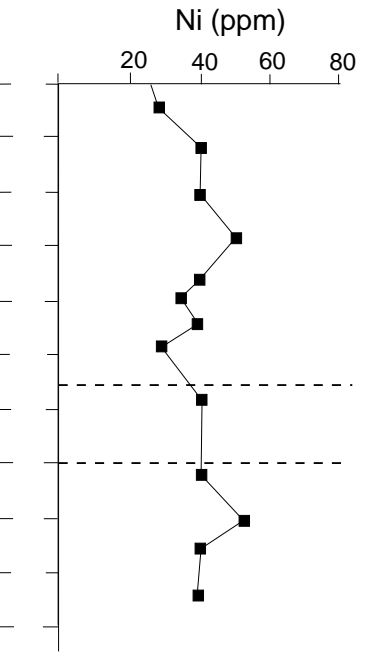

Figure 12. Drill section of the Mousoulos and Kokkinoyia deposits, Cyprus, showing the distribution of $\mathrm{Cu}, \mathrm{Zn}, \mathrm{Co}$, and Ni through the massive sulfide lenses and underlying stockwork zones. Data are from Constantinou (1972).

from active seafloor vents and preserved deposits in the geologic record (e.g., Lydon, 1984a, 1984b; Hekinian and Fouquet, 1985; Hannington et al., 1995a). Mound-like sulfide deposits are constructed from a combination of accumulating sulfide talus at the seafloor and by mineralization beneath the seafloor during phases of hightemperature upflow. The abundant sulfide debris is derived mainly from the collapse of large sulfide chimneys and by degradation of the growing mound along active fault scarps. Drilling of the TAG mound indicates that the interiors of many of the deposits are likely composed of a complex assemblage of sulfide breccias that have accumulated during various stages of deposit growth. As the talus is incorporated in the mound it becomes cemented by the precipitation of other sulfides and may be extensively reworked by later hydrothermal fluids. However, to a large extent, the extensive brecciation of the sulfides at TAG is caused by processes that are internal to the mound- stockwork complex, rather than by erosion and mass-wasting at the surface. Anhydrite precipitation and dissolution is considered to be of fundamental importance in the development of the breccia ores at TAG, and this observation suggests important modifications to current models for the genesis of similar ore types in Cyprus-type massive sulfides. An empirical model for the growth of the TAG mound based on drilling during Leg 158 is illustrated in Figure 14.

\section{Growth of Hydrothermal Mounds}

The internal structure of the TAG mound consists of an outer carapace of variably silicified and framework-supported pyrite breccias that overlie a central core of dominantly anhydrite-supported breccias within the high-temperature upflow zone. The anhydrite zone sits above a vertically extensive quartz-pyrite stockwork. The high- 
Table 6. Comparison of $\delta^{34} \mathrm{~S}$ values from TAG and Cyprus.

\begin{tabular}{lllc}
\hline Sample & \multicolumn{1}{c}{ Deposit } & \multicolumn{1}{c}{$\delta^{34} \mathrm{~S}$} & Source \\
\hline MH-1 & Sha & +1.9 & 1 \\
MH-3, 4 & Memi & +3.9 to +5.4 & 1 \\
MH-7 & Kinousa & +7.7 & 1 \\
MH-10 & Agrokipia A & +3.7 & 1 \\
MH-11 & Agrokipia B & +5.6 & 1 \\
MH-13 & Uncle Charles & +8.2 & 1 \\
MH-20 & Mathiati & +3.8 to +5.5 & 1,2 \\
& TAG & +4.4 to +8.2 & 3 \\
\hline
\end{tabular}

Note: Sources: 1 = this study; $2=$ Lydon $(1984 a, 1984 b) ; 3=$ Herzig et al. (Chap. 4 , this volume).

temperature hydrothermal fluids reach the seafloor through a network of quartz-pyrite-anhydrite veins that crosscut the pyrite-anhydrite breccias. The abundant anhydrite within the upflow zone is deposited by the progressive heating of seawater that is drawn into the mound beneath the central Black Smoker Complex. During periods of high-temperature upflow, infilling of the pyrite breccias with anhydrite effectively "inflates" the mound, and the breccias remain supported as long as high-temperature upflow is maintained. However, because the high-temperature upflow is episodic over the life of the deposit, the breccias in the central portion of the mound periodically collapse as a result of the dissolution of the anhydrite cement. During periods of inactivity, the penetration of cold seawater into the deposit promotes the dissolution rather than precipitation of anhydrite, owing to the declining temperatures in the core of the mound. The complex assemblage of breccia ores that composes the bulk of the deposit reflects the repeated fragmentation, cementation, and hydrothermal recrystallization of the earlier sulfides. Pyrite breccias that are now at the base of the mound were originally formed near the seafloor during an earlier stage in the growth of the deposit and have since been overgrown and extensively recrystallized by later hydrothermal events. The apparent stratigraphy within the mound, from framework-supported breccias, through pyrite-anhydrite breccias, to quartz-cemented breccias, reflects the progressive infilling and replacement of the breccias, first by anhydrite and then by quartz. Large collapse features at the surface of the mound may be manifestations of anhydrite dissolution as the high-temperature upflow zone migrated across the deposit or periodically ceased to exist altogether.

Renewed episodes of high-temperature upflow are apparently focused through the collapsed breccias, resulting in the repeated overgrowth and cementation of the fragmental sulfides. The cherty carapace is periodically breached during the collapse of the underlying anhydrite-rich breccias, allowing fresh seawater to be drawn into the mound during renewed periods of high-temperature upflow. An anomalous zone of low heat flow measured over the western part of the mound has been interpreted to reflect local recharge below the presently active central Black Smoker Complex (Becker and Von Herzen, 1996). Seawater also apparently penetrates the upflow zone through the permeable footwall basalt. This is indicated by the presence of anhydrite veins at considerable depths within the silicified stockwork zone (down to $50 \mathrm{mbsf}$ ). At these depths, it seems likely that seawater can penetrate the subseafloor only by renewed cracking induced by on-going tectonic activity. This is supported by the extensive crack-seal veining that is readily apparent in the core recovered from the stockwork zone. The cherty carapace at the top of the mound also helps to focus the high-temperature discharge. The silicification is a likely consequence of the hydrothermal fluids cooling in the uppermost part of the mound; the cherty silica migrates upward with the growth of the deposit so that the deposit is nearly always capped by a silicified zone. The distinctive terraces on the mound may reflect the accumulation of sulfides above these intact portions of an earlier mound complex.

\section{Development of Subseafloor Stockworks}

Much of the altered substrate at TAG has been replaced by quartz and pyrite, and the most intense silicification and replacement extends 10 to $20 \mathrm{~m}$ below the adjacent seafloor (e.g., Fig. 3). Although intact basalt clasts are most abundant below $40 \mathrm{mbsf}$, the first clasts were encountered at a depth of only 22 mbsf (i.e., within the mound). Vertical displacements of the stockwork (e.g., by a series of small step faults) could account for the presence of these less-altered basalt fragments higher up in the mound; however, the abundance of wallrock fragments in the pyrite-silica zone implies that much of the mineralization was emplaced within a pillow mound or talus pile of in situ pillow breccia.

As in Cyprus, the underlying quartz-rich stockwork consists of two main parts: an upper zone of quartz-cemented, pyrite-silica breccias, and a lower zone of intense fracturing and quartz-pyrite veining. A complex history of quartz deposition is preserved, and multiple generations of open-space filling and crustiform-banded quartz is clearly visible at the hand-specimen scale and in thin section. Early, chalcedonic quartz is typically overprinted and partially replaced by later, coarse-grained, euhedral quartz at much higher temperatures (Petersen et al., this volume). Progressive development of the upflow zone beneath the deposit involves mainly the replacement of basalt talus and the penetration of the quartz-pyrite stockwork downwards into the underlying pillow breccias. Crackle-brecciation and apparent hydrofracturing is common at the centimeter scale, with many veins containing fragments of altered wallrock (possible evidence of local fluid over-pressuring within the stockwork). The large volume increase associated with quartz veining in the lower part of the stockwork is partly accommodated by the wholesale dissolution of basalt breccias. However, adequate fracture permeability within the silicified stockwork must have been maintained during each high-temperature pulse to ensure that the upflow zone did not become choked with anhydrite. This may indicate that the high-temperature venting is focused by fissures undergoing active extension or simply that seawater cannot entirely penetrate the highest-temperature portion of the upflow zone (i.e., the entrained seawater is heated and stripped of its sulfate prior to reaching the highest-temperature conduits).

The development of the present anhydrite zone at the top of the quartz-pyrite stockwork appears to postdate silicification. Anhydrite veining associated with the current phase of high-temperature upflow crosscuts the quartz-pyrite stockwork and is related to only the most recent hydrothermal event. In contrast, the silicification of the breccia ores at the base of the mound is cumulative and has progressed through many successive hydrothermal pulses. The quartz moves up through the mound-stockwork complex with time and eventually displaces the anhydrite matrix in the overlying breccias.

Although the stockwork zone at TAG was not comprehensively drilled, the available profiles indicate that it is comparable in size and shape to the most intensely mineralized zones beneath the Cyprus deposits. In the Cyprus deposits, the depth to the bottom of the quartzsulfide stockwork is usually at least twice the width of the seafloor mound. As in the TAG deposit, the quartz veins are texturally complex and preserve a record of multiple episodes of brecciation and high-temperature upflow. Banded chalcedonic quartz is most abundant in the upper part of the stockwork, whereas coarse-grained, euhedral quartz is most common at depth. Overprinting of the lowertemperature, chalcedony by later euhedral quartz is usually evident (Constantinou, 1972; Constantinou, 1980).

The remnants of pyritic, interpillow cherts are common in the stockwork zones of Cyprus-type massive sulfides and are evidence that high-temperature fluids occupied the same upflow zones as earlier lower-temperature vents. At Mathiati, chert fragments in the quartz-pyrite stockwork are still recognizable, and jasper veins up to several centimeters wide are cut by later quartz-pyrite-chlorite veins 


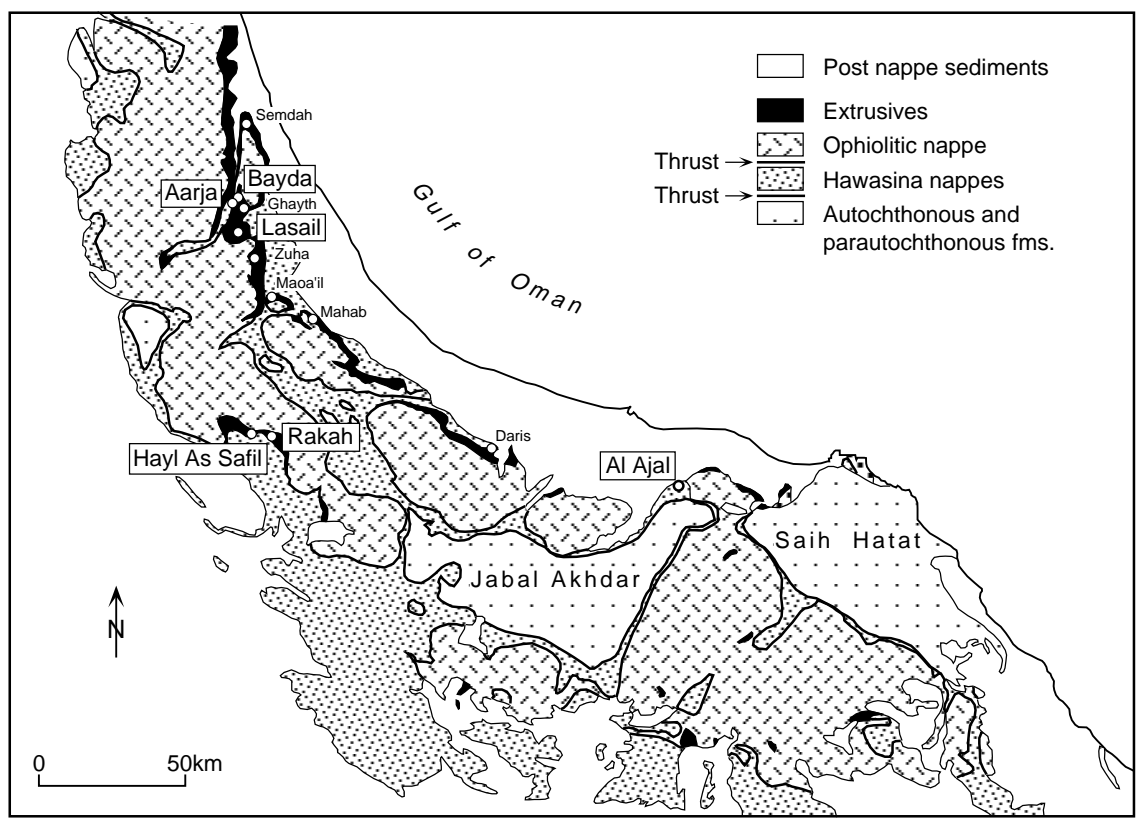

Figure 13. Location of sulfide deposits in the Semail ophiolite of the northern Oman Mountains (after Calvez and Lescuyer, 1991).
(Lydon, 1984b; Lydon and Galley, 1986). At Lasail and Bayda, the early stockwork also contained abundant quartz-jasper veins, as well as magnetite-quartz and quartz-hematite (Collinson, 1986). The veins fill interpillow spaces in the basalt below the deposits and appear to have been feeder zones for low-temperature chert deposits forming at the seafloor. This early silicification may have contributed to the sealing of the uppermost pillow lavas and thereby promoted the focusing of high-temperature upflow and the development of the quartz-pyrite stockwork.

\section{Distribution of Alteration}

Alteration associated with the TAG mound-stockwork complex is confined to a discrete pipe-like zone beneath the massive sulfide lens. The main alteration minerals are quartz, chlorite, illite, and kaolinite. Pyrite, which occurs as a replacement of Fe-bearing igneous phases, is commonly associated with the intense clay alteration in the central portion of the stockwork. Chloritized pillow-rim breccias occur locally closer to the seafloor. Beyond the chloritized halo of the stockwork, the basalts are locally hematized. Much of the chlorite alteration adjacent to the stockwork zone is likely a consequence of the entrainment of seawater into the hydrothermal upflow rather than the direct interaction of high-temperature fluids with fresh basalt (cf. Embley et al., 1988; Janecky and Shanks, 1988). An apparent highpermeability zone at the base of the quartz-rich stockwork is also indicated by the loss of drilling fluids at about 80-90 mbsf (Humphris, Herzig, Miller, et al., 1996). This zone contains an abundance of buffcolored basalt fragments and may indicate the presence of an aquifer zone in interflow breccias or hyaloclastite. Details of the alteration mineralogy and chemistry of the basalts are presented elsewhere in this volume.

A magnetic low coincident with the TAG alteration pipe is interpreted to be the product of crustal demagnetization associated with hydrothermal upflow immediately beneath the deposit (Tivey et al., 1993). These effects are superimposed on a broader zone of demagnetization encompassing the whole TAG field (i.e., a large sea-surface magnetic anomaly over an area of $2 \mathrm{~km} \times 8 \mathrm{~km}$ : Wooldridge et al., 1992). Because the magnetic character of the rocks is permanently changed by hydrothermal alteration on a large scale, these effects are commonly preserved in the rock record, and similar magnetic anomalies have been documented in altered rocks from the Agrokipia B deposit (e.g., Johnson et al., 1982; Johnson and Pariso, 1987). The geometry of crustal demagnetization (a narrow, focused zone at the seafloor and broader zones at depth) is consistent with that of discrete alteration pipes superimposed on pervasive alteration at depth below the deposits (e.g., Schiffman et al., 1987).

The distribution of alteration in typical Cyprus-type deposits is illustrated by the North Mathiati pipe (Fig. 11). The different alteration zones at Mathiati are similar to those of other Cyprus deposits, although the mineralogy and chemistry of the alteration may vary in detail between the deposits (e.g., Richards et al., 1989). At the margins of the deposit, the contact between the ore zone and the country rocks is abrupt, often with only weak alteration of the basalts adjacent to the massive sulfides. The quartz-pyrite stockwork is surrounded by a $10-50 \mathrm{~m}$ wide marginal zone, consisting of moderately silicified and chloritized basalts with locally preserved primary textures, similar to the chloritized basalt breccias at TAG. A much wider peripheral zone of weak clay alteration extends up to $100 \mathrm{~m}$ beyond the alteration pipe. In the core of the pipe, subvertical zones of intense chlorite-pyrite alteration occur 50-100 m below the paleoseafloor. The chlorite alteration in the core of the pipe is notably Fe-rich in comparison to alteration at the margins of the pipe (Lydon and Galley, 1986). Reddish to purple lavas (hematized) found outside the alteration pipe were interpreted by Lydon (1984a) to represent the effects of oxidized meteoric groundwaters in barren lavas surrounding the deposits. However, similar hematitic staining is evident in the section at TAG, suggesting that this alteration may also be a seafloor phenomenon.

In contrast to Mathiati, the alteration at Skouriotissa expands downward from a pipe-like body at about $100 \mathrm{mbsf}$ into a laterally extensive quartz-chlorite-pyrite zone about 200-300 $\mathrm{m}$ below the paleoseafloor. The deeper alteration zone is at least 2-3 times wider than the deposit and contains a substantial volume of disseminated pyrite as impregnations within the intensely altered lavas (Kortan, 1970). This pyrite initially replaces primary igneous phases and locally completely overprints the altered basalt. Much of the pyrite appears to have formed early in the history of the deposit, prior to the highest-temperature upflow, and is locally replaced by later chalcopyrite. Epidote first appears below the deposit at a depth of about $250 \mathrm{~m}$, and at $300-400 \mathrm{~m}$ the alteration zone is at least a kilometer 

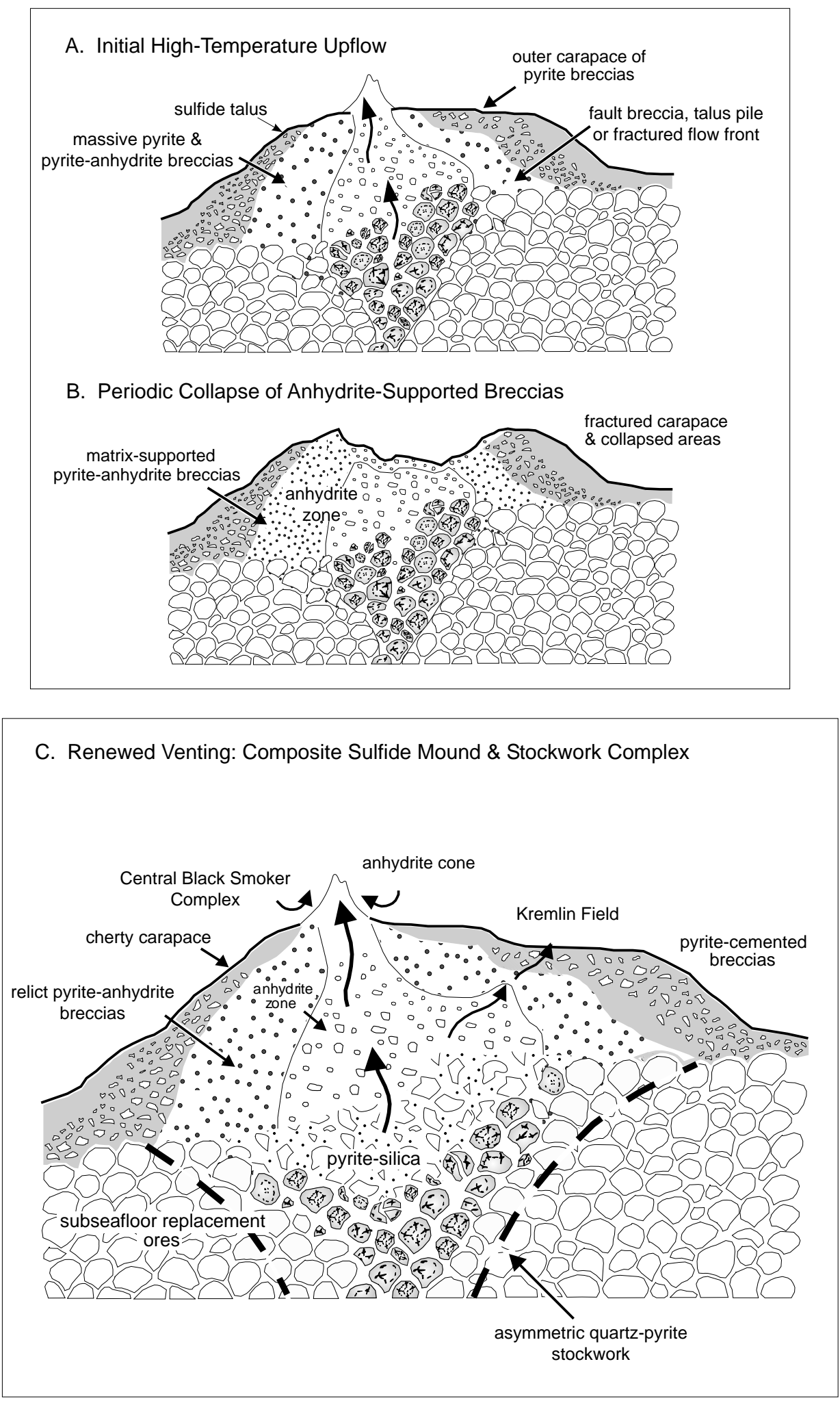

Figure 14. Model for the development of a Cyprus-type mound-stockwork complex based on observations at TAG. A. Growth of a large mound-like sulfide deposit occurs by a combination of accumulating sulfide talus and mineralization and replacement within the mound during a phase of high-temperature hydrothermal venting. Pre-existing sulfide breccias undergo extensive recrystallization and partial replacement by quartz at the top of the stockwork. Entrainment of seawater induces multiple stages of vein-filling and cementation of breccias by anhydrite in the interior of the mound. B. Collapse of anhydrite-supported breccias in the central portion of the mound occurs during intervals of inactivity, leading to the formation of new breccias. C. Focusing of renewed hydrothermal activity through collapse features and development of new fluid pathways through earlier breccias (present state of the TAG mound/stockwork complex). 
wide. Discontinuous zones of chlorite-pyrite and epidote-chlorite alteration also occur at depths of greater than $1 \mathrm{~km}$ beneath many of the other deposits, and this alteration is commonly rooted in the underlying sheeted dikes or intrusive complexes (i.e., metal-depleted root zones: Schiffman and Smith, 1988; Nehlig and Juteau, 1988a,b; Koski et al., 1990; Nehlig et al., 1994). The characteristics of this deep footwall alteration in ophiolites and at the modern seafloor have been discussed extensively in the literature (e.g., Richardson et al., 1987; Stakes and O'Neil, 1982; Stakes and Taylor, 1992; Haymon et al., 1989; Harper et al., 1988; Gillis and Robinson, 1988). Similar alteration was expected at TAG, but drilling during Leg 158 did not penetrate deeply enough to intersect the bottom of the upflow zone. Discontinuous epidote alteration at depth could be indicated by the broad zone of demagnetization encompassing the hydrothermal field.

\section{Metalliferous Sediments and Red Cherts}

Ferruginous cherts or red jaspers are well known in the pillow sequences of the Troodos ophiolite, and especially in close proximity to the massive sulfide deposits. The abundance of red chert in pillow lavas well away from the massive sulfides, suggests that they may be products of low-temperature hydrothermal activity associated with the initial eruption of pillow lavas. Many of the jaspers contain abundant radiolarians and appear to have been contemporaneous with normal pelagic sedimentation. Richards and Boyle (1986) have clearly demonstrated that the interpillow jaspers originated mainly as finegrained, Fe-oxide muds and were later silicified by low-temperature hydrothermal venting during the accumulation of the volcanic pile or within the high-temperature upflow zones associated with later mineralized stockworks. The idea that the red cherts formed by diffuse venting through pre-existing $\mathrm{Fe}$-oxide sediments contrasts with the common interpretation of this material as a primary chemical precipitate or fall-out from a hydrothermal plume. The jaspers are locally interbedded with detrital sulfides and can form an apron, several tens of meters wide, surrounding the massive sulfide deposits, similar to the bright red Fe-oxide muds surrounding the TAG mound. Lydon (1984b) noted that the conglomeratic ores at Mathiati locally grade upward into jasper conglomerate at the top of the deposit, suggesting that red jaspers were forming on or within the mound. At Aarja and Lasail, the massive sulfide lenses are interlayered with hematitic and magnetite-bearing cherts at the flanks of the deposits (Koski et al., 1990). Koski and Haymon (1988) suggested that these sediments may be hydrothermal precipitates from a dense brine, however, they locally bear a strong resemblance to the detrital Fe-oxide sediments at TAG. In places there is clear evidence that later sulfides have replaced the metalliferous sediments.

Red cherts recovered in drill core close to the basalt-sulfide contact at TAG suggest that similar low-temperature, diffuse flow occurred at the periphery of the early mound-stockwork complex. Fragments of red chert in the stockwork zone indicate that exhalative mineralization was likely widespread at the seafloor early in the history of the TAG field (possibly when this section of basalts was much closer to the ridge axis).

The massive sulfides at Cyprus are commonly overlain by dark brown to black manganiferous sediments known as umbers. The umbers may be laterally extensive away from the deposits, and some are not obviously related to sulfide mineralization (e.g., Robertson and Boyle, 1983). They form mainly as chemical precipitates at low-temperature seeps, usually as Fe-Mn oxide crusts or mounds, similar to those found in the Mir and Alvin zones. The Mir zone is presently being buried by the modern equivalent of umbers, and black cherty deposits have formed from the late-stage silicification of the Mn-oxide crusts (e.g., Rona et al., 1993a). Similar manganiferous oxides are unlikely to form at the surface of the TAG mound, as they are more closely associated with sustained fluxes of much lower-temperature fluids. However, such deposits may form as the mound moves farther off-axis and the hydrothermal upflow gradually cools. Any earlier deposits of Mn oxides would have been destroyed by the most recent episodes of high-temperature hydrothermal activity. Manganese concentrations in the drill core are at or below detection limits in nearly all of the samples analyzed (Hannington et al., Chap. 2, this volume).

\section{Development of Gossans}

A characteristic feature of the TAG mound is the extensive seafloor oxidation of sulfide debris on the surface of the deposit (Thompson et al., 1988; Hannington et al., 1988; Hannington et al., 1990a, 1990b; Herzig et al., 1991). Similar ocherous Fe-oxide deposits have been reported from $13^{\circ} \mathrm{N}$ at the East Pacific Rise (Fouquet et al., 1988, 1993) and at Green Seamount (Alt et al., 1987; Alt, 1988a, 1988b). However, drilling indicates that the oxidized portion of the mound is less than a few meters thick. The gossans are developed mainly above the cherty units, and massive pyrite breccias were encountered at relatively shallow depths beneath the oxidized ores $(<5$ mbsf). So far, seafloor oxidation appears to have been limited to the exposed sulfides above the more compact ores, and the penetration of seawater into the underlying massive sulfides does not appear to have produced a deep weathering profile.

Many of the sulfide deposits of Cyprus are capped by similar gossans, that are buried by Cretaceous pillow lavas or sediments (e.g., Skouriotissa, North Mathiatis, Mousoulos: Robertson, 1976; Robertson and Boyle, 1983). The Fe-rich deposits are collectively referred to as ochers, but they may range in composition from fine-grained $\mathrm{Fe}$ oxide sediments (goethite and limonite), to hematitic or magnetitebearing sediments, and jarosite-rich deposits. The ochers are widely recognized as products of submarine weathering (e.g., Constantinou and Govett, 1973), although similar Fe-oxide gossans also have formed as a result of present-day weathering of the deposits on land (cf. Lydon, 1984a). The ochers are up to several meters thick and normally do not extend beyond the limits of the ore bodies. The gossans sometimes rest on altered and mineralized pillow lavas adjacent to the deposits, and these may represent weathered sulfide debris eroded from the adjacent sulfide mounds. Bedded ochers, which locally contain graded units of detrital sulfides and jarosite, together with amorphous Fe oxides, are considered to be the closest analogs of the gossans presently forming on the TAG mound (Herzig et al., 1991).

The gossanous caps on many of the Cyprus deposits were extensively mined for precious metals. Oxidized zones in some of the deposits in Oman are also currently being developed for gold (e.g., Rakah: Table 1). Although much of this gold is related to near-surface supergene processes, Hannington et al. (1988) and Herzig et al. (1991) noted that seafloor weathering on the Cretaceous ocean floor may have been responsible for much of the gold enrichment in the Cyprus ochers. The substantial amount of secondary gold in the gossan at the surface of the TAG mound (up to $20 \mathrm{ppm} \mathrm{Au}$ ), together with abundant secondary $\mathrm{Cu}$ sulfides, native $\mathrm{Cu}$, atacamite and jarosite, provided the first evidence for the supergene enrichment of gold and copper at the seafloor.

In Cyprus, weathering of sulfides also has caused intense alteration at the contact with the underlying basalt. Distinctive red clays are common at the top of the pillow sequence in proximity to the massive sulfides in Cyprus, and they constitute mappable units in some deposits (e.g., Limni: Adamides, 1987; Hadjistavrinou and Constantinou, 1982). The alteration has been ascribed to leaching by nearsurface groundwaters (e.g., Lydon, 1984a), although similar red clays were found in drill core immediately beneath the massive sulfides at the eastern edge of the TAG mound. This observation suggests that the acid alteration in the Cyprus deposits may have occurred at the seafloor where the overlying sulfides were exposed to oxidizing seawater. Acid leaching caused by the oxidation of disseminated pyrite 
Figure 15. Grade-tonnage plot for $\mathrm{Cu}$ in Cyprus-type massive sulfide deposits. The TAG mound-stockwork complex is shown by the star. Data and sources are listed in Table 1.

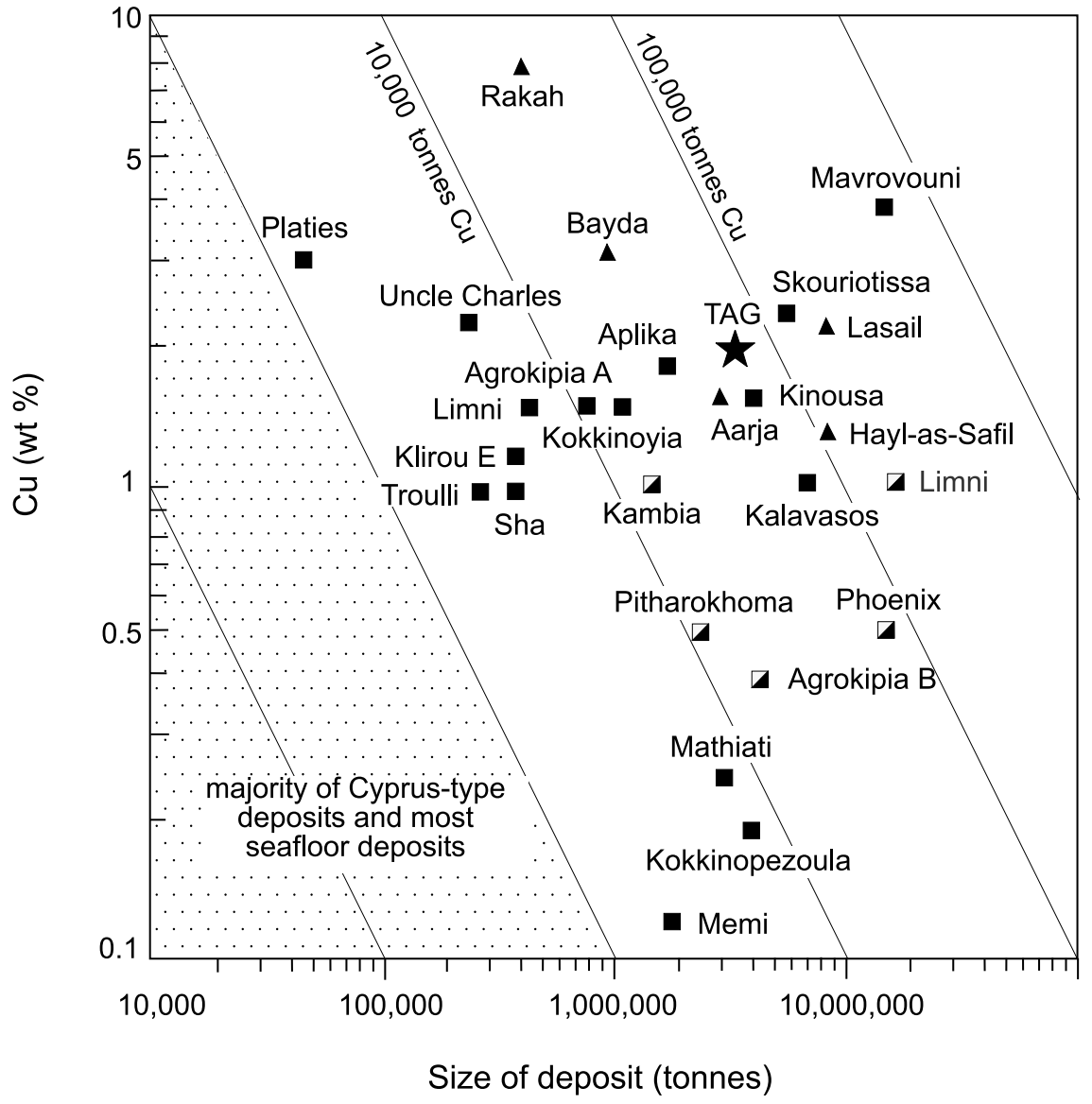

suggest that deposits much larger than TAG (e.g., the 15 million $t$ Mavrovouni deposit) may be forming on the modern seafloor in similar environments (Cox and Singer, 1986). Such deposits have either not been yet been found or are known but not yet adequately delineated (e.g., Southern Explorer Ridge, $86^{\circ} \mathrm{W}$ Galapagos Rift, $13^{\circ} \mathrm{N}$ East Pacific Rise: see Hannington et al., 1995a). The presence of up to four TAG-sized mounds in the Mir and Alvin zones, suggests that the entire TAG Field $(5 \times 5 \mathrm{~km})$ could contain at least 20 million t of massive sulfide, which would be comparable to a large mining lease in Cyprus. The size of the TAG deposit, in comparison to other midocean ridge massive sulfides, may be related to the slow-spreading rate of the ridge and the position of the deposit well off-axis (i.e., where it is not subject to the extensive fissuring that occurs along the axis of the rift valley). The apparently long-lived boundary faults at this location, which have controlled the location of off-axis dike injections and small pillow volcanoes, may also have helped to stabilize hydrothermal upflow.

The processes of mineralization operating at TAG are clearly similar to those of ancient ophiolite-hosted deposits, but it may be important not to lose sight of the fact that few, if any, ophiolite-hosted massive sulfides formed at true mid-ocean ridges. Although there are close comparisons with the cupriferous pyrite deposits in Cyprus, important differences in the morphology, style of mineralization, and bulk composition among deposits in other ophiolites (e.g., Oman, Josephine) caution against the general application of a TAG-Cyprus model to all ophiolite-hosted massive sulfides. On the other hand, many of the observations concerning the development of the moundstockwork complex may have applicability to other massive sulfideforming environments that exhibit similar ore textures (e.g., Kurokotype massive sulfides). 


\section{Growth Rate of the Deposits}

The estimated size and age of the TAG mound permit an assessment of the rate of growth of the deposit. A partial chronology of hydrothermal, volcanic, and tectonic events in the TAG hydrothermal field indicates a complex evolutionary history lasting more than 100 k.y. (Lalou et al., 1995). The oldest sulfides recovered from the deposit have ages of between 40 and $56 \mathrm{ka}$, based on U/Th decay series, and there is evidence for intermittent periods of high-temperature activity over the past 25 k.y. (Lalou et al., 1990, 1993). Although the present mound may be as old as $50 \mathrm{ka}$, it has likely been active for only about $10 \%$ of this time, and long periods of inactivity account for the abundance of oxidized talus on the surface of the mound. If we assume a cumulative output of high-temperature fluids lasting about $5 \mathrm{k} . \mathrm{y}$., the average growth rate of the deposit would be 500 to $1,000 \mathrm{t} / \mathrm{yr}$. This estimate is consistent with calculations based on the fluid fluxes from black smoker vents and the heat output of other productive hydrothermal fields (e.g., Converse et al., 1984; Cann et al., 1986). The central Black Smoker Complex alone is estimated to contain about 30,000 to 50,000 t of massive pyrite, chalcopyrite and anhydrite and, at a rate of 500 to $1,000 \mathrm{t} / \mathrm{yr}$, this edifice may have grown within the last $50 \mathrm{yr}$.

\section{Role of Anhydrite in Deposit Growth}

The abundance of anhydrite at TAG is a product of the enormous hydrothermal flux centered on the Black Smoker Complex. Heating of seawater that is drawn into the mound has produced a $15-20 \mathrm{~m}$ thick zone of massive anhydrite immediately beneath the Black Smoker Complex. At the surface, the upflow zone is capped by a massive anhydrite cone that supports the black smoker chimneys. The presence of a large volume of anhydrite both in the core of the deposit and as massive veins in the underlying stockwork raises questions about the ability of the system to sustain high-temperature upflow near the surface, given the requirement for entrainment of cold seawater below the seafloor to form this anhydrite.

The mound contains an estimated 165,000 t of massive anhydrite, which has been deposited over the last few thousand years of hightemperature upflow. This mass of anhydrite requires the equivalent of at least $4 \times 10^{10} \mathrm{~kg}$ of seawater to account for all the $\mathrm{CaSO}_{4}$ deposited. By comparison, the mass of hydrothermal fluid feeding the Black Smoker Complex is on the order of $10^{9} \mathrm{~kg}$ every year (e.g., assuming that the Black Smoker Complex operates at about $100 \mathrm{~kg} / \mathrm{s}$ ). Despite the large amount of anhydrite deposited, the volume of seawater entrained below the Black Smoker Complex is small compared to the total mass flux of hydrothermal fluids. The fact that the black smoker fluids have not been cooled significantly prior to venting suggests that relatively little mixing with seawater has occurred in the anhydrite zone and that most of the anhydrite is precipitated simply by conductive heating of the entrained seawater at the margins of high-temperature feeder veins. In contrast, mixing may be important beneath the white smokers, and depletions of $\mathrm{Ca}$ in the white smoker vent fluids indicate that about $14 \%$ seawater is incorporated in the lower-temperature upflow (Tivey et al., 1995).

Although the black smoker fluids have not been affected by mixing in the high-temperature zone, reaction with pre-existing anhydrite may have a small but measurable impact on the chemistry of the vent fluids. Isotopic effects related to the reduction of $\mathrm{SO}_{4}$ are evident in the bulk $\delta^{34} \mathrm{~S}$ of the sulfides, and oxidation of the fluids may account for high $\mathrm{fS}_{2}-\mathrm{fO}_{2}$ mineral assemblages in the black smokers (e.g., Janecky and Shanks, 1988; Tivey et al., 1995).

Anhydrite is not well preserved in fossil deposits, owing to its retrograde solubility. Gypsum is present locally in many Cyprus-type deposits, although it is thought to have formed mainly by recent oxidation of sulfides by meteoric groundwaters (Lydon, 1984a). Semimassive gypsum and anhydrite does occur beneath some of the Kuro- ko deposits in Japan (e.g., Sato, 1974; Shikazono et al., 1983; Kuroda, 1983). Pyrite-anhydrite ores (known as "sekko") locally underlie the massive sulfides, and several deposits contained between 100,000 and 1,000,000 t of gypsum ore (e.g., Matsumine-Shakanai area). The observations at TAG show that heating of a small amount of entrained seawater to high temperatures within the upflow zone could easily account for this amount of anhydrite. The sekko ore is commonly $<10 \mathrm{~m}$ thick but is underlain by a zone of nodular anhydrite that cements deposits of tuff breccia in the footwall of the massive sulfides. Fluid inclusions in the anhydrite homogenize at temperatures up to $340^{\circ} \mathrm{C}$, confirming that the anhydrite-rich zones formed mainly at high-temperatures (Shikazono et al., 1983). Distinctive, "powdery" yellow ore also occurs at the top of the quartz-rich stockworks and below a zone of compact massive sulfide ore. This ore is porous and weakly consolidated and may have originated through the dissolution of anhydrite cement in a manner similar to the sandy pyrite at TAG. In the Hanaoka deposits, large anhydrite veins in the footwall of the massive sulfides may also have developed at the margins of high-temperature fluid conduits similar to those at TAG. Similar occurrences of semi-massive anhydrite are known in other Phanerozoic massive sulfide deposits (e.g., Steefel, 1987), but it is not immediately apparent why the anhydrite-rich ores have been preserved in some deposits but not in others. In the Kuroko deposits, the massive sulfides are overlain by extensive baritic caps, cherty exhalites, and mudstones that may have contributed to the preservation of the anhydrite.

The importance of anhydrite at TAG substantiates a model for the formation of seafloor sulfide deposits originally outlined in Goldfarb et al. (1983) and Campbell et al. (1984). They postulated the existence of an anhydrite cap above the high-temperature vents that traps the hydrothermal fluids and allows for the accumulation of metals at the seafloor. By analogy with black smoker chimneys, they predicted that breccia ores would form when the anhydrite cap collapses under its own weight. They also recognized that anhydrite is not a common constituent of most fossil sulfide deposits and argued that the anhydrite cap was dissolved as fluids convecting through the sulfide deposit cooled.

\section{The Origin of Breccia Ores}

Early interpretations of the origin of conglomeratic ores and related breccias of the Cyprus deposits appealed to seafloor weathering and acid leaching of the sulfides (Constantinou, 1976). Lydon (1984b) suggested that the breccia ores were mainly accumulations of sulfide debris produced by the erosion of steep-sided mounds or adjacent to synvolcanic faults. Lydon and Galley (1986) also suggested that some brecciation may have been caused by explosive hydrothermal eruptions. Observations at TAG confirm that much of the sandy pyrite and conglomeratic sulfides on top of the deposits are likely products of the collapse of sulfide edifices and mass wasting of the mounds. Because the TAG mound has formed in an area of relatively low relief, most of the sulfide talus has developed in situ, rather than by transport as debris flows. The collapse of the anhydritesupported portion of the mound following major episodes of hydrothermal upflow also has caused extensive in situ brecciation of the mound and this is interpreted to have been an important mechanism for the formation of "breccia ores" in other seafloor sulfide deposits. The frequent collapse anhydrite-supported breccias may also contribute to the observed flattening of the upper surfaces of many of the mounds. Textures similar to those observed in the active TAG mound are common in many ancient massive sulfides and may offer clues to the former presence of an anhydrite-rich matrix that is no longer preserved.

Anhydrite is virtually absent in massive sulfide deposits that formed in the middle to late Archean, such as those in the Canadian Shield. Because of the generally reduced nature of the Precambrian 
oceans, little or no $\mathrm{SO}_{4}$ was available to make anhydrite in these deposits. It is noteworthy that much of the fragmental ore in deposits of this age consists of sulfide clast-bearing debris flows, talus breccias, or products of hydrothermal explosion, whereas the interiors of the deposits typically consist of massive banded sulfides formed as coherent lenses at the seafloor or as replacements of permeable volcanic units (e.g., Franklin et al., 1981). In the absence of an anhydritesupported vent complex, as at TAG, the development of extensive collapse breccias within the mound seems unlikely. Anhydrite is also unlikely to have been an important mineral in a large number of ancient massive sulfide deposits thought to have formed in reduced, anoxic basins. This may account for the absence of fragmental ores or coarse, conglomeratic breccias in some of the ophiolite-hosted deposits of Oman.

\section{Importance of Subseafloor Stockwork Mineralization}

The largest of the deposits in Cyprus are mainly subseafloor stockworks, locally occupying more than 15 million $t$ of mineralized rock (e.g., Limni). Where both massive sulfides and stockwork mineralization are present, the stockwork zones can account for $30 \%-$ $40 \%$ of the total metal, despite lower grades than in the massive sulfides (e.g., Agrokipia A and B). These observations confirm that a large proportion of the metal in modern hydrothermal systems never reaches the seafloor, and the surface expression of a deposit may be small in comparison to the total tonnage of mineralized rock. At TAG, the stockwork zone accounts for about $30 \%$ of the mineralization and contains an estimated $15 \%-20 \%$ of the $\mathrm{Cu}$ metal.

\section{Metal Zoning and Implications for Zone Refining}

Strong metal enrichment in the TAG mound is restricted to the upper $5 \mathrm{~m}$ of the deposit. This is similar to the strong co-enrichment of $\mathrm{Cu}$ and $\mathrm{Zn}$ observed at the top of many Cyprus-type deposits (e.g., Kokkinoyia, Skouriotissa, Mathiati). The absence of sphalerite in the interior of many Cyprus-type deposits suggests that they have been extensively reworked in the same manner as the TAG mound and that $\mathrm{Zn}$ (and to a lesser extent $\mathrm{Cu}$ ) have been stripped from the underlying massive sulfides and remobilized to the tops of the deposits. This process of "zone refining" was first proposed for seafloor deposits by Goldfarb et al. (1983), Hekinian et al. (1985) and Hekinian and Fouquet (1985), and a similar model was described by Eldridge et al. (1983) for the Kuroko massive sulfides. Drilling of the TAG mound demonstrates confirms that zone refining was likely responsible for the strong enrichment of $\mathrm{Zn}$ and other metals in the outer portions of the deposit (see also Edmond et al., 1995). In this model, low-temperature minerals precipitated at an early stage in the development of the mound are continuously remobilized to the top of the deposit. These constituents are reprecipitated in veins or open spaces close to the seafloor and in low-temperature white smokers such as the chimneys in the Kremlin field. Virtually all of the $\mathrm{Zn}, \mathrm{Ag}, \mathrm{Pb}$, and $\mathrm{Au}$ in the deposit are contained in the top $5 \mathrm{~m}$ of the mound, and any new metal added by high-temperature end-member fluids will eventually end up in the outermost $\mathrm{Zn}$-rich portion of the deposit. Retrograde cooling, during the collapse of hydrothermal upflow may promote lowtemperature mineralization in the remaining open spaces of the mound, and $\mathrm{Zn}$-rich sulfides formerly precipitated at white smoker chimneys at the surface may be deposited in deeper veins within the core of the deposit. Although zone refining has significantly enriched certain metals in the uppermost sulfides, this process also serves to deplete metals in the sulfides deposited beneath the seafloor. By analogy with the Cyprus deposits, the gradual stripping of $\mathrm{Cu}$ and $\mathrm{Zn}$ from the lower part of the mound at TAG (i.e., "over refining") will eventually leave behind a barren pyrite body similar to the many subeconomic pyrite deposits found in the Troodos ophiolite.

\section{ACKNOWLEDGMENTS}

This review has benefited from discussions with I.R. Jonasson, R. Koski, and D. Ames. Comments by R. Zierenberg, T. Urabe, and R. Newberry, as well as editorial suggestions by L. Stokking, substantially improved earlier versions of this manuscript. This is a product of NATO Grant CRG 941218, and GSC Contribution No. 1996368.

\section{REFERENCES}

Adamides, N.G., 1980. The form and environment of formation of the Kalavasos ore deposits-Cyprus. In Panayiotou, A. (Ed.), Ophiolites: Proceedings of the International Symposium, 1979. Geol. Surv. Dep. Cyprus, $117-127$

, 1984. Cyprus volcanogenic sulfide deposits in relation to their environment of formation [Ph.D. thesis]. Univ. of Leicester.

, 1987. Diverse modes of occurrence of Cyprus sulphide deposits and comparison with recent analogues. In Robinson, P.T., Gibson, I.L., and Panayiotou, A. (Eds.), Cyprus Crustal Study Project: Initial Report, Holes CY-2 and 2a. Pap.-Geol. Surv. Can., 85-29:153-168.

Alabaster, T., Pearce, J.A., Mallick, D.I.J., and Elboushi, I.M, 1980. The volcanic stratigraphy and location of massive sulphide deposits in the Oman Ophiolite. In Panayiotou, A. (Ed.), Ophiolites, Proceedings of the International Ophiolite Symposium, 1979. Geol. Surv. Dep. Cyprus, 751-757.

Alt, J.C., 1988a. The chemistry and sulfur isotope composition of massive sulfide and associated deposits on Green Seamount, Eastern Pacific. Econ. Geol., 83:1026-1033.

, 1988b. Hydrothermal oxide and nontronite deposits on seamounts in the Eastern Pacific. Mar. Geol., 81:227-239.

Alt, J.C., Lonsdale, P., Haymon, R., and Muehlenbachs, C., 1987. Hydrothermal sulfide and oxide deposits on seamounts near $21^{\circ} \mathrm{N}$, East Pacific Rise. Geol. Soc. Am. Bull., 98:157-168.

Auclair, G., Fouquet, Y., and Bohn, M., 1987. Distribution of selenium in high-temperature hydrothermal sulfide deposits at $13^{\circ} \mathrm{N}$, East Pacific Rise. Can. Mineral., 25:577-588.

Batchelor, D.A.-F., 1992. Styles of metallic mineralization and their tectonic setting in the Sultanate of Oman. Trans. Inst. Min.Metall., 101:B108B 120.

Bear, L.M., 1963. The Mineral Resources and Mining Industry of Cyprus. Cyprus Geol. Surv. Dep. Bull., 1.

Becker, K., and Von Herzen, R.P., 1996. Pre-drilling observations of conductive heat flow at the TAG active mound using Alvin. In Humphris, S.E., Herzig, P.M., Miller, D.J., et al., Proc. ODP, Init. Repts., 158: College Station, TX (Ocean Drilling Program), 23-29.

Bluth, G.J., and Ohmoto, H., 1988. Sulfide-sulfate chimneys on the East Pacific Rise, $11^{\circ}$ and $13^{\circ} \mathrm{N}$ latitude. Part II: sulfur isotopes. Can. Mineral., 26:505-515.

Calvez, J.Y., and Lescuyer, J.L., 1991. Lead isotope geochemistry of various sulphide deposits from the Oman Mountains. In Peters, T., Nicolas, A., and Coleman, R.G. (Eds.), Ophiolite Genesis and Evolution of the Oceanic Lithosphere. Ministry of Petroleum and Minerals, Sultanate of Oman, 385-397.

Cameron, W.E., 1985. Petrology and origin of primitive lavas from the Troodos ophiolite, Cyprus. Contrib. Mineral. Petrol., 89:239-255.

Campbell, I.H., McDougall, T.J., and Turner, J.S., 1984. A note on fluid dynamic processes which can influence the deposition of massive sulfides. Econ. Geol., 79:1905-1913.

Cann, J.R., Strens, M.R., and Rice, A., 1986. A simple magma-driven thermal balance model for the formation of volcanogenic massive sulphides. Earth Planet. Sci. Lett., 76:123-134.

Coleman, R.G., 1981. Tectonic setting for ophiolite obduction in Oman. $J$. Geophys. Res., 86:2497-2508.

Coleman, R.G., et al., 1979. The Semail ophiolite and associated massive sulfide deposits, Sultanate of Oman, In Al-Shanti, A.M.S. (Ed.), Evolution and Mineralization of the Arabian-Nubian Shield (Vol. 2). I.A.G. Bull., 3:179-192.

Collinson, T.B., 1986. Hydrothermal mineralization and basalt alteration in stockwork zones of the Bayda and Lasail massive sulfide deposits, Oman ophiolite [M.Sci. thesis]. Univ. of California, Santa Barbara.

Constantinou, G., 1972. The geology and genesis of the sulphide ores of Cyprus [Ph.D. thesis]. Univ. of London. 
1973. Geology, geochemistry, and genesis of Cyprus sulphide deposits. Econ. Geol., 68:843-858.

, 1976. Genesis of the conglomerate structure, porosity and collomorphic textures of the massive sulphide ores of Cyprus. Geol. Assoc. Can., Spec. Pap., 14:187-210.

, 1980. Metallogenesis associated with the Troodos ophiolite. In Panayioutou, A. (Ed.), Ophiolites. Proc. Int. Ophiolite Symp. Cyprus, Cyprus Geol. Surv. Dep., 663-674.

Constantinou, G., and Govett, G.J.S., 1972. Genesis of sulphide deposits, ochre and umber of Cyprus. Trans. Inst. Min. Metall., 81:B34-B46.

1973. Geology, geochemistry, and genesis of Cyprus sulfide deposits. Econ. Geol., 68:843-858.

Converse, D.R., Holland, H.D., and Edmond, J.M., 1984. Flow rates in the axial hot springs of the East Pacific Rise $\left(21^{\circ} \mathrm{N}\right)$ : implications for the heat budget and the formation of massive sulfide deposits. Earth Planet. Sci. Lett., 69:159-175.

Cox, D.P., and Singer, D.A. (Eds.), 1986. Mineral Deposit Models. U.S. Geol. Surv. Bull., 1693.

Edmond, J.M., Campbell, A.C., Palmer, M.R., German, C.R., Klinkhammer, G.P., Edmonds, H.N., Elderfield, H., Thompson, G., and Rona, P., 1995. Time-series studies of vent fluids from the TAG and MARK sites (1986, 1990): Mid-Atlantic Ridge: a new solution chemistry model and a mechanism for $\mathrm{Cu} / \mathrm{Zn}$ zonation in massive sulfide ore bodies. In Parson, L.M., Walker, C.L., and Dixon, D.R. (Eds.), Hydrothermal Vents and Processes. Geol. Soc. Spec. Publ. London, 87:77-86.

Eldridge, C.S., Barton, P.B., Jr., and Ohmoto, H., 1983. Mineral textures and their bearing on formation of the Kuroko orebodies. In Ohmoto, H., and Skinner, B.J. (Eds.), The Kuroko and Related Volcanogenic Massive Sulfide Deposits. Econ. Geol. Monogr., 5:241-281.

Embley, R.W., Jonasson, I.R., Perfit, M.R., Franklin, J.M., Tivey, M.A., Malahoff, A., Smith, M.F., and Francis, T.J.G., 1988. Submersible investigation of an extinct hydrothermal system on the Galapagos Ridge: sulfide mounds, stockwork zone, and differentiated lavas. Can. Mineral., 26:517-539.

Fleet, A.J., and Robertson, A.H.F., 1980. Ocean-ridge metalliferous and pelagic sediments of the Semail Nappe, Oman. J. Geol. Soc. Lond., 137:403-422.

Fouquet, Y., Auclair, G., Cambon, P., and Etoubleau, J., 1988. Geological setting and mineralogical and geochemical investigations on sulfide deposits near $13^{\circ} \mathrm{N}$ on the East Pacific Rise. Mar. Geol., 84:143-178.

Fouquet, Y., Wafik, A., Cambon, P., Mevel, C., Meyer, G., and Gente, P., 1993. Tectonic setting and mineralogical and geochemical zonation in the Snakepit sulphide deposit (Mid-Atlantic Ridge at $23^{\circ} \mathrm{N}$ ). Econ. Geol., 88:2018-2036.

Franklin, J.M., Lydon, J.W., and Sangster, D.F., 1981. Volcanic-associated massive sulfide deposits. Econ. Geol., 75th Anniv. Vol., 75:485-627.

Gibson, H., and Koski, R.A., 1995. Volcanic setting of the Aarja massive sulfide deposit in the Semail ophiolite, northern Oman. Eos, 76:641.

Gillis, K.M., and Robinson, P.T., 1988. Distribution of alteration zones in the upper oceanic crust. Geology, 16:262-266.

Goldfarb, M.S., Converse, D.R., Holland, H.D., and Edmond, J.M., 1983. The genesis of hot spring deposits on the East Pacific Rise, $21^{\circ} \mathrm{N}$. Econ. Geol. Monogr., 5:184-197.

Hadjistavrinou, Y., and Constantinou, G., 1982. Cyprus. In Dunning, F.W., Mykura, W., and Slater, D. (Eds.), Mineral Deposits of Europe (Vol. 2): Southeast Europe. Mineral. Soc., Inst. Min. Metall., 255-277.

Hall, J.M., Walls, C.C., and Yang, J.-S., 1989. Constructional features of the Troodos ophiolite and implications for the distribution of orebodies and the generation of oceanic crust. Can. J. Earth Sci., 26:1172-1184.

Hannington, M.D., 1993. The formation of atacamite during weathering of sulfides on the modern seafloor. Can. Mineral., 31: 945-956.

Hannington, M.D., Hall, G.E.M., and Vaive, J., 1990a. Acid pore fluids from an oxidizing sulfide deposit on the Mid-Atlantic Ridge: implications for supergene enrichment of gold on the seafloor. Geol. Soc. Am. Ann. Meeting, Progr. Abstr., 22:A42.

Hannington, M.D., Herzig, P.M., Scott, S.D., Thompson, G., and Rona, P.A., 1991. Comparative mineralogy and geochemistry of gold-bearing sulfide deposits on the mid-ocean ridges. Mar. Geol., 101:217-248.

Hannington, M.D., Herzig, P.M., Thompson, G., and Rona, P.A., 1990 b. Metalliferous sulfide-oxide sediments from the TAG Hydrothermal Field, $26^{\circ} \mathrm{N}$, Mid-Atlantic Ridge. Eos, 71:1653.

Hannington, M.D., Jonasson, I.R., Herzig, P.M., and Petersen, S., 1995a. Physical, chemical processes of seafloor mineralization at mid-ocean ridges. In Humphris, S.E., et al. (Eds.), Seafloor Hydrothermal Systems: Physical, Chemical, Biological and Geological Interactions. Am. Geophys. Union Monogr., 91:115-157.

Hannington, M.D., and Scott, S.D., 1989. Sulfidation equilibria as guides to gold mineralization in volcanogenic massive sulfides: evidence from sulfide mineralogy and the composition of sphalerite. Econ. Geol., 84:1978-1995.

Hannington, M.D., Thompson, G., Rona, P.A., and Scott, S.D., 1988. Gold and native copper in supergene sulfides from the Mid-Atlantic Ridge. Nature, 333:64-66.

Hannington, M.D., Tivey, M.K., Larocque, A.C.L., Petersen, S., and Rona, P.A., 1995b. The occurrence of gold in sulfide deposits of the TAG hydrothermal field, Mid-Atlantic Ridge. Can. Mineral., 33:1285-1310.

Harper, G.D., 1985. Tectonics of slow spreading mid-ocean ridges and consequences of a variable depth to the brittle/ductile transition. Tectonics, 4:395-409.

Harper, G.D., Bowman, J.R., and Kuhns, R.J., 1988. A field, chemical, and stable isotope study of subseafloor metamorphism of the Josephine Ophiolite, California-Oregon. J. Geophys. Res., 93:4625-4656.

Hawkins, J.W., Bloomer, S.H., Evans, C.A., and Melchior, J.T., 1984. Evolution of intra-oceanic arc-trench systems. Tectonophysics, 102:175-205.

Haymon, R.M., Koski, R.A., and Abrams, M.J., 1989. Hydrothermal discharge zones beneath massive sulfide deposites mapped in the Oman ophiolite. Geology, 17:531-535.

Haymon, R.M, Koski, R.A., and Sinclair, C., 1984. Fossils of hydrothermal vent worms discovered in Cretaceous sulfide ores of the Samail ophiolite, Oman. Science, 223:1407-1409.

Hekinian, R., and Fouquet, Y., 1985. Volcanism and metallogenesis of axial and off-axial structures on the East Pacific Rise near $13^{\circ} \mathrm{N}$. Econ. Geol., 80:221-249.

Hekinian, R., Francheteau, J., and Ballard, R.D., 1985. Morphology and evolution of hydrothermal deposits at the axis of the East Pacific Rise. Oceanol. Acta, 8:147-155.

Herzig, P.M., 1988. A mineralogical, geochemical, and thermal profile through the Agrokipia "B" hydrothermal sulfide deposit, Troodos ophiolite complex, Cyprus. In Friedrich, G.H., and Herzig, P.M. (Eds.), Base Metal Sulfide Deposits in Sedimentary and Volcanic Environments: Berlin (Springer-Verlag), 182-215.

Herzig, P.M., and Hannington, M.D., 1995. Polymetallic massive sulfides at the modern seafloor-a review. Ore Geol. Rev., 10:95-115.

Herzig, P.M., Hannington, M.D., Scott, S.D., Maliotis, G., Rona, P.A., and Thompson, G., 1991. Gold-rich seafloor gossans in the Troodos ophiolite and on the Mid-Atlantic Ridge. Econ. Geol., 86:1747-1755.

Humphris, S.E., Herzig, P.M., Miller, D.J., et al., 1996. Proc. ODP, Init. Repts., 158: College Station, TX (Ocean Drilling Program).

Hurley, T.D., and Crocket, J.H., 1985. A gold-sphalerite association in a volcanogenic massive sulfide deposit near Tilt Cove, Newfoundland. Can. Mineral., 23:423-430.

Hutchinson, R.W., 1965. Genesis of Canadian massive sulfides reconsidered by comparison to Cyprus deposits. Trans. Can. Inst. Min. Metall., 58:286-300.

1973. Volcanogenic massive sulfide deposits and their metallogenic significance. Econ. Geol., 68:1223-1246.

Hutchinson, R.W., and Searle, D.L., 1970. Stratabound pyrite deposits in Cyprus and relations to other sulfide ores. Soc. Min. Geol. Jpn. Spec. Iss., 3:198-205.

Ixer, R.A., Alabaster, T., and Pearce, J.A., 1984. Ore petrography and geochemistry of massive sulphide deposits within the Semail Ophiolite, Oman. Trans. Min. Metall., Sect. B, 93:B114-B124.

Ixer, R.A., Vaughan, D.J., Pattrick, R.A.D., and Alabaster, T., 1986. Mineralogical studies and their bearing on the genesis of massive sulfide deposits from the Semail ophiolite complex, Oman. In Gallagher, M.J., et al. (Eds.), Metallogeny of Basic and Ultrabasic Rocks. Inst. Min. Metall., 33-48.

Janecky, D.R., and Shanks, W.C., III, 1988. Computational modeling of chemical and sulfur isotopic reaction processes in seafloor hydrothermal systems: chimneys, massive sulfides, and subjacent alteration zones. Can. Mineral., 26:805-825.

Johnson, H.P., Karsten, J.L., Vine, F.J., Smith, G.C., and Schonhartig, G., 1982. A low-level magnetic survey over a massive sulfide ore body in the Troodos ophiolite complex, Cyprus. Mar. Tech. Soc. J., 16:76-80.

Johnson, H.P., and Pariso, J.E., 1987. The effects of hydrothermal alteration on the magnetic properties of oceanic crust: results from drill holes CY-2 
and CY-2a, Cyprus Crustal Study Project. In Robinson, P.T., Gibson, I.L., and Panayiotou, A. (Eds.), Geol. Surv. Can. Pap., 85-29:283-293.

Kappel, E.S., and Franklin, J.M., 1989. Relationships between geologic development of ridge crests and sulfide deposits in the northeast Pacific Ocean. Econ. Geol., 84:485-505.

Karson, J.A., and Rona, P.A., 1990. Block tilting, transfer faults, and structural control of magmatic and hydrothermal processes in the TAG area, Mid-Atlantic Ridge $26^{\circ}$ N. Geol. Soc. Am. Bull., 102:1635-1645.

Kleinrock, M.C., Humphris, S.E., and the Deep-TAG Team, 1996. Detailed structure and morphology of the TAG active hydrothermal mound and its geotectonic environment. In Humphris, S.E., Herzig, P.M., Miller, D.J., et al., Proc. ODP, Init. Repts., 158: College Station, TX (Ocean Drilling Program), 15-21.

Kortan, K., 1970. Zur Bildung der Scwefelkies-Kupferkies-Vorkommem Cyperns unter besonderer Berucksichtigung der Lagerstatte Skouriotissa [Ph.D. thesis]. Techn. Univ. Clusthal, Germany.

Koski, R.A., 1987. Sulfide deposits on the seafloor: geological models and resource perspectives based on studies in ophiolite sequences. In Teleki, P.G., et al. (Eds.), Marine Minerals, Resource Assessment Strategies. Proc. NATO Adv. Res. Workshop, Ser. C, 194:301-316.

Koski, R.A., and Haymon, R.M., 1988. Magnetite-rich metalliferous sediment from the Lasail massive sulfide deposit in the Samail ophiolite, northern Oman. Geol. Soc. Am., Progr. Abstr., 20:173-174.

Koski, R.A., Haymon, R.M., and Stakes, D.S., 1990. Plagiogranites, hydrothermal discharge, and sulphide deposits in the Sohar Mining District, Northern Oman. Field Guide, Excursion E3 Symp. on Ophiolite Genesis and Evolution of Oceanic Lithosphere, Oman, Ministr. Petrol. Miner.

Kuhns, R.J., and Baitis, H.W., 1987. Preliminary study of the Turner Albright $\mathrm{Zn}-\mathrm{Cu}-\mathrm{Ag}-\mathrm{Au}-\mathrm{Co}$ massive sulfide deposit, Josephine County. Ore. Econ. Geol., 82:1326-1376.

Kuroda, H., 1983. Geologic characteristics and formation environments of the Furutobe and Matsuki Kuroko deposits, Akita Prefecture, Northeast Japan. Econ. Geol. Monogr., 5:149-166.

Lalou, C., Reyss, J.L., Brichet, E., Arnold, M., Thompson, G., Fouquet, Y., and Rona, P.A., 1993. New age data for Mid-Atlantic Ridge hydrothermal sites: TAG and Snakepit geochronology revisited. J. Geophys. Res., 98:9705-9713.

Lalou, C., Reyss, J.-L., Brichet, E., Rona, P.A., and Thompson, G., 1995. Hydrothermal activity on a $10^{5}$-year scale at a slow-spreading ridge, TAG hydrothermal field, Mid-Atlantic Ridge $26^{\circ}$ N. J. Geophys. Res., 100:17855-17862.

Lalou, C., Thompson, G., Arnold, M., Brichet, E., Druffel, E., and Rona, P.A., 1990. Geochronology of TAG and Snakepit hydrothermal fields, Mid-Atlantic Ridge: witness to a long and complex hydrothermal history. Earth Planet. Sci. Lett., 97:113-128.

Lescuyer, J.L., Oudin, E., and Beurrier, M., 1988. Review of the different types of mineralization related to the Oman ophiolitic volcanism. Proc. 7th Quadrenniel IAGOD Symp., E. Schweizerbart'sche Verlagsbuchhandl., Stuttgart, 489-500.

Lisitsyn, A.P., Bogdanov, Y.A., Zonenshayn, L.P., Kuz'min, M.I., and Sagalevich, A.M., 1989. Hydrothermal phenomena in the Mid-Atlantic Ridge at Lat. $26^{\circ} \mathrm{N}$ (TAG hydrothermal field). Int. Geol. Rev., 31:1183-1198.

Lydon, J.W., 1984a. Some observations on the mineralogical and chemical zonation patterns of volcanogenic sulphide deposits of Cyprus. Pap.Geol. Surv. Can., 84-1A:611-616.

- 1984b. Some observations on the morphology and ore textures of volcanogenic sulfide deposits of Cyprus. Pap.-Geol. Surv. Can., 841A:601-610.

Lydon, J.W., and Galley, A.G., 1986. The chemical and mineralogical zonation of the Mathiati alteration pipe, Cyprus and its genetic significance. In Gallagher, M.J., Ixer, R.A., Neary, C.R., and Prichard, H.M. (Eds.), Metallogeny of Basic and Ultrabasic Rocks. London Inst. Min. Metall., 46-68.

Metz, S., Trefry, J.H., and Nelson, T.A., 1987. History and geochemistry of a metalliferous sediment core from the Mid-Atlantic Ridge crest, at $26^{\circ} \mathrm{N}$. Geochim. Cosmochim. Acta, 52:2369-2378.

Mills, R., Elderfield, H., and Thompson, J., 1993. A dual origin for the hydrothermal component in a metalliferous sediment core from the MidAtlantic Ridge. J. Geophys. Res., 98:9671-9681.

Miyashiro, A., 1973. The Troodos ophiolitic complex was probably formed in an island arc. Earth Planet. Sci. Lett., 19:218-224.

Mozgova, N., Krasnov, S.G., Batuyev, B.S., Borodaev, Y.S., Efimov, A.V., Markov, V.F., and Stepanova, T.V., 1996. The first report of cobalt pentlandite from a Mid-Atlantic Ridge hydrothermal deposits. Can. Mineral., 34:23-28.
Nehlig, P., and Juteau, T., 1988a. Deep crustal seawater penetration and circulation at ocean ridges: evidence from the Oman Ophiolite. Mar. Geol., $84: 209-228$.

, 1988b. Flow porosities, permeabilities and preliminary data on fluid inclusions and fossil thermal gradients in the crustal sequence of the Sumail ophiolite (Oman). Tectonophysics, 151:199-221.

Nehlig, P., Juteau, T., Bendel, V., and Cotten, J., 1994. The root zone of oceanic hydrothermal systems: constraints from the Samail ophiolite (Oman). J. Geophys. Res., 99:4703-4713.

Nicolas, A., 1995. The Mid-Ocean Ridges: Mountains Below Sea Level: New York (Springer-Verlag).

Oudin, E., 1983. Mineralogie de gisements et indices lies a des zones d'accretion oceaniques actuelles (ride Est Pacific et Mer Rouge) et fossile (Cyphre). Chron. Rech. Min., 470:43-55.

Oudin, E., Bouladon, J., and Paris, J.P., 1985. Vers hydrothermaux fossiles dans une mineralisation sulfure des ophiolites de Nouvelle-Caledonie. $C$. R. Acad. Sci. Ser. 2, 301:157-162.

Oudin, E., and Constantinou, G., 1984. Black smoker chimney fragments in Cyprus sulphide deposits. Nature, 308:349-353.

Panayiotou, A., 1969. The Sha mine. Bull. Geol. Surv. Cyprus, 2:41-56.

Pantazis, T. M., 1967. The geology and mineral resources of the PharmakasKalavasos area. Mem. Geol. Surv. Cyprus, 8.

Paradis, S., Jonasson, I.R., LeCheminant, G.M., and Watkinson, D.H., 1988. Two zinc-rich chimneys from the Plume Site, southern Juan de Fuca Ridge. Can. Mineral., 26:637-654.

Pearce, J.A., Alabaster, T., Shelton, A.W., and Searle, M.P., 1981. The Oman ophiolite as a Cretaceous arc-basin complex: evidence and implications. Philos. Trans. R. Soc. London A, 300:299-317.

Richards, H.G., and Boyle, J.F., 1986. Origin, alteration and mineralization of inter-lava metalliferous sediments of the Troodos Ophiolite, Cyprus. In Gallagher, M.J., Ixer, R.A., Neary, C.R., and Prichard, H.M. (Eds.), Metallogeny of Basic and Ultrabasic Rocks. London Inst. Min. Metall., 21-31.

Richards, H., Cann, J.R., and Jensenius, J., 1989. Mineralogical zonation and metasomatism of the alteration pipes of Cyprus sulfide deposits. Econ. Geol., 84:91-115.

Richardson, C.J., Cann, J.R., Richards, H.G., and Cowan, J.G., 1987. Metaldepleted root zones of the Troodos ore-forming hydrothermal systems, Cyprus. Earth Planet. Sci. Lett., 84:243-253.

Robertson, A.H.F., 1976. Origin of ochres and umbers from Skouriotissa, Troodos Massif, Cyprus. Trans. Inst. Min. Metall., 85:B245-251.

Robertson, A.H.F., and Boyle, J.F., 1983. Tectonic setting and origin of metalliferous sediments in the Mesozoic Tethyan ocean: In Rona, P., et al. (Eds.), Hydrothermal Processes at Seafloor Spreading Centres. NATO Adv. Res. Inst., 595-664.

Rona, P.A., Bogdanov, Y.A., Gurvich, E.G., Rimski-Korsakov, A., Sagalevitch, A.M., Hannington, M.D., and Thompson, G., 1993a. Relict hydrothermal zones in the TAG hydrothermal field, Mid-Atlantic Ridge $26^{\circ} \mathrm{N}$, 45W. J. Geophys. Res., 98:9715-9730.

Rona, P.A., Hannington, M.D., Raman, C.V., Thompson, G., Tivey, M.K., Humphris, S.E., Lalou, C., and Petersen, S., 1993b. Active and relict seafloor hydrothermal mineralization at the TAG hydrothermal field, MidAtlantic Ridge. Econ. Geol., 88:1987-2013.

Rona, P.A., Klinkhammer, G., Nelson, T.A., Trefry, J.H., and Elderfield, H., 1986. Black smokers, massive sulfides and vent biota on the Mid-Atlantic Ridge. Nature, 321:33-37.

Sangster, D.F., 1980. Quantitative characteristics of volcanogenic massive sulphide deposits. Bull. Can. Inst. Min. Metall., 73:74-81.

Santaguida, F., and Hannington, M.D., 1995. Characteristics of gold mineralization in volcanogenic massive sulphide deposits of the Notre Dame Bay area, central Newfoundland. Can. J. Earth Sci., 33:316-334.

Sato, J., 1974. Ores and ore minerals from the Shakanai mine, Akita Prefecture, Japan. Soc. Min. Geol. Jpn., Spec. Iss., 6:323-336.

Schiffman, P., and Smith, B.M., 1988. Petrology and oxygen isotope geochemistry of a fossil seawater hydrothermal system within the Solea Graben, northern Troodos ophiolite, Cyprus. J. Geophys. Res., 93:46124624.

Schiffman, P., Smith, B.M., Varga, R.J., and Moores, E.M., 1987. Geometry, conditions, and timing of off-axis hydrothermal metamorphism and oredeposition in the Solea Graben. Nature, 325:423-425.

Searle, D.L., 1972. Mode of occurrence of the cupriferous pyrite deposits of Cyprus. Trans. Inst. Min. Metall., 81:B189-B197.

Shanks, W.C., III., Böhlke, J.K., Seal, R.R., II, 1995. Stable isotopes in midocean ridge hydrothermal systems: interactions between fluids, minerals, and organisms. In Humphris, S.E., Zierenberg, R.A., Mullineaux, L.S., 
Thompson, R.E. (Eds.), Seafloor Hydrothermal Systems: Physical, Chemical, Biological, and Geological Interactions. Geophys. Monogr., 91:194-221.

Shanks, W.C., III, and Seyfried, W.E., Jr., 1987. Stable isotope studies of vent fluids and chimney minerals, southern Juan de Fuca Ridge: sodium metasomatism and seawater sulfate reduction. J. Geophys. Res., 92:11387-11399.

Shikazono, N., Holland, H.D., and Quirk, R.F., 1983. Anhydrite in Kuroko deposits: mode of occurrence and depositional mechanisms. Econ. Geol. Monogr., 6:329-344.

Skirrow, R., and Coleman, M.L., 1982. Origin of sulfur and geothermometry of hydrothermal sulfides from the Galapagos Rift, $86^{\circ} \mathrm{N}$. Nature, 299:142-144.

Smith, D.K., and Cann, J.R., 1990. Hundreds of small volcanoes on the median valley floor of the Mid-Atlantic Ridge at $24^{\circ}-30^{\circ} \mathrm{N}$. Nature, 348:152-155

Stakes, D.S., and O'Neil, J.R., 1982. Mineralogy and stable isotope geochemistry of hydrothermally altered oceanic rocks. Earth Planet. Sci. Lett., 57:285-304.

Stakes, D.S., and Taylor, H.P., Jr., 1992. The northern Samail Ophiolite: an oxygen isotope, microprobe, and field study. J. Geophys. Res., 97:70437080

Steefel, C.I., 1987. The Johnson River prospect, Alaska: gold-rich seafloor mineralization from the Jurassic. Econ. Geol., 82:894-914.

Thompson, G., Humphris, S.E., Schroeder, B., Sulanowska, M., and Rona, P.A., 1988. Active vents and massive sulfides at $26^{\circ} \mathrm{N}$ (TAG) and $23^{\circ} \mathrm{N}$ (Snakepit) on the Mid-Atlantic Ridge. Can. Mineral., 26:697-711.

Thompson, G., Mottl, M.J., and Rona, P.A., 1985. Morphology, mineralogy, and chemistry of hydrothermal deposits from the TAG area, $26^{\circ} \mathrm{N}$ MidAtlantic Ridge. Chem. Geol., 49:243-257.

Tivey, M.K., Humphris, S.E., Thompson, G., Hannington, M.D., and Rona, P.A., 1995. Deducing patterns of fluid flow and mixing within the TAG active hydrothermal mound using mineralogical and geochemical data. $J$. Geophys. Res., 100:12527-12555.
Tivey, M.A., Rona, P.A., and Schouten, H., 1993. Reduced crustal magnetization beneath the active sulfide mound, TAG hydrothermal field, MidAtlantic Ridge $26^{\circ}$ N. Earth Planet. Sci. Lett., 115:101-115.

Tuach, J., Dean, P.L., Swinden, H.S., O'Driscoll, C.F., Kean, B.F., and Evans, D.T.W., 1988. Gold mineralization in Newfoundland: a 1988 Review. Newfoundland Dep. Mines Energy, Geol. Surv. Branch, Rep., 89-1:279-306.

Varga, R.J., and Moores, E.M., 1985. Spreading structure of the Troodos ophiolite, Cyprus. Geology, 13:846-850.

Woodruff, L.G., and Shanks, W.C., 1988. Sulfur isotope study of chimney minerals and hydrothermal fluids from $21^{\circ} \mathrm{N}$, East Pacific Rise: hydrothermal sulfur sources and disequilibrium sulfate reduction. J. Geophys. Res., 93:4562-4572.

Wooldridge, A.L., Harrison, C.G.A., Tivey, M.A., Rona, P.A., and Schouten, H., 1992. Magnetic modeling near selected areas of hydrothermal activity on the Mid-Atlantic and Gorda ridges. J. Geophys. Res., 97:1091110926.

Zierenberg, R.A., Seyfried, W.E., Koski, R.A., and Strickler, M.D., 1988. Mineralization, alteration, and hydrothermal metamorphism of the ophiolite-hosted Turner-Albright sulfide deposit, southwestern Oregon. J. Geophys. Res., 93:4657-4674.

Zierenberg, R.A., Shanks, W.C., III., and Bischoff, J.L., 1984. Massive sulfide deposits at $21^{\circ}$, East Pacific Rise: chemical composition, stable isotopes, and phase equilibria. Geol. Soc. Am. Bull., 95:922-929.

Zonenshain, L.P., Kuzmin, M.I., Lisitsin, A.P., Bogdanov, Y.A., and Baranov, B.V., 1989. Tectonics of the Mid-Atlantic rift valley between the TAG and MARK areas $\left(26-24^{\circ} \mathrm{N}\right)$ : evidence for vertical tectonism. Tectonophysics, 159:1-23.

Date of initial receipt: 29 May 1996

Date of acceptance: 31 December 1997

Ms 158SR-217 